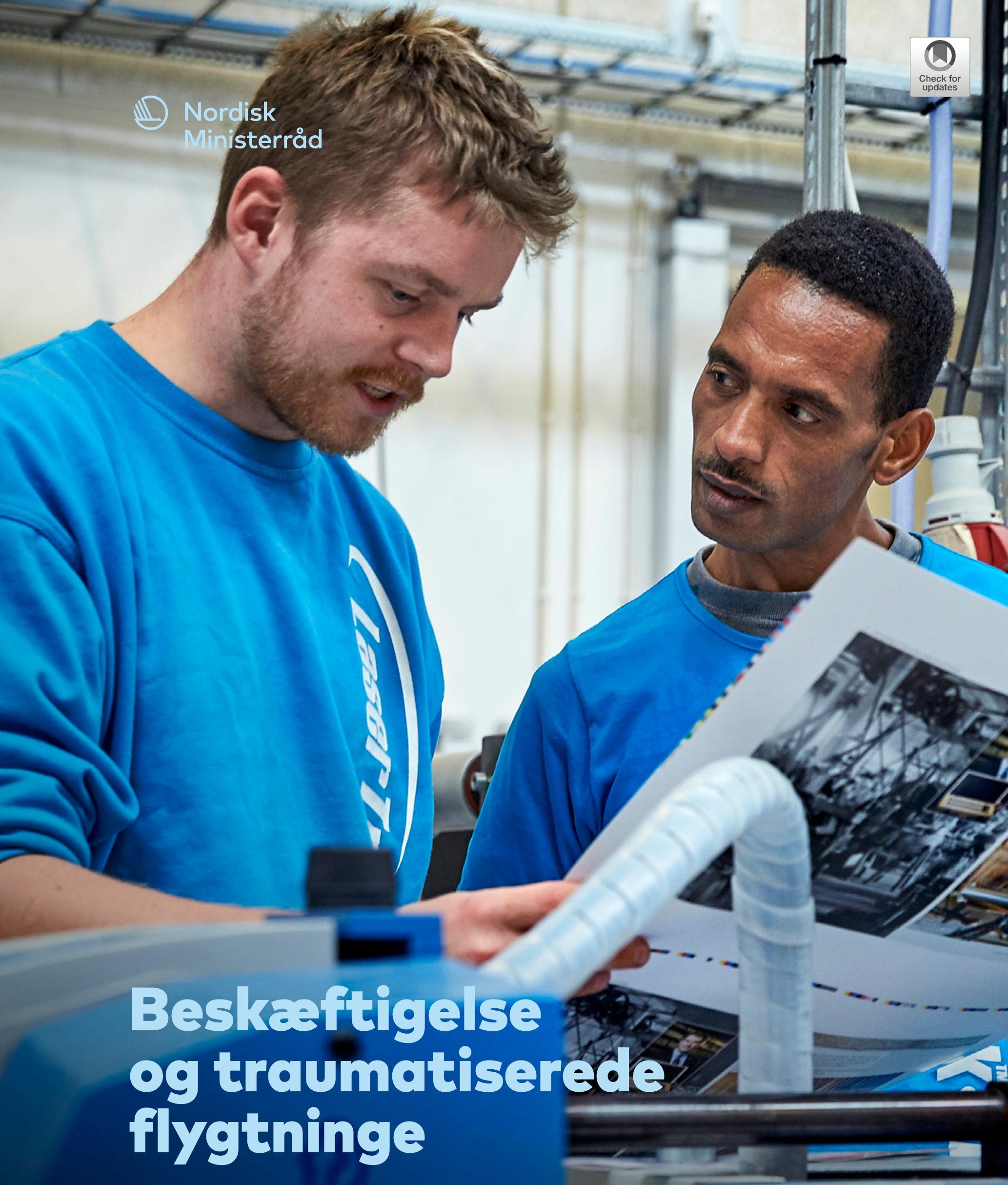

En undersøgelse af virkningsfulde beskæftigelsesindsatser for udsatte og traumatiserede flygtninge i de nordiske lande 



\section{Beskæftigelse og traumatiserede flygtninge}

En undersøgelse af virkningsfulde beskæftigelsesindsatser for udsatte og traumatiserede flygtninge i de nordiske lande

Anja Weber Stendal og Lisbeth Mørk Iversen

TemaNord 2019:520 
Beskæftigelse og traumatiserede flygtninge

En undersøgelse af virkningsfulde beskæftigelsesindsatser for udsatte og traumatiserede flygtninge i de nordiske lande

Anja Weber Stendal og Lisbeth Mørk Iversen, Center for Udsatte Flygtninge, Dansk Flygtningehjælp

ISBN 978-92-893-6094-4 (PRINT)

ISBN 978-92-893-6095-1 (PDF)

ISBN 978-92-893-6096-8 (EPUB)

http://dx.doi.org/10.6027/TN2019-520

TemaNord 2019:520

ISSN $0908-6692$

Standard: PDF/UA-1

ISO 14289-1

(c) Nordic Council of Ministers 2019

Omslagsfoto: Tony Brøchner / Dansk Flygtningehjælp

Tryk: Rosendahls

Printed in Denmark

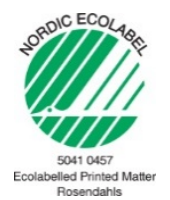

\section{Ansvarsfraskrivelse}

Denne publikation er finansieret af Nordisk Ministerråd. Indholdet afspejler dog ikke nødvendigvis Nordisk Ministerråds synspunkter, holdninger, anskuelser eller anbefalinger.

\section{Rettigheder og tilladelser}

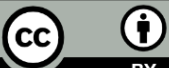

Dette værk er gjort tilgængeligt i henhold til Creative Commons Attribution 4.0 International License (CC BY 4.0) https://creativecommons.org/licenses/by/4.0

Oversættelser: Hvis du oversætter dette værk, bedes du inkludere følgende ansvarsfraskrivelse: Denne oversættelse er ikke produceret af Nordisk Ministerråd og skal ikke betragtes som officiel. Nordisk Ministerråd kan ikke drages til ansvar for oversættelsen eller eventuelle fejl, den måtte indeholde.

Bearbejdning: Hvis du bearbejder dette værk, bedes du inkludere følgende ansvarsfraskrivelse sammen med tilskrivelsen af værket: Dette er en bearbejdning af et originalt værk publiceret af Nordisk Ministerråd. Ansvaret for de synspunkter og holdninger, der kommer til udtryk i bearbejdelsen, påhviler udelukkende forfatteren/forfatterne til bearbejdningen. Synspunkter og holdninger i denne bearbejdning er ikke godkendt af Nordisk Ministerråd. 
Tredjepartsindhold: Nordisk Ministerråd er ikke nødvendigvis ejer af samtlige dele af dette værk. Nordisk Ministerråd kan derfor ikke garantere, at genbrug af tredjepartsindhold ikke udgør en overtrædelse af en tredjeparts ophavsret. Hvis du ønsker at genbruge tredjepartsindhold, bærer du selv ansvaret for enhver overtrædelse af ophavsretten. Du er ansvarlig for at vurdere, om det er nødvendigt at indhente en tilladelse til anvendelse af tredjepartsindhold og i så fald at indhente den nødvendige tilladelse fra ophavsretsindehaveren. Eksempler på tredjepartsindhold inkluderer, men er ikke begrænset til, tabeller, illustrationer og billeder.

Fotorettigheder (genbrug kræver yderligere tilladelse):

Alle henvendelser vedrørende rettigheder og licenser skal stiles til:

Nordisk Ministerråd/PUB

Ved Stranden 18

1061 København K

Telefonnr. 33960200

pub@norden.org

Det nordiske samarbejde

Det nordiske samarbejde er en af verdens mest omfattende regionale samarbejdsformer. Samarbejdet omfatter Danmark, Finland, Island, Norge og Sverige samt Færøerne, Grønland og Åland.

Det nordiske samarbejde er både politisk, økonomisk og kulturelt forankret, og er en vigtig medspiller i det europæiske og internationale samarbejde. Det nordiske fællesskab arbejder for et stærkt Norden i et stærkt Europa.

Det nordiske samarbejde ønsker at styrke nordiske og regionale interesser og værdier i en global omverden. Fælles værdier landene imellem er med til at styrke Nordens position som en af verdens mest innovative og konkurrencedygtige regioner.

\section{Nordisk Ministerråd}

Nordens Hus

Ved Stranden 18

1061 København K

www.norden.org

Download nordiske publikationer: www.norden.org/nordpub 



\section{Indhold}

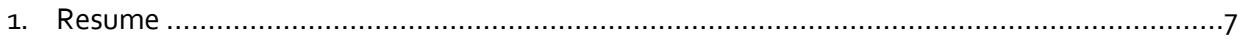

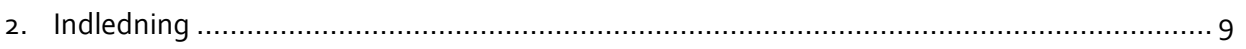

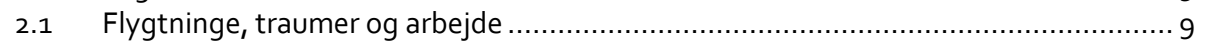

2.2 Traumer, eksilforhold og komplekse situationer .............................................

2.3 At lære fra nordiske nabolande..............................................................

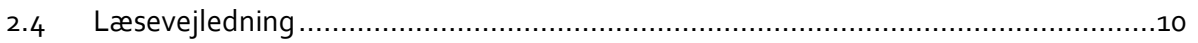

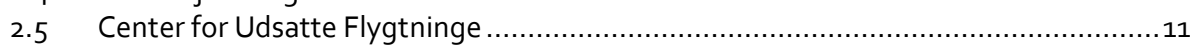

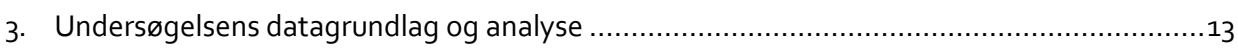

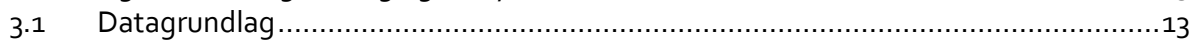

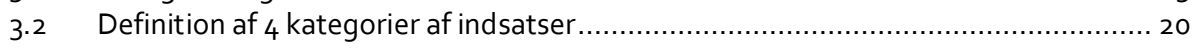

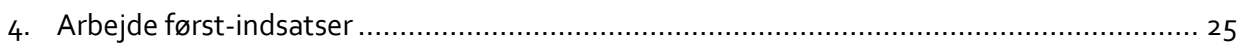

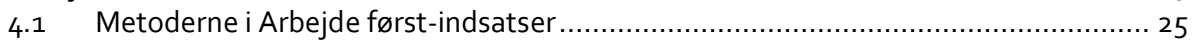

4.2 Vidensgrundlag i litteraturstudiet for Arbejde først-indsatser .............................27

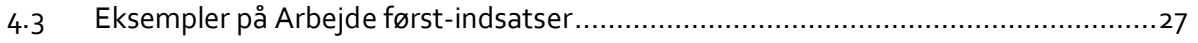

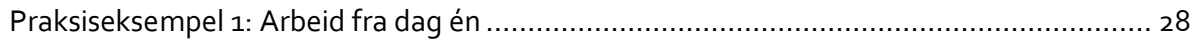

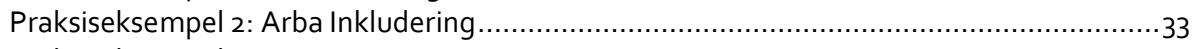

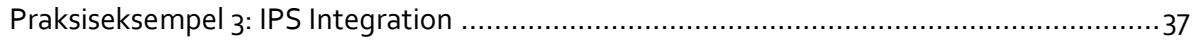

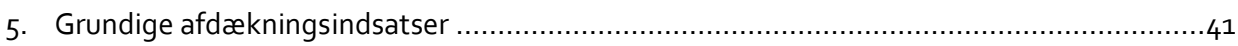

5.1 Metoder i arbejdet med Grundige afdækningsindsatser ..................................41

5.2 Vidensgrundlag i litteraturstudiet for Grundige afdækningsindsatser .................. 42

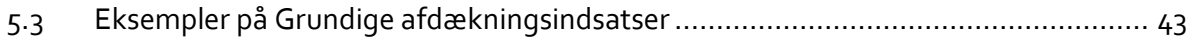

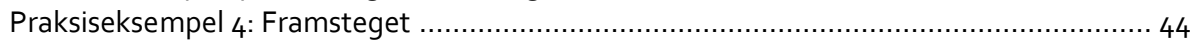

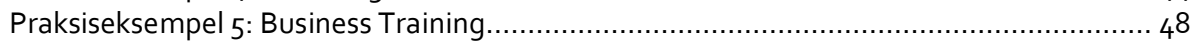

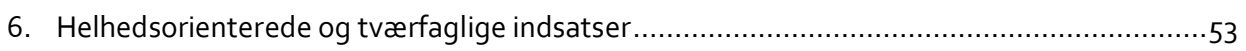

$6.1 \quad$ Metoder i Tværfaglige og helhedsorienterede indsatser ...................................53

6.2 Vidensgrundlaget i litteraturstudiet for Helhedsorienterede og

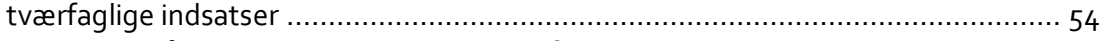

6.3 Eksempler på Helhedsorienterede og tværfaglige indsatser ................................57

Praksiseksempel 6: Hela Familjen 2.0.................................................................... 58

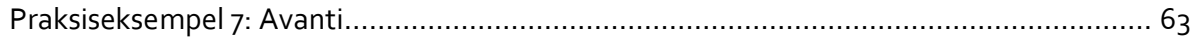

7. Indsatser baseret på en empowerment-tilgang .....................................................67

7.1 Metoderne i Indsatser baseret på en empowerment-tilgang .............................67

7.2 Vidensgrundlag i litteraturstudiet for Indsatser baseret på en

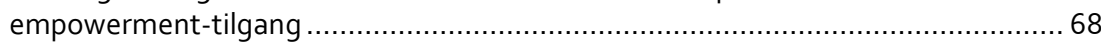

7.3 Eksempler på Indsatser baseret på en empowerment-tilgang ..................................68

Praksiseksempel 8: VAMOS - Trail of Involvement of Immigrant Youth ............................69

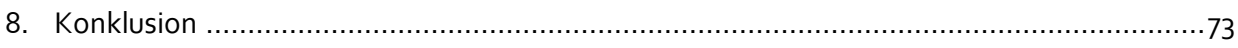

8.1 Forudsætninger for virksomme beskæftigelsesindsatser .................................. 74

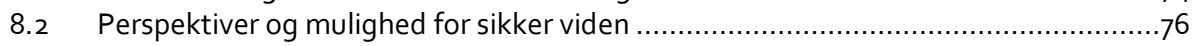

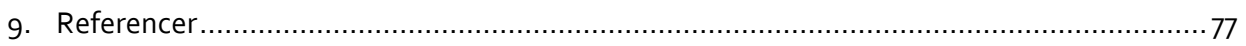

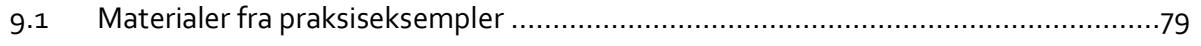

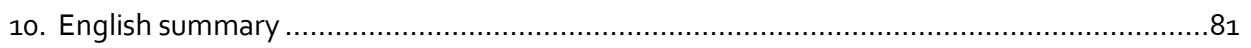

Bilag 1. Sådan er undersøgelsen gennemført .......................................................... 83

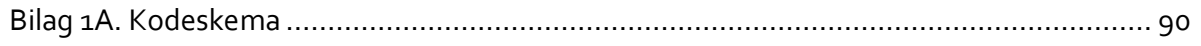

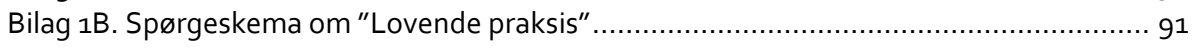

Bilag 2: Beskæftigelsesindsats for flygtninge i Reykjavik, Island ....................................105 


\section{Resume}

Rapporten formidler resultaterne af en undersøgelse af virkningsfulde beskæftigelsesindsatser for flygtninge og familiesammenførte til flygtninge, der er psykisk sårbare, har symptomer på traumer eller er traumatiserede. Undersøgelsen består af et litteraturstudie og en afdækning af eksisterende praksisser for målgruppen i Danmark, Finland, Island, Norge og Sverige. Undersøgelsen er gennemført i 2018 og omhandler litteratur fra perioden 2012 til 2018.

Undersøgelsen viser, at der er et begrænset vidensgrundlag om virkningsfulde beskæftigelsesindsatser for målgruppen. Der findes få studier af specifikke indsatser, og robustheden af studierne i forhold til at måle effekt er lav. Der er til gengæld identificeret en række lovende praksisser i Danmark, Finland, Norge og Sverige, der har god sandsynlighed for at have gode beskæftigelseseffekter for målgruppen. Medarbejdere og/eller ledere, der arbejder med de lovende praksisser, er interviewet af flere omgange. Der er er fyldige beskrivelser af otte praksiseksempler i rapporten.

Ud fra undersøgelsen er der defineret fire kategorier af virkningsfulde beskæftigelsesindsatser for målgruppen. Kategorierne er defineret ud fra de elementer, der bliver udpeget som særligt virkningsfulde i litteraturen og i praksiseksemplerne. Kategorierne er ikke gensidigt udelukkende, og elementer fra de forskellige kategorier kan eksistere sideløbende i en indsats. Der er dog klare forskelle imellem kategoriernes hovedfokus.

Arbejde forst-indsatser lægger vægt på opstart af ordinære timer så hurtigt som muligt og sideløbende træning, støtte og i nogle tilfælde behandling. Der arbejdes med reduceret og mere strategisk brug af praktik end i den normale beskæftigelsesindsats $i$ de nordiske lande. Arbejde først-indsatser er baseret på metoderne Supported Employment og Individual Placement and Support, hvor der foreligger høj grad af evidens for beskæftigelseseffekter for andre målgrupper. Indsatsen er baseret på deltagernes egen motivation og egne mål.

Grundige afdækningsindsatser er orienteret imod at afdække ressourcer, udfordringer og motivation hos deltagerne som grundlag for individuelt tilrettelagt forløb med beskæftigelses- og sundhedsorienteret støtte. Indsatserne har fokus på helhedsorienteret afdækning, og der anvendes konkrete afdækningsredskaber og sammensatte forløb i virksomheder til indsatsen.

Helhedsorienterede og tværfaglige indsatser arbejder med en koordineret og bredspektret støtte. Indsatserne i denne kategori er ofte rettet mod deltagere med komplekse udfordringer. Metoderne handler i høj grad om at støtte deltagerne både med arbejdsmarkedsrettede, sundhedsfaglige og sociale aktiviteter parallelt. Fokus er struktur og koordination og et blik for hele mennesket i indsatsen.

Indsatser baseret på en empowerment-tilgang er baseret på et særligt mindset, hvor deltagerne ses som, og styrkes i at være, handlekraftige aktører i eget liv. Gennem metoder, som eksempelvis coachende samtaler, styrkes deltagere i selv at definere egne mål 
og behov og i at blive aktive i forhold til at håndtere egen helbreds- og beskæftigelsessituation. Denne kategori indgår også som et delelement i de andre kategorier af indsatser.

På tværs af de inkluderede studier og praksisser i undersøgelsen er der nogle centrale forudsætninger for at lave virkningsfulde beskæftigelsesindsatser for målgruppen, der går igen.

- Investering er nødvendig og betaler sig. Alle praksiseksemplerne i undersøgelsen er funderet på en ekstra investering.

- Der skal være et nuanceret blik for individuelle behov $i$ indsatsen. Individuelt tilrettelagte forløb er mulige, fordi at medarbejderne i indsatserne har lavere sagstal og mere tid til rådighed til den enkelte deltager.

- Der er behov for længerevarende indsatser og efterværn. Litteratur og praksiseksempler illustrerer behovet for, at forløbene er relativt lange og kontinuerlige - også efter opnået ansættelse.

- Arbejdet kræver grundlæggende tro på målgruppens muligheder. Metode er ikke alt. En tværgående konklusion er, at det er nødvendigt med medarbejdere $\mathrm{i}$ indsatsen, der tror på, at målgruppen har en plads på arbejdsmarkedet.

Undersøgelsen viser et felt i udvikling. Flere af undersøgelsens praksiseksempler arbejder aktivt og målrettet med at synliggøre, at investering i deres indsats betaler sig og med at dokumentere deres resultater.

Beskæftigelsesresultaterne for praksiseksemplerne i Arbejde først-kategorien er meget gode. Det kan blandt andet skyldes, at målgruppen har mindre komplekse udfordringer, men taler også for, at der med fordel kan arbejdes med meget stringente metoder med fokus på det ordinære arbejdsmarked og reduceret anvendelse af praktik. Indenfor kategorien Arbejde først-indsatser er der også potentiale for at skabe sikker viden om beskæftigelseseffekter for målgruppen. I øjeblikket er der et randomiseret kontrolleret forsøg med metoden i gang for flygtning (med og uden traumer) $i$ Bergen. 


\section{Indledning}

Rapporten formidler viden om virkningsfulde beskæftigelsesindsatser for flygtninge og familiesammenførte til flygtninge, der betegnes som "psykisk sårbare, har symptomer på traumer eller er traumatiserede". Den bygger på en undersøgelse, der består af et større litteraturstudie og en praksisafdækning af eksisterende virkningsfulde beskæftigelsesindsatser for målgruppen i Danmark, Finland, Island, Norge og Sverige. Undersøgelsen er afgrænset til perioden 2012 til 2018. For en uddybende beskrivelse af undersøgelsens gennemførsel og metode henvises til Bilag 1.

Målgruppen for rapporten er beslutningstagere, ledere og medarbejder, der arbejder beskæftigelsesrettet med flygtninge.

I sin helhed giver rapporten et overblik over eksisterende viden og praksis inden for beskæftigelsesindsatser for flygtninge, der er psykisk sårbare eller har traumer. I undersøgelsen er virkningen af og dokumentation for de undersøgte beskæftigelsesindsatser vurderet systematisk. Ønsket er, at undersøgelsen dermed kan bidrage til at kvalificere og styrke eksisterende og nye indsatser for målgruppen.

Undersøgelsen viser en række eksempler på, hvordan flygtninge og familiesammenførte med symptomer på traumatisering integreres på et nordisk arbejdsmarked. Som læser kan man vælge at dykke ned i beskrivelser af tilgange og/eller enkeltstående praksiseksempler fra de nordiske lande og lære af deres konkrete erfaringer.

\subsection{Flygtninge, traumer og arbejde}

Der er gode grunde til at interessere sig for virkningsfulde metoder til at øge psykisk sårbare og traumatiserede flygtninges deltagelse på det nordiske arbejdsmarked. For det første er traumesymptomer og dårligt psykisk helbred hyppigt forekommende hos flygtninge i eksil. For det andet viser forskningen klare sammenhænge mellem arbejdsløshed og traumesymptomer såvel som dårligt psykisk helbred.

Omkring hver tredje flygtning i eksil er traumatiseret (LG Insight, 2013). I et studie af nyankomne flygtninge fra Syrien, Eritrea og Somalia i Sverige beskriver Röde Korsets Högskola, at cirka $30 \%$ lider af betydelige PTSD-symptomer og en tredjedel af angstsymptomer (Tinghög, P., Arwidson, C. and Sigvardsdotter, E. et al., 2016).

For den tredjedel af flygtningene, der har traumesymptomer, kan beskæftigelse medvirke til at øge deres trivsel. For flygtninge med traumer er der en sammenhæng mellem at være i beskæftigelse og at have et lavere symptomniveau (Johansen, 2008). På tværs af etnicitet og køn har manglende beskæftigelse stor negativ betydning for oplevelser af "psychological distress (red.: psykisk belastning)" (Sidorchuk A., Engström K. and Johnson CM et al., 2017). I det tidligere nævnte studie fra Röda Korsets Högskola er en af konklusionerne, at de som: "ofte har været frustrerede på grund af 
problemer med at forsørge sig selv (red.: oversat fra svensk til dansk)" har større forekomst af depression, angst og dårligt psykisk velbefindende (Tinghög, P., Arwidson, C. and Sigvardsdotter, E. et al., 2016, s. 34). Ovennævinte studier understreger, at et fokus på et hverdagsliv med selvforsørgelse som en væsentlig komponent kan reducere traumesymptomer og bidrage til bedre psykisk helbred.

\subsection{Traumer, eksilforhold og komplekse situationer}

Studierne bidrager også til en forståelse af traumatisering, hvor der ikke er et 1:1-forhold mellem at have oplevet traumatiske begivenheder og at få Post Traumatisk Stress Syndrom eller symptomer på traumatisering. Mange forskere peger på, at flygtningens livssituation i eksiltilværelsen har stor betydning for, hvorvidt man får varige symptomer på traumatisering.

Forskellige faktorer i eksiltilværelsen påvirker niveauet af traumesymptomer, blandt andet konkrete juridiske usikkerheder om ophold og familiesammenføring, men også bristede ambitioner, tab af status, manglende relationer til familie og manglende adgang til lokale fællesskaber (Warfa et al., 2012, Sveriges Kommuner och Landsting, 2015 og Shapiro, 2017). Beskæftigelse spiller sammen med de ovennævnte faktorer i eksiltilværelsen og kan påvirke både selvforståelse, status og sociale relationer.

De virkningsfulde indsatser, rapporten beskriver, arbejder med forskellige delmålgrupper, forskellige tilgange og lægger vægt på forskellige elementer. Alle deler de dog en forståelse for, at den enkelte flygtning og dennes eventuelle familie er i en kompleks situation, hvor eksilforhold og traumesymptomer gensidigt påvirker hinanden.

\subsection{At lære fra nordiske nabolande}

De nordiske lande, der er med i denne undersøgelse, har ikke identiske rammer for integrations- og beskæftigelsesindsatsen. Derfor vil det sjældent være muligt at lave indsatser, der i forhold til aktører, varighed, finansiering og elementer er fuldstændigt identiske i to nordiske lande.

Undersøgelsen fokuserer på de centrale virkningsfulde elementer i indsatserne, og praksisbeskrivelserne fokuserer derfor mindre på organisatoriske rammer og kontekst og mere på specifikke elementer og handlinger. Det styrker muligheden for at lære af eksemplerne, selvom man befinder sig i en anden organisatorisk kontekst.

\section{$2.4 \quad$ Læsevejledning}

Afsnit 3 giver et samlet overblik over undersøgelsens datagrundlag og analysen af den indsamlede viden fra litteraturstudiet og praksisafdækningen.

Afsnit 4-7 præsenterer fire kategorier af indsatser, der er defineret ud fra undersøgelsen. 
- Afsnit 4 omhandler Arbejde først-indsatser

- Afsnit 5 omhandler Grundige afdækningsindsatser

- Afsnit 6 omhandler Helhedsorienterede og tværfaglige indsatser

- Afsnit 7 omhandler Indsatser baseret på en empowerment-tilgang.

I hvert afsnit beskrives metoderne i indsatsen, vidensgrundlaget i litteraturstudiet, og der præsenteres praksiseksempler fra Norden.

Afsnit 8 er konklusionen på undersøgelsen og opsummerer centrale elementer i virkningsfulde beskæftigelsesindsatser for psykisk sårbare og traumatiserede flygtninge

Bilag 1 præsenterer undersøgelsens fremgangsmåde og metodiske grundlag.

Bilag 2 præsenterer beskæftigelsesindsatsen for flygtninge på Island gennem Reykjavik som eksempel.

\subsection{Center for Udsatte Flygtninge}

Denne undersøgelse er lavet af Center for Udsatte Flygtninge, et videnscenter, der er en del af Dansk Flygtningehjælp. Center For Udsatte Flygtninge har siden 1999 indsamlet og formidlet viden om flygtninge med traumer og andre særligt udsatte flygtninge. Undersøgelsen er delvist finansieret af Nordisk Ministerråd. Center for Udsatte Flygtninge er i forbindelse med undersøgelsens metodiske design blevet rådgivet af Didde Cramer Jensen fra VIVE - Det Nationale Forsknings- og Analysecenter for Velfærd.

Undersøgelsen har en hjemmeside, hvor der ligger videoklip og kortere tekster om undersøgelsens praksiseksempler: http://workandtrauma.org/

Spørgsmål til publikationen eller om beskæftigelsesindsatser for traumatiserede kan rettes til:

Center for Udsatte Flygtninge, telefon: +45 337553 39, e-mail: udsatte@drc.ngo 


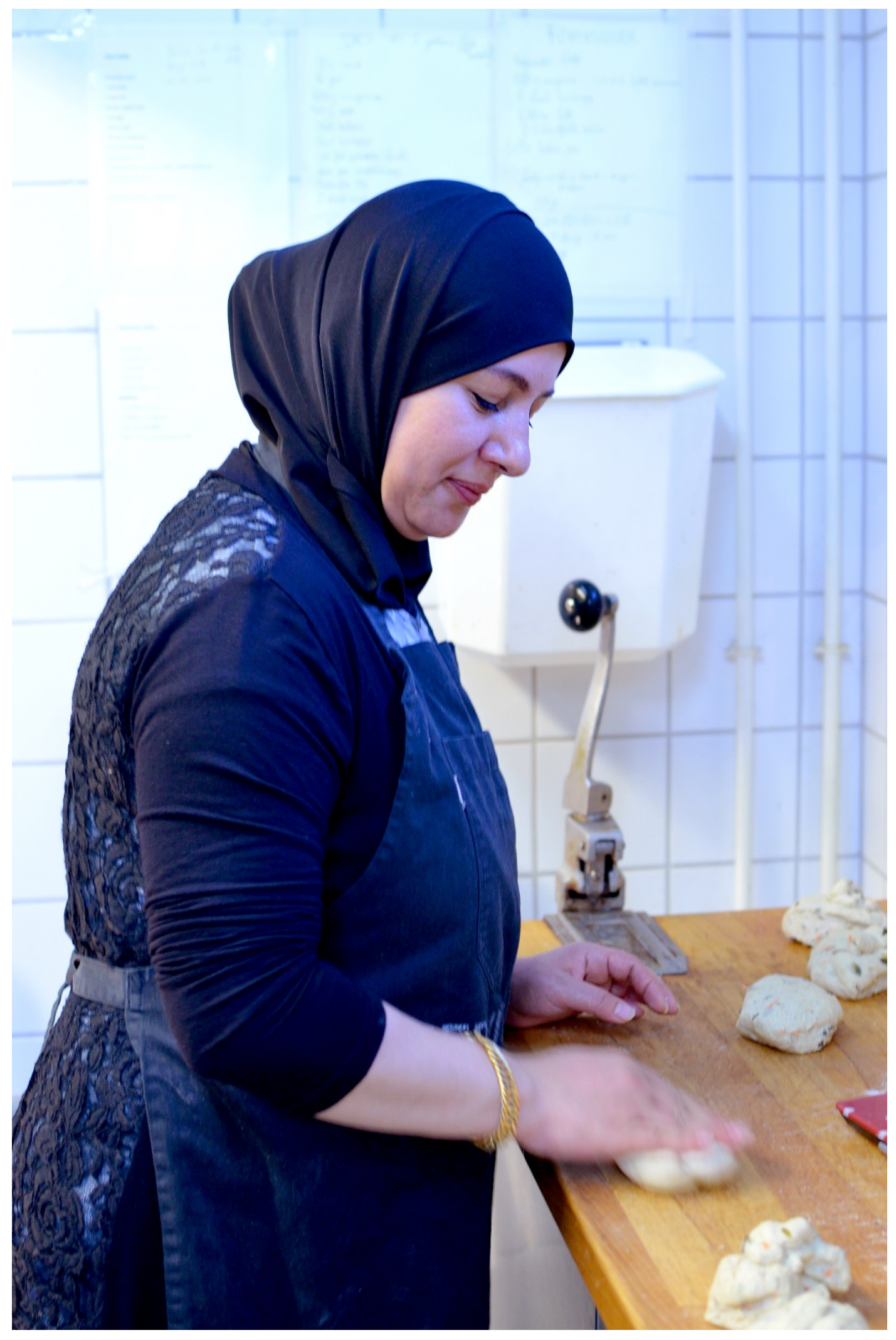




\section{Undersøgelsens datagrundlag og analyse}

Afsnittet giver et overblik over undersøgelsens datagrundlag, og hvordan vidensgrundlaget $i$ litteraturen og virkningen af indsatserne er vurderet. Afslutningsvis introduceres definitionen af de 4 kategorier af indsatser, der præsenteres i afsnit 4-7.

\subsection{Datagrundlag}

Samlet set viser undersøgelsen, at der er ganske få eksisterende indsatser og ganske få studier af indsatser i litteraturen, der både er beskæftigelsesrettede og omhandler målgruppen af traumatiserede flygtninge.

Der er gennemført en systematisk litteratursøgning i perioden fra 2012 til 2018. Litteratursøgningen har omfattet både forskningsdatabaser og grå litteratur, primært i form af rapporter og myndighedsudgivelser.

Praksisafdækningen er sket gennem afsøgning af relevante indsatser i Norden og strukturerede interviews over telefon samt besøg og dybdegående interview hos de udvalgte praksiseksempler. Enkelte af indsatserne er både repræsenteret i praksiseksemplerne og litteraturstudiet.

\subsubsection{Litteraturstudiet}

Litteratursøgningen omfattende 1668 referencer, hvoraf 16 er relevante for undersøgelsen. De 16 udvalgte referencer består hovedsageligt af grå litteratur. De 16 referencer er gennemlæst og vurderet med henblik på robustheden af deres dokumentation $\mathrm{i}$ forhold til at vurdere effekter af metoder og redskaber i beskæftigelsesindsatsen for psykisk sårbare og traumatiserede flygtninge.

Der er 6 studier, der beskriver specifikke interventioner for målgruppen, heraf 4 der beskriver den samme intervention. Robustheden af de 6 studiers metoder til at dokumentere effekter er vurderet på baggrund af Socialstyrelsens Vidensdeklaration: effektviden klassificering C-A. (Socialstyrelsen, 2017).

Studierne af de 3 specifikke interventioner for målgruppen er alle vurderet til C, det vil sige, at robustheden af studierne i forhold til at måle effekter er lav. Der kan dermed siges at være et lavt evidensgrundlag på området.

Interventionsstudierne er suppleret med referencer, der består af rapporter med mere generelle anbefalinger til indsatsen enten på baggrund af sammenligning af flere projekter, ekspertanbefalinger eller i et enkelt tilfælde på baggrund af randomiserede 
kontrollerede studier om indsatser for lignende målgrupper. Desuden indgår to referencer, der er publicerede kvalitative undersøgelser af målgruppens oplevelse af beskæftigelsesrettede indsatser. Disse erfaringer og anbefalinger er medtaget, fordi de vurderes at kunne bidrage til kvalificering af fremtidige indsatser på området.

Nedenfor ses en oversigt over den udvalgte litteratur og vurderingen af designets robusthed i forhold til at vurdere effekt (C-A) i den enkelte publikation.

Tabel 1: Oversigt over udvalgt litteratur og vurdering af effektviden

\begin{tabular}{ll|l|l} 
Reference $\quad$ Land & Beskrivelse af metodisk design & $\begin{array}{l}\text { Studiets } \\
\text { karakter }\end{array}$ & $\begin{array}{l}\text { Niveau af } \\
\text { effektviden }\end{array}$
\end{tabular}

Amilon, Anna (2017). IPS til flygtninge med traumerelaterede psykiske symptomer. Estimat af det forventede økonomiske udbytte. VIVE Det Nationale Forsknings- og Analysecenter for Velfærd.

Boll, Joachim, Damgaard, Pia og Høeberg, Lars (2014). Brug for alle. Kva litativ evaluering. Rambøll for Styrelsen for Arbejdsmarked og Rekruttering.

Bylin, Anna (2017). Slutrapportering till Finsam Sydnärke Projekt Framsteget.
DK Bylin, Anna (2015). Slutrapport Fö studien "Första Steget". Samordningsförbundet Sydnärka.

COWI (2018): Business Training. Midtvejsevaluering. Den Europæiske Union, Den Europæiske Socialfond. Den Europæiske Fond for Regionaludvikling.

Eastmond, Maria (2014). Refugee Trauma as mobilizing metaphor: Policy and practice in the integration and care of refugees in Sweden. In Overland, Gwynuth et al. Nordic Work with Traumatised refugees: Do We Really Care. Cambridge Scholars Publishing. 2014
DK Business Case-beregning for en IPS-indsats for flygtninge med traumesymptomer baseret på et projektforslag og eksisterende evidens for metoden IPS for lignende målgrupper.

Kvalitativ slutevaluering af "brug for alle"-initiativ. Indsatsen er rettet mod 30.000 personer. Evaluering baseret på forandringsteori foretaget blandt andet gennem casebesøg, survey med 913 deltagere og 396 sagsbehandlere. Traumatiserede flygtninge er en delmålgruppe, og resultaterne er ikke udskilt for gruppen.

SE Evaluering af konkret projektindsats, hvor flygtninge med PTSD er en delmålgruppe. Resultatmåling efter projekt samt evaluering af implementering.

SE

Afdækning af flygtninge med PTSD og/eller funktionsnedsættelses behov gennem interview med fagprofessionelle og kortlægning af tidligere projekters resultater.

\section{Grå} litteratur (notat)

Grå litteratur (Evalueringsrapport)

Grå litteratur (Evalueringsrapport) Grå litteratur (Rapport)

Grå litteratur hvor flygtninge med traumer er en delmålgruppe. Implementeringsstudie med kvalitative interviews og resultatopgørelse.

(Evalueringsrapport)

Etnografisk studie. Data indhentet blandt 300 bosniere og professionelle i kommuner og sundhedscentre. Omhandler oplevelser af integrationsproces og beskæftigelsesindsatser, men er ikke indsatsspecifik. 


\begin{tabular}{|c|c|c|c|c|}
\hline Reference & Land & Beskrivelse af metodisk design & $\begin{array}{l}\text { Studiets } \\
\text { karakter }\end{array}$ & $\begin{array}{l}\text { Niveau af } \\
\text { effektviden }\end{array}$ \\
\hline $\begin{array}{l}\text { Eriksson Sjöö, Tina (2014). Samver- } \\
\text { kansteam för personer med PTSD- } \\
\text { liknande symtom. Vid Arbetds- } \\
\text { marknad- och vuxenutbildningför- } \\
\text { valtningen, Göteborg. Slutrapport. } \\
\text { Samordningsförbundet Göteborg } \\
\text { Nordost. }\end{array}$ & SE & $\begin{array}{l}\text { Afrapportering på projekt omhandlende } \\
\text { behov, muligheder og forhindringer for } \\
\text { arbejdet med personer med PTSD i ar- } \\
\text { bejdsmarkedsrettede indsatser og sprog- } \\
\text { undervisning. Baseret på kvalitative in- } \\
\text { terviews med fagpersoner og målgruppe. }\end{array}$ & $\begin{array}{l}\text { Grå } \\
\text { litteratur } \\
\text { (Rapport) }\end{array}$ & \\
\hline
\end{tabular}

\begin{abstract}
FINSAM (2014). PTSD-Center. Rapport Juni 2014.

Försäkringskassan och Arbetsförmedlingen (2016). Nyanländas rehabiliteringsbehov. Arbetssätt och verktyg för att identifiera behov och förslag till utvecklingsområden. ESFprojekt. Förstudie. 2016
\end{abstract}

Gullers group (2015). Utvärdering av Finsamprojektet PTSD-Center.

Jansson, Björn og Wiren, Mårten (2016). Utvärdering av Finsamprojektet PTSD-Center. TJP Analys och Utveckling

LG Insight (2013). Traumeundersøgelse. Undersøgelse af indsatsen for flygtninge med traumer i Danmark. September 2013. Social-, Børne- og Integrationsministeriet

Norling, Urban (2015). Samverkande Framgångfaktorer. Fremgångsrika insatser och organiseringar kring utlantsfödda med omfattande samordnade rehabiliteringsbehov. Föreningen NNS Rapportserie 2015:3

Pooremamali, P., Persson, D., Östman, M. og Eklund, M.(2015). Facing Challenges during Occupation: Middle Eastern Immigrants' Paths to Occupational Well-Being in Sweden. Journal of Occupational Science, 2015, 22:2, 228-241.
SE

Kvalitativ evaluering af PTSD-Centret, der er et konkret projekt for flygtninge med PTSD og migrationsrelateret stress. Evaluering er baseret på spørgeskema og fokusgruppe- og enkeltinterviews med

medarbejdere og deltager.

SE

vering af PTSD-Centret, der er et og migrationsrelateret stress. Evaluerin gen er baseret på resultatmåling samt fokusgruppeinterview.

SE Forstudie. Kortlægning af eksisterende værktøjer til at afdække nyankomnes dårlige helbred samt metoder, der kan muliggøre deres indtræden på arbejdsmarkedet. Rapporten er baseret på fokusgruppeinterviews, studiebesøg og spørgeskemaer.

Evaluering af PTSD-Centret, der er konkret projekt for flygtninge med PTSD og migrationsrelateret stress. Evalueringen er baseret på resultatmåling og kvalitativ undersøgelse.

Undersøgelse af indsatser for traumatise rede flygtninge, herunder beskæftigelsesrettede indsatser. Baseret på spørgeskemaundersøgelse hos 96 kommuner og kvalitative interview med 45 kommunale aktører samt udvalgte eksperter og professionelle.

SE Kortlægning af virksomme indsatser i forhold til at støtte udlandsfødte med komplekse problemer, for eksempel dårlig psykisk helse i at komme på eller tættere på arbejdsmarkedet. Undersøgelsen bygger på identifikation af løsningsmodeller i eksisterende og tidligere indsatser gennem sneboldssampling.

SE Kvalitativ undersøgelse af en gruppe mellemøstlige flygtninge med psykiske lidelsers oplevelser af arbejdsmarkedsindsatser i Sverige. Baseret på grounded theory.

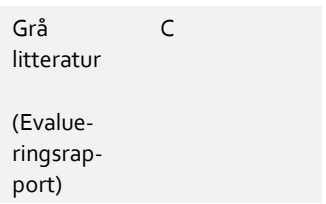

Grå

litteratur

(Rapport)

Grå

C

litteratur

(Evalue-

ringsrap-

port)

Grå

litteratur

\section{(Evalue-}

ringsrap-

port)

Grå

litteratur

(Rapport)

Grå

litteratur

(Rapport)

Forskning

(Publiceret

artikel) 


\begin{tabular}{|c|c|c|c|c|}
\hline Reference & Land & Beskrivelse af metodisk design & $\begin{array}{l}\text { Studiets } \\
\text { karakter }\end{array}$ & $\begin{array}{l}\text { Niveau af } \\
\text { effektviden }\end{array}$ \\
\hline $\begin{array}{l}\text { Vilhelmsson, A., Östergren PO., } \\
\text { Bjørngren Cuandra, Carin (2015). } \\
\text { Hälsa i Centrum för Etableringspro- } \\
\text { cessen. Bedömning av arbets- och } \\
\text { prestationformåga inom etable- } \\
\text { ringen av nyanlända. FOU-rapport } \\
\text { 2015. Malmö Högskola }\end{array}$ & SE & $\begin{array}{l}\text { Slutrapport baseret på et delprojekt i } \\
\text { MILSA 2. Rapporten er baseret på fore- } \\
\text { læsnings- og seminarrækker og følge- } \\
\text { forskning tilknyttet udvikling af praksis i } \\
\text { arbejdsformidlingen i } 4 \text { kommuner. }\end{array}$ & $\begin{array}{l}\text { Grå } \\
\text { litteratur } \\
\text { (Rapport) }\end{array}$ & \\
\hline $\begin{array}{l}\text { Widerberg, Tobias (ansvarlig). Slut- } \\
\text { rapport Finsam.PTSD-Center 2015- } \\
\text { 2017. Arbetsmarknads- och socialför- } \\
\text { valtningen. }\end{array}$ & SE & $\begin{array}{l}\text { Slutrapport om PTSD-Centret, der er et } \\
\text { konkret projekt for flygtninge med PTSD } \\
\text { og migrationsrelateret stress. Evaluerin- } \\
\text { gen består af resultatopgørelse og sam- } \\
\text { menstilling af erfaringer. }\end{array}$ & $\begin{array}{l}\text { Grå } \\
\text { litteratur } \\
\text { (Evalue- } \\
\text { ringsrap- } \\
\text { port) }\end{array}$ & C \\
\hline
\end{tabular}

Kilde:

Egen opgørelse over vidensgrundlaget $\mathrm{i}$ indsamlet litteratur. Niveauer af effektviden er vurderet ud fra Socialstyrelsens Vidensdeklaration: effektviden klassificering A-C. (Socialstyrelsen. 2017). 


\subsubsection{Praksisafdæekningen}

De besøgte indsatser er udvalgt, fordi de (helt eller delvist) beskæftiger sig med psykisk sårbare og/eller traumatiserede flygtninge, fordi de er beskæftigelsesrettede, og fordi de gennem et interview baseret på et måleredskab (struktureret spørgeskema) har vist sig at have en lovende praksis.

Der er udvalgt praksiseksempler fra alle de deltagende lande med undtagelse af Island, der ikke havde en beskæftigelsesindsats rettet specifikt mod traumatiserede flygtninge. I bilag 2 er en beskrivelse af Islands generelle beskæftigelsesindsats over for flygtninge illustreret gennem indsatsen i Reykjavik.

Måleredskabet, som undersøgelsen anvender, hedder "Lovende praksis". Det er udviklet af SFI - Det Nationale Forskningscenter for Velfærd til det specialiserede socialområde og spørger til 11 elementer, som forskningen viser har betydning for, om en praksis er virkningsfuld. Det er tilpasset en smule i denne kontekst, men vurderet relevant at anvende til beskæftigelsesrettede praksisser.

Formålet med interviews baseret på måleredskabet er at vurdere, hvor fagligt velfunderet og vidensbaseret indsatsen er, for dermed at sandsynliggøre, om indsatsen virker og kan øge beskæftigelsen for målgruppen. At have en lovende praksis vil sige, at indsatsen har en række elementer og kendetegn, der øger sandsynligheden for, at praksissen har den forventede beskæftigelseseffekt for målgruppen. Nedenstående figur viser de 11 elementer, som kan fremme en virkningsfuld praksis, fordelt inden for fire hovedområder.

Figur 1: Model for lovende praksis

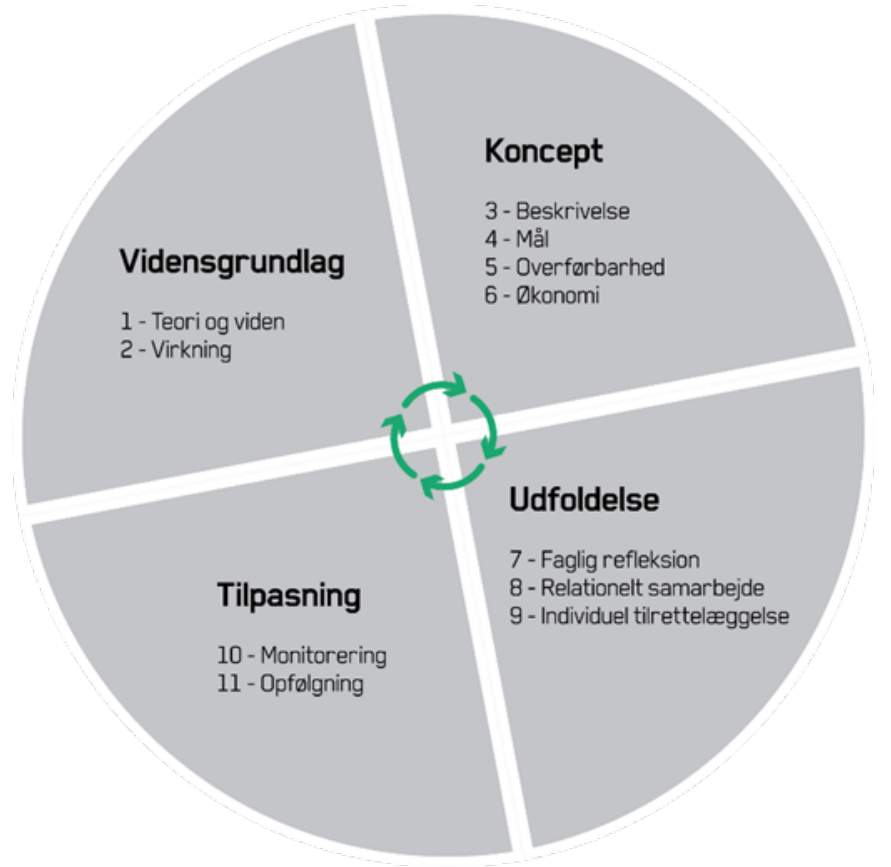

Kilde:

Cramer Jensen, D., Jin Pedersen, M., Hyld Pejtersen, J. og Amilon A., 2016, s. 36. 
På basis af måleredskabet er der beregnet en score for hver af de besøgte praksisser (se Tabel 2). Den maksimale score, en indsats kan opnå, er 11. Alle de besøgte praksisser har en relativ høj score og derfor en høj sandsynlighed for at have en beskæftigelseseffekt for målgruppen.

Tabel 2: Indsatserne vurderet med måleredskabet for "Lovende praksis"

\begin{tabular}{lr} 
Arba Inkludering (NO) & 7,98 \\
Arbeid fra dag én (NO) & 8,21 \\
Avanti (SE) & 9,04 \\
Business Training (DK) & 9,21 \\
Framsteget (SE) & 8,18 \\
Hela Familjen 2.0 (SE) & 9,14 \\
IPS Integration (DK) & 9,79 \\
VAMOS - Trail of Involvement for Immigrant Youth (FI) & 6,78 \\
\hline
\end{tabular}

Kilde: Egne beregninger ud fra måleredskabet "Lovende praksis" udviklet af det tidligere SFI.

Scoren varierer dog fra lige under 7 til næsten 10, så der er væsentlige forskelle på, hvor lovende indsatserne er. Variationen skyldes blandt andet bevidst forskellige tilgange i de undersøgte praksisser, som eksempelvis at den finske indsats "VAMOS - Trail of Involvement for Immigrant Youth" aktivt vælger at reducere mængden af dokumentation og opfølgning på progression for at skabe rum for det personlige møde. Det giver dem en lavere score i forhold til blandt andet monitorering og opfølgning.

Variationen skyldes også, at indsatserne bygger på forskellig teori og viden. Flere af de indsatser, der scorer højest, baserer sig på beskæftigelsesmetoder, hvor der foreligger evidens for metoden, dog testet for andre målgrupper. Det styrker deres score både i forhold til at beskrive teori og vidensgrundlag, men også effekter og selve konceptet for indsatsen. Det gælder eksempelvis den danske indsats "IPS Integration".

\subsubsection{Lovende praksis, målgruppe og resultater}

Vurderingen af, hvor lovende en praksis er, giver et godt indblik i indsatserne, men ikke det fulde billede. Dette afsnit anskueliggør, hvad vi ved om beskæftigelsesresultaterne af de besøgte indsatser, hvilke målgrupper de enkelte indsatser beskæftiger sig med og deres varighed. Informationerne om praksisserne er opsummeret i Tabel 3.

Hovedparten af de besøgte praksisser er ikke afsluttede, og der foreligger derfor ikke endelig dokumentation for resultaterne. Dokumentationen er heller ikke ensartet: Nogle har foretaget interne eller eksterne evalueringer, andre har egne statusmålinger. Desuden har nogle af indsatserne målt resultater for en målgruppe, hvor udsatte flygtninge kun er en delmængde, mens andre indsatser har målt resultater specifikt for udsatte flygtninge. Endelig varierer deltagerantallet $\mathrm{i}$ indsatserne fra omkring 20 til flere hundrede. 
Der er også store forskelle på karakteren af indsatsernes målgrupper. En væsentlig forskel er målgruppens ledighedsperiode. Nogle indsatser er rettet mod nyankomne og andre mod langtidsledige. Eksempelvis retter den norske indsats "Arbeid fra dag én" sig mod nyankomne, hvorimod den svenske "Hela Familjen 2.0" er et tilbud til langtidsledige familier, hvor flygtningegruppen vil have været minimum 4 år i Sverige.

Kravene til målgruppens sprogkundskaber varierer også mellem indsatserne. Nogle indsatser arbejder eksplicit med målgrupper, der har behov for tilpasset sprogundervisning på grund af vanskeligheder med at tilegne sig værtslandets sprog, eksempelvis den svenske "Avanti". Andre indsatser kræver et sprogligt minimumsniveau, for at man kan deltage i indsatsen, eksempelvis den norske "Arba Inkludering".

Der er forskel på hvor mange og hvor udtalte traumesymptomer, deltagerne i indsatserne har. I danske "Business Training" er de stærkest traumatiserede ikke en del af målgruppen. I svenske "Avanti" og "Hela Familjen 2.0" er der deltagere med PTSD-diagnoser, som modtager tværfaglig behandling.

Endelig er der også markante forskelle på indsatsernes varighed, som både er defineret af de rammer og muligheder, der er i det pågældende land, og i nogle tilfælde tilpasset tidsbegrænsede projektmidler. Indsatsernes varighed har i nogle tilfælde betydning for, hvor gode beskæftigelsesresultater der kan opnås. I andre tilfælde kan det have betydning for varigheden af indsatsen, at deltagerne før opstart har været igennem andre mere forberedende indsatser. 


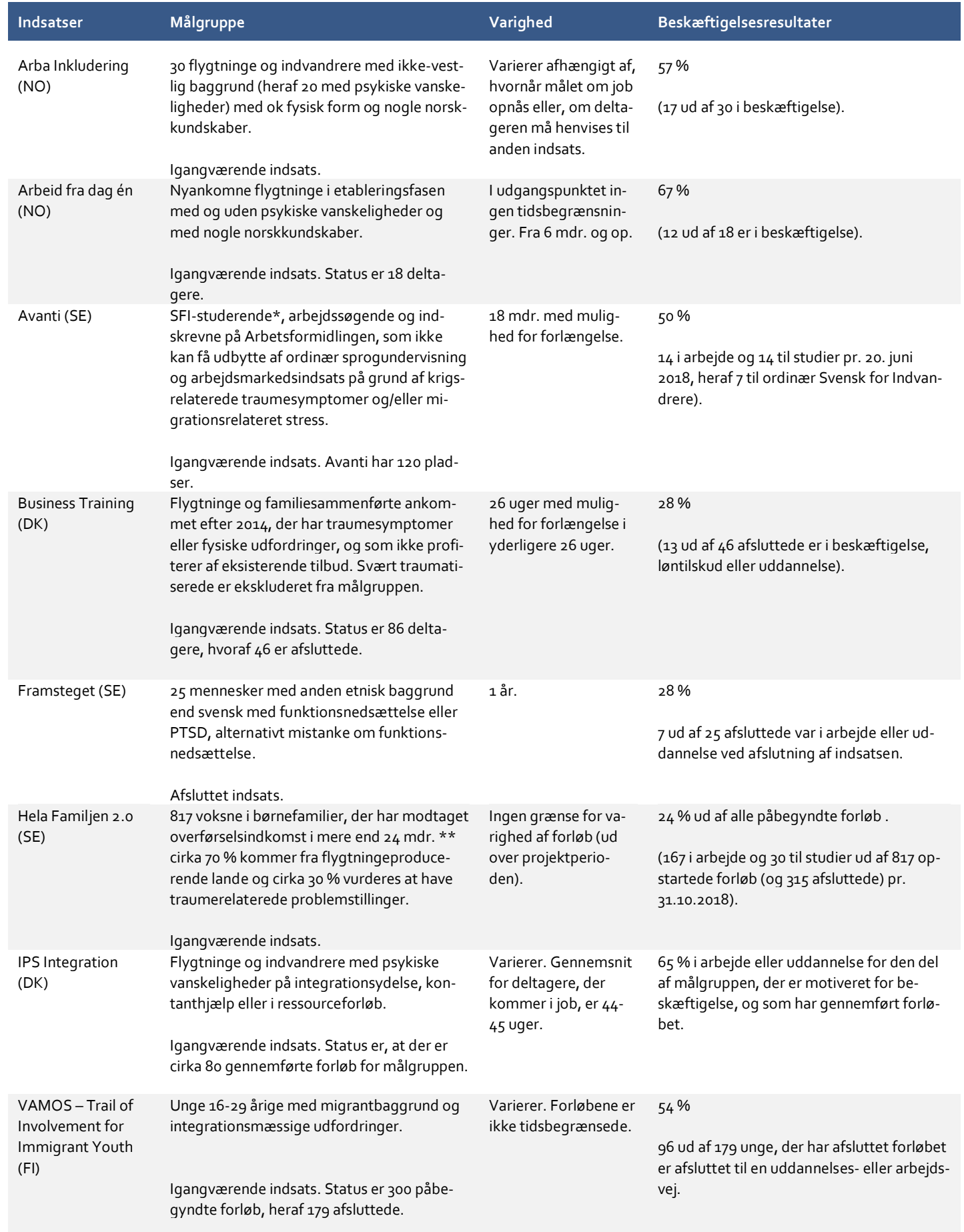

Note: * $\quad$ Studerende, der læser Svensk For Indvandrere (SFI)

** For flygtninge vil det reelt være i 4 år, da de 24 mdr. først tæller efter integrationsperioden på 2 år.

Kilde: Er baseret på indsatsernes egne beskrivelser. 


\subsection{Definition af 4 kategorier af indsatser}

Afsnit 4 til 7 formidler resultatet af undersøgelsen. Den undersøgte litteratur og de undersøgte nordiske praksisser er opdelt i fire kategorier baseret på deres kerneelementer. Kerneelementet er det delelement $\mathrm{i}$ indsatsen, der betragtes som mest afgørende for, at indsatsen har en virkning for målgruppen. For enkelte af studierne har det ikke været muligt at udskille et kerneelement, fordi alle elementer i de anvendte metoder har været vurderet som lige vigtige.

Datagrundlaget har givet anledning til følgende fire kategorier:

- Arbejde først-indsatser

- Grundige afdækningsindsatser

- Helhedsorienterede og tværfaglige indsatser

- Indsatser baseret på en empowerment-tilgang.

Kategorierne er ikke nødvendigvis gensidigt udelukkende. Der er dog klare forskelle:

Arbejde først-indsatser lægger vægt på en hurtig opstart af ordinære timer. Indsatserne har fokus på værdien af at genoprette det "normale " hverdagsliv gennem selvforsørgelse og på, hvordan det at arbejde og deltage i det sociale liv i sig selv har en rehabiliterende effekt for traumatiserede. I nogle af indsatserne foregår der koordination med behandlingssystemet, men i andre indgår der ikke sundhedsorienterede indsatser på systematisk vis.

Grundige afdækningsindsatser lægger vægt på en grundig kortlægning af ressourcer, kompetencer og udfordringer som udgangspunkt for individuelt tilrettelagte forløb med arbejdsmarkedsrettet støtte og eventuel behandling. Der er fokus på, hvordan afdækningen bør omfatte flygtninges helbredsforhold og samlede livssituation.

Helhedsorienterede og tværfaglige indsatser vægter tværfaglighed, koordination og parallelle tilbud, hvor der både er arbejdsmarkedsrettede, sundhedsfaglige og sociale aktiviteter sideløbende. Indsatserne har fokus på behandling af traumet, som en del af vejen til at kunne fungere i arbejde og socialt liv.

Indsatser baseret på en empowerment-tilgang har fokus på det enkelte individs ønsker og behov som defineret af individet selv for aktivt at imødegå, at indsatserne bidrager til at offer- eller klientgøre deltagerne. Empowerment kan indgå som element $\mathrm{i}$ andre typer indsatser. Der er dog i denne kategori også udvalgt et praksiseksempel, der tilbyder et alternativ til de tilbud, der er forankret i offentligt regi.

I Tabel 4- 7 ses en samlet oversigt over kategorierne og de kerneelementer fra litteratur og praksiseksempler, de er defineret på baggrund af.

I Afsnit 4 til 7 beskrives hver kategori, vidensgrundlaget i den udvalgte litteratur, og hvordan man konkret kan arbejde inden for den enkelte kategori gennem praksiseksempler fra de nordiske lande. 
Tabel 4: Kategorien Arbejde først-indsatser - Oversigt over kategorier, kerneelementer, litteratur og indsatser

\begin{tabular}{ll|l}
\hline Kerneelement & Indsatser & Litteratur \\
\hline Systematisk brug af SE* & Arbeid fra dag én & \\
$\begin{array}{l}\text { Systematisk brug af IPS* og } \\
\text { to-kulturelle medarbejdere }\end{array}$ & IPS Integration \\
$\begin{array}{l}\text { Tæt og forpligtende } \\
\text { virksomhedssamarbejde }\end{array}$ & Arba Inkludering & \\
$\begin{array}{l}\text { IPS fremfor standard beskæftigelses- } \\
\text { indsats for flygtninge kan betale sig* }\end{array}$ & Amilon, 2017 \\
\hline
\end{tabular}

Note: *Systematisk brug af SE og IPS er ikke at betragte som et kerneelement, men som anvendelsen af en hel metode. I begge indsatser og i det ene studie har det været umuligt at udskille enkelte dele af metoden, der er mere virksomme end andre.

Kilde: Egen analyse af kerneelementer i indsatser og litteratur.

Tabel 5: Kategorien Grundig afdækningsindsatser - Oversigt over kategorier, kerneelementer, litteratur og indsatser

\begin{tabular}{|c|c|c|}
\hline Kerneelement & Indsatser & Litteratur \\
\hline $\begin{array}{l}\text { Grundig kortlægning af ressourcer, } \\
\text { støttebehov og interesser hos den en- } \\
\text { kelte deltager }\end{array}$ & Framsteget & Bylin, 2017 \\
\hline $\begin{array}{l}\text { Behov for individuelt tilrettelagt } \\
\text { støtte og forløb }\end{array}$ & & Bylin, 2015 \\
\hline $\begin{array}{l}\text { Helhedsorienteret afklaring gennem } \\
\text { individuelt tilrettelagte praktikforløb }\end{array}$ & Business Training & COWI, 2018 \\
\hline $\begin{array}{l}\text { Behov for tidlig opsporing af } \\
\text { helbredsproblemer }\end{array}$ & & $\begin{array}{l}\text { Vilhelmson, Östergren og Cuadra, } \\
2015 \text { og Norling, } 2015\end{array}$ \\
\hline $\begin{array}{l}\text { Behov for omfattende kortlægning af } \\
\text { livs- og familiesituation (i etablerings- } \\
\text { fasen) }\end{array}$ & & Eriksson Sjöö, 2014 \\
\hline
\end{tabular}

Kilde: Egen analyse af kerneelementer $\mathrm{i}$ indsatser og litteratur. 
Tabel 6: Kategorien Helhedsorienterede og tværfaglige indsatser - Oversigt over kategorier, kerneelementer, litteratur og indsatser

\begin{tabular}{|c|c|c|}
\hline Kerneelement & Indsatser & Litteratur \\
\hline Koordination og helhedssyn & Hela Familjen 2.0 & \\
\hline $\begin{array}{l}\text { Helhedssyn og tværfagligt samar- } \\
\text { bejde om deltagernes individuelle } \\
\text { planer }\end{array}$ & AVANTI & $\begin{array}{l}\text { Finsam, 2014, Gullers Group, 2015, } \\
\text { Jansson og Wiren, 2016, Widerberg, } \\
2017\end{array}$ \\
\hline $\begin{array}{l}\text { Tværfaglighed kan øge kvalitet og ef- } \\
\text { fekt }\end{array}$ & & Boll, Damgaard og Høeberg, 2014 \\
\hline $\begin{array}{l}\text { Tværfaglige indsatser bør bygge på } \\
\text { eksisterende strukturer }\end{array}$ & & Norling, 2015 \\
\hline $\begin{array}{l}\text { Øget behov for samarbejde mellem } \\
\text { sundheds- og arbejdsmarkedsaktører }\end{array}$ & & $\begin{array}{l}\text { Försäkringskassan och Arbetsförmed- } \\
\text { lingen, } 2016\end{array}$ \\
\hline $\begin{array}{l}\text { Ønske om øget tværfagligt samar- } \\
\text { bejde }\end{array}$ & & LG Insight, 2013 \\
\hline $\begin{array}{l}\text { Behov for at tænke arbejde bredere } \\
\text { som meningsfulde aktiviteter og in- } \\
\text { volvere civilsamfundet }\end{array}$ & & $\begin{array}{l}\text { Vilhelmson, Östergren og Cuadra, } \\
2015\end{array}$ \\
\hline
\end{tabular}

Kilde: Egen analyse af kerneelementer i indsatser og litteratur.

Tabel 7: Kategorien Indsatser baseret på en empowerment-tilgang - Oversigt over kategorier, kerneelementer, litteratur og indsatser

\begin{tabular}{lll} 
Kerneelement & Indsatser & Litteratur \\
\hline $\begin{array}{l}\text { Indflydelse på egne mål og planer } \\
\begin{array}{l}\text { Coaching baseret på den unges selv- } \\
\text { definerede behov }\end{array}\end{array}$ & $\begin{array}{l}\text { Norling, 2015 } \\
\text { Boll, Damgaard og Høeberg, 2014 } \\
\text { migrant Youth }\end{array}$ \\
$\begin{array}{l}\text { Behov for at bygge indsats på flygt- } \\
\text { ninges egne oplevelser og selvforstå- } \\
\text { else }\end{array}$ & Eastmond, 2014 \\
$\begin{array}{l}\text { Oplevelse af, hvad empowerment er, } \\
\text { præges af kulturbaggrund }\end{array}$ & Pooremamali, Östman, og Eklund, \\
\hline
\end{tabular}

Kilde: Egen analyse af kerneelementer i indsatser og litteratur. 


\section{Arbejde først-indsatser}

Kategorien Arbejde først-indsatser består hovedsageligt af igangværende indsatser baseret på metoderne Supported Employment og Individual Placement and Support. Kategorien er defineret på baggrund af nedenstående praksiseksempler og litteratur:

Tabel 8: Kategorien Arbejde først-indsatser

\begin{tabular}{lll}
\hline Kerneelement/ Hele metoder & Praksiseksempler & Litteratur \\
\hline Systematisk brug af SE* & Arbeid fra dag én & \\
$\begin{array}{l}\text { Systematisk brug af IPS og } \\
\text { to-kulturelle medarbejdere * }\end{array}$ & IPS Integration \\
$\begin{array}{l}\text { Tæt og forpligtende } \\
\text { virksomhedssamarbejde }\end{array}$ & Arba Inkludering & \\
$\begin{array}{l}\text { IPS fremfor standard-beskæftigelses- } \\
\text { indsats for flygtninge kan betale sig* }\end{array}$ & Amilon, 2017
\end{tabular}

Note: * Systematisk brug af SE og IPS er ikke at betragte som et kerneelement, men som anvendelsen af en hel metode. I begge indsatser og i det ene studie har det været umuligt at udskille enkelte dele af metoden, der er mere virksomme end andre.

Kilde: Egen analyse af kerneelementer $\mathrm{i}$ indsatser og litteratur.

\subsection{Metoderne i Arbejde først-indsatser}

Supported Employment og Individual Placement and Support er metoder til arbejdsmarkedsintegration, hvor fokus er på, at deltagere kommer hurtigt ud på arbejdspladsen uden brug af "træningsbaner", men med tæt og individuel, sideløbende støtte. Grundtanken er, at deltagere i indsatsen skal i arbejde først og oplæres og trænes sideløbende - beskrevet som place-then-train. Arbejde er i denne sammenhæng forstået udelukkende som ordinært arbejde på fuld eller deltid. Metoderne tager udgangspunkt i den enkelte deltagers egen motivation og ønsker for beskæftigelse.

Supported Employment-metoden anvendes traditionelt til integration af mennesker med handikap eller funktionsnedsættelser på arbejdsmarkedet. Individual Placement and Support er en variant af Supported Employment rettet mod deltagere med psykiske lidelser. Der foreligger en høj grad af evidens (i form af talrige randomiserede kontrollerede forsøg) for Individual Placement and Supports positive beskæftigelseseffekter for mennesker med svære psykiske lidelser, såsom skizofreni og depression (Drake RE, Bond $G R$, Becker DR, 2012). En forskningsoversigt fra Norge vurderer, at Individual Placement and Support på baggrund af den eksisterende forskning har samme positive beskæftigelseseffekter på det europæiske arbejdsmarked (Nøkleby H., Blaasvær N. og Berg R.C., 
2017). Der findes et enkelt forsøg med Individual Placement and Support for mennesker med PTSD - men uden flygtningebaggrund, der har givet positive beskæftigelsesresultater sammenlignet med normalindsatsen (Davis et al., 2012).

Supported Employment er en metode, der har været arbejdet med i Europa siden slutningen af 8o'erne. I regi af EU er der arbejdet med Supported Employment i European Union of Supported Employment, der blev grundlagt i 1993 (European Union of Supported Employment, 2010). I Norge er Supported Employment en større politisk satsning hos NAV (Nye Arbeids- og Velferdsetaten), den norske Arbeids- og velferdsforvaltningen. Supported Employment er baseret på 5 trin.

Boks 1: Supported Employment

Fem trin i Supported Employment

- Indledende kontakt og samarbejdsaftale.

- Jobkortlægning og karriereplanlægning.

- Finde et passende job.

- Samarbejde med arbejdsgiver for at udvikle og vedligeholde job.

- Oplæring og træning på eller uden for arbejdspladsen.

Kilde: European Union of Supported Employment, 2010.

Individual Placement and Support er en manualbaseret metode, der bygger på otte principper. Et af de udvalgte praksiseksempler arbejder ud fra de otte principper og manualen. Andre bygger på nogle af principperne, men kombinerer med andre metoder og/eller tilpasser principperne.

Boks 2: Individual Placement and Support

IPS-principper

- Alle, der ønsker at arbejde, kan deltage.

- Målet er beskæftigelse på det ordinære arbejdsmarked.

- IPS-indsatsen er integreret med den psykiatriske behandling.

- Deltagerne modtager vejledning i social- og beskæftigelseslovgivningen.

- Jobsøgningen starter hurtigt efter opstart i IPS-indsatsen.

- IPS-konsulenterne opbygger relationer til arbejdsgivere i lokalområdet, baseret på deltagernes ønsker om beskæftigelse.

- Den individualiserede støtte på arbejdspladsen er tidsubegrænset.

- Indsatsen er baseret på deltagernes ønsker og præferencer.

Kilde: Nationalt Netværk IPS. 


\subsection{Vidensgrundlag i litteraturstudiet for Arbejde først-indsatser}

Der er endnu ingen afsluttede studier af effekten af Arbejde først-indsatser for traumatiserede flygtninge. Én reference i litteraturstudiet underbygger relevansen af at arbejde med arbejde først-tilgange også til denne specifikke målgruppe. Det er en business case-beregning, der viser, at der kan være økonomiske fordele ved at igangsætte IPS-indsatser for målgruppen.

Amilon 2017 er en beregning af gevinsterne ved at igangsætte IPS-indsats til traumatiserede flygtninge fremfor den standard-beskæftigelsesindsats, der tilbydes i kommunerne i Danmark. Beregningen er baseret på eksisterende evidensbaserede studier af IPS for målgrupper, der minder mest om traumatiserede flygtninge, og kontekster, der er sammenlignelige med det danske arbejdsmarked. Resultatet af beregningen er, at tilbydes indsatsen til 50 mennesker, vil det offentlige over en periode på 36 måneder have en besparelse på 4,8-5,3 mio. ved at tilbyde IPS fremfor standard-beskæftigelsesindsatsen (Amilon, 2017).

Boks 3: Systematisk afprøvning af Supported Employment for flygtninge i Bergen

Et forsøg, der løber til 2020

Afdækningen af eksisterende praksis viste også et randomiseret kontrolleret forsøg i Bergen i Norge, hvor Supported Employment bliver systematisk afprøvet over for flygtninge - med og uden traumesymptomer. Forsøget løber fra 2017 til 2020 og kan følges her:

https://clinicaltrials.gov/ct2/show/record/NCT03629366

\subsection{Eksempler på Arbejde først-indsatser}

Tre af undersøgelsens udvalgte praksiseksempler tilhører denne kategori: Den danske indsats "IPS Integration", der varetages af Human Recovery, og de to norske indsatser "Arba Inkludering" og "Arbeid fra dag én" i Bærum Kommune.

Beskæftigelsesresultaterne fra de udvalgte praksiseksempler er gode og ligger mellem 57 og $67 \%$. Målingerne af effekter er baseret på indsatsernes egne opgørelser.

Praksiseksemplerne i denne kategori er baseret på metoder, hvor der foreligger evidens for effekter over for andre målgrupper. "Arbeid fra dag én" og "IPS Integration" eksemplificerer på forskellig vis, hvordan man kan arbejde med et stort fokus på metode - på basis af manualer eller gennem løbende supervision i forhold til metodetrofasthed. De to projekter arbejder med henholdsvis hele Supported Employment-metoden og hele Individual Placement and Support-metoden, og de har ikke kunne udskille ét virksomt element, som de øvrige indsatser. Derfor er beskrivelsen fokuseret på hele deres indsats.

På grund af det store fokus på ordinært arbejde i indsatserne er der også inspiration til, hvordan man arbejder med opbygning af relationen til virksomheder, reduceret og bevidst brug af praktikker og relevant opfølgning og opkvalificering på virksomheden. 


\section{Praksiseksempel 1: Arbeid fra dag én}

\section{Arbeid fra dag én}

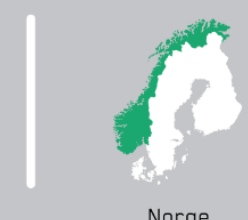

Norge

Aktører

Flyktningkontoret i Bærum Kommune og NAV (Arbeids- og velferdsforvaltningen).

\section{Kontaktperson}

Camilla Bildsten, tjenesteleder,Bærum Kommune, Flyktningkontoret, e-mail: camilla.bildsten@baerum.kommune.no, telefon: +4791598591

Formål

Deltagerne kommer i ordinært arbejde eller uddannelse.

Målgruppe for indsats

Alle flygtninge i Introduktionsprogrammet i Bærum kommune, der har nogle norskkundskaber og er motiverede (se visiteringskrav nedenfor).

Antal deltagere med traumer $\mathrm{i}$ indsats

18 deltagere, hvoraf et ikke specificeret antal har psykiske vanskeligheder.

\section{Varighed af indsats}

Indsatsen er ikke tidsbegrænset, men begrænset af introduktionsprogrammets varighed. Introduktionsprogrammet varer i op til to år, men kan forlænges med endnu et år, hvis det for eksempel vil styrke den enkeltes mulighed for at komme i arbejde eller ordinær uddannelse.

\section{Baggrund og resultater}

Arbeid fra dag én er en integreret del af introduktionsprogrammet for flygtninge i Bærum Kommune. Introduktionsprogrammet er målrettet flygtninge mellem 18 og 55 år og har blandt andet til formål at styrke deres deltagelse i erhvervslivet og selvforsørgelse. Arbeid fra dag én startede op i august 2017 med henblik på at tilbyde Supported Employment (SE) til flygtninge og dermed styrke deres muligheder for at opnå og fastholde ordinær beskæftigelse. Projektet har ikke en slutdato, men evalueres løbende og har gode resultater. Hvor længe det fortsætter, vil afhænge af dokumenterede resultater, kommunale og statslige bevillinger og politisk velvilje.

Grundholdningen i projektet er, at alle, der ønsker et job, skal få et tilbud. Der er en tro på, at alle, der vil, også kan. Projektet handler ikke om, at alle skal så hurtigt som muligt ud i job, men om at tænke langsigtet og finde noget, jobansøgerne brænder for. 
Dermed vil de stå på en mere fast grund, hvis der opstår problemer med at fastholde jobbet senere hen. Arbejdet med SE i introduktionsprogrammet for flygtninge bidrager til at udfordre den mere traditionelle tankegang om, at flygtninge skulle bruge to år på afklaring og sproguddannelse før, de kunne komme i arbejde (train then place). Nu ændres fokus til, at de forskellige indsatser skal ses som parallelle processer (place then train). Dette er et fokusskift, der betyder, at der også internt i kommunen er behov for, at en del af personalet får ændret deres mindset i forhold til, hvordan arbejdet med flygtningene skal foregå.

For at blive visiteret til projektet skal flygtningene have sprogfærdigheder på et niveau, hvor de som minimum kan forstå og udveksle informationer om velkendte ting (minimum A2), motivation for at komme i arbejde og evne til at arbejde selvstændigt. Optimalt set kan visitering til SE-indsatsen ske efter ni måneder i introduktionsprogrammet, men typisk bliver flygtningene først optaget efter ét til halvandet år.

Arbeid fra dag én gennemføres i et tværfagligt samarbejde mellem Flyktningkontoret og NAV, men er primært finansieret af Bærum Kommune, som er initiativtager til projektet

Samarbejdet og rollefordelingen mellem de forskellige interessenter udvikles løbende, efterhånden som projektet giver erfaringer, og behov for justeringer bliver synlige. Fra 1. september 2018 er projektet opnormeret.

Resultatet efter det første år er, at $67 \%$ af de flygtninge, der har modtaget en SEindsats, og er vurderet til at tilhøre målgruppen, er i job (12 ud af 18). I starten af projektperioden blev der henvist nogle flygtninge til projektet, som efterfølgende viste sig ikke at have tilstrækkelige helbredsmæssige eller sproglige forudsætninger for at gennemføre forløbet (syv ud af 25). Disse blev visiteret tilbage til andre tilbud og tæller ikke med i statistikken. Efterfølgende er projektet blevet skarpere på målgruppen, og flygtninge, der ikke opfylder optagelseskriterierne, får andre tilbud, der matcher deres individuelle behov.

\section{Arbejdet med kerneelementet}

Arbeid fra dag én arbejder stringent med SE-metoden og kan ikke udpege ét kerneelement, der er mere virksomt end andre. Der arbejdes systematisk efter de fem trin i SE, og SE-værktøjskassen benyttes (European Union of Supported Employment, 2010). En jobspecialist fra Nav udfører arbejdet. Der arbejdes med en meget bevidst brug af praktik og med metodisk vejledning udført af en medarbejder i NAV. Projektet beskriver sit arbejde med de fem principper i SE på følgende måde:

1. Samarbejdsaftale med arbejdssøgeren: Ud fra en fælles forståelse planlægges vejen videre, og hvordan samarbejdet skal foregå. 
2. Karrierevejledning: Her udvikles en fælles forståelse af karrieren, deltagerens ønske og muligheder.

Her laves en karriereplan, der indeholder oplysninger om jobønske, branche, geografisk område, forventet timetal, helbred, uddannelses- og erhvervserfaring, mulige delmål og fremgangsmåde. Deltagerens CV gennemgås og opdateres.

3. Kontakt med arbejdsgivere og jobsøgning: Her findes en virksomhed, der passer til vedkommende. Det essentielle i Arbeid fra dag én er at støtte deltagerne i at finde ordinært arbejde, gerne i lokalområdet. Aktuelt er der vækst i erhvervslivet, og arbejdsgiverne har brug for kvalificerede kandidater, hvilket er befordrende for mulighederne for at finde gode jobmatch.

Mulighederne på det ordinære arbejdsmarked tjekkes først, og kravene synliggøres for deltageren. Herefter kan det være, at jobmålet i karriereplanen skal justeres. Det er deltagerens ansvar at finde virksomheder, men ofte går deltageren og jobspecialisten på virksomhedsbesøg sammen den første gang. De kan også gå ud hver for sig for at kortlægge virksomheden og branchen. Den indledende kontakt handler om at afklare, om der er et jobmatch.

4. Samarbejde med arbejdsgiver.

Samarbejdet med virksomhederne er baseret på kendskab til og forståelse for deres behov og handler i høj grad om at skabe gode relationer til virksomhederne. Når der er indgået en aftale med en arbejdsgiver om et inkluderingsforløb, handler jobspecialistens tilbud til virksomhederne om tilgængelighed, tæt opfølgning baseret på relationsarbejde, et solidt kendskab til deltageren og adgang til supplerende foranstaltninger, hvis der viser sig at være behov for det.

5. Opfølgning over tid (cirka seks måneder)

Opfølgning finder sted inden for den første periode efter ansættelse og er både målrettet jobsøger og arbejdsgivere. Hvis en virksomhed oplever, at en deltager ikke lever op til kravene, arbejdes der på at løse problemerne. Hvis deltagerne oplever problemer på arbejdspladsen, som har betydning for deres engagement, opfordres de til åbenhed. Det optimale er, at de selv tager det op i forhold til arbejdsgiveren, men jobspecialisten kan også gøre det, hvis det er aftalt med deltageren på forhånd, og i mange tilfælde findes der en løsning på udfordringerne.

Den tid, hvor der kan se opfølgning, er ikke ubegrænset, og selvom der ikke er udmeldt et præcist perspektiv, sker der sjældent opfølgning ud over et halvt år. Virksomheder og deltagere får dog at vide, at de altid er velkomne til at henvende sig i til jobspecialisten, hvis der opstår et behov, også selvom vedkommende er udskrevet fra projektet.

Jobspecialisten arbejder med bevidst brug af praktik. Der sigtes i udgangspunktet mod, at praktikker er så korte som muligt, og der etableres kun praktikker, hvis der er et klart mål relateret til karriereplanen. For deltagere, der mangler kendskab til specifikke arbejdsområder, kan en praktik være en "jobsmakk" (red. snusepraktik), der varer mellem 
én dag og maksimalt en uge. Deltagere, der gerne vil kvalificere sig til et bestemt arbejdsområde, som de ikke har erfaring med i forvejen, vil typisk også kunne få bevilget en praktik, der i udgangspunktet er af en måneds varighed. Hvis gabet mellem kravene i en ønsket stilling og deltagerens kompetencer viser sig at være for stort til ansættelse inden for en overskuelig periode, kan løntilskud komme på tale.

En del virksomheder har en forventning om at indlede et samarbejde med en længerevarende praktik. Disse forventninger imødegår jobspecialisten ved at gå i dialog med virksomheden, hvis det vurderes, at pågældende deltager er på niveau med øvrige jobansøgere, som opnår ansættelse direkte - eller kan klare sig med en kortere praktik. Her er tale om en dialog og en forhandling, hvor det på den ene side spiller en rolle, hvor stor en risiko virksomheden tager, og på den anden side er vigtigt ikke at forlænge en deltagers vej til ordinært arbejde, hvis der ikke er behov for opkvalificering. Nogle gange oplever jobspecialisten at måtte opgive et virksomhedssamarbejde, hvis der eksempelvis insisteres på en indledende 6-ugers praktik.

Jobspecialisten skal have en tæt relation til virksomheden for at kunne samarbejde om tilpasning af forløb og job til deltageren. Den tætte relation giver mulighed for, at jobspecialisten kan få øje på helt nye behov i en virksomhed, end der oprindeligt var tænkt på, og som måske passer bedre til deltageren. I så fald bidrager relationen til, at der kan opstå nye muligheder for deltageren og måske endda vækst for virksomheden.

En integreret del af arbejdet med SE er at sikre løbende opfølgning på, hvordan man bruger metoden. Den opfølgning sker gennem møder mellem en metodevejleder og jobspecialist om jobspecialistens arbejde: Metodevejlederen følger systematisk op på projektets fremdrift og kvaliteten af jobspecialistens arbejde med metoden. Opfølgningen sker hver måned, hvor det gøres op, hvor mange der er startet op i tiltaget, hvor mange der er afsluttet, og hvad er de afsluttet til: job, uddannelse, andre tiltag, som passer bedre, behandling eller andet. Hver tredje måned gås der mere i dybden med metoden.

Dialogen mellem metodevejleder og jobspecialist handler mere om sparring end om kontrol og har bl.a. til formål at skabe en større bevidsthed om de processer, der har betydning for, at deltageren kommer i mål. I SE er det vigtigt at arbejde efter deltagerens ønske, og sparringen kan handle om, hvad der er næste skridt, og hvornår der er gjort nok.

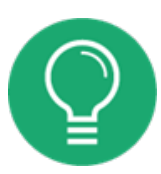

\section{Læringspunkter}

- SE i integrationsindsatsen giver dokumenterede resultater, hvilket er forudsætningen for fortsatte bevillinger og politisk velvilje.

- Implementeringen af SE i det ordinære integrationsprogram for flygtninge er en forandring, der kan mærkes i hele organisationen, og som fordrer et skift i mindset hos alle aktører i den offentlige forvaltning, der berøres af, at tidspunktet for inkluderingen af flygtningene i virksomhederne er rykket frem. 
- Det er individuelt, hvornår en flygtning er parat til at gå i gang med et SE-forløb. For eksempel skal flygtningen have et vist sprogligt niveau, og der kan for eksempel være helbredsmæssige barrierer, der skal tages hånd om først.

- Samarbejdet med virksomheden kræver ligeså mange ressourcer, som samarbejdet med deltageren.

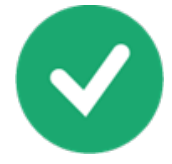

\section{Forudsætninger}

- Systematisk implementering af SE i integrationsindsatsen for flygtninge forudsætter politisk opbakning og nødvendige bevillinger.

- Klarhed i forhold til ejerskab, mål, rammer, roller og kompetencer for alle involverede og fokus på forandringsledelse.

- Rammer, der understøtter et tæt tværfagligt samarbejde mellem de berørte aktører.

- Rekruttering af medarbejdere med metodekendskab/ uddannelse af medarbejdere i metoden.

- Passende normering, der tager højde for, at der både skal være et tæt samarbejde med deltagere og virksomheder.

- Jobspecialister med godt kendskab til lokale virksomheder og deres behov samt alsidige konsulentkompetencer i forhold til empowerment, relationssalg, forhandling, med videre.

- Adgang til interne netværk i forvaltningen, som kan tage sig af ikke-jobrelaterede problemer hos deltagerne, så det ikke tager tid fra den jobrettede indsats.

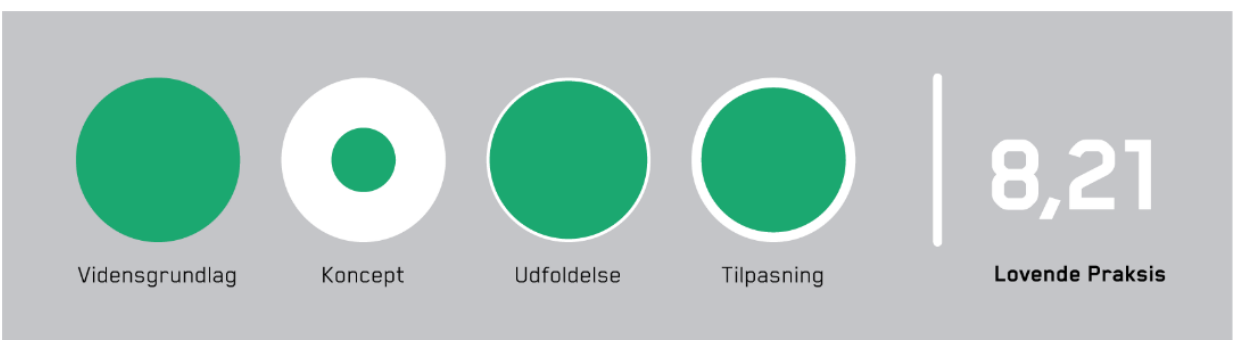




\section{Praksiseksempel 2: Arba Inkludering}

\section{Arba Inkludering}

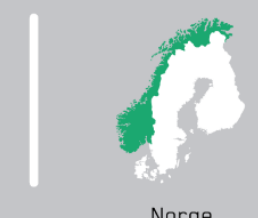

Norge

\section{Aktører}

Arba Inkludering AS, Ikea Slependen.

\section{Kontaktperson}

Lise Markant Kølbel, teamleder, arbeidsforberedende trening, Arba Inkludering AS,

telefon: +4795365527, e-mail: Iko@arba.no, www.arba.no | www.arbaformidling.no

Formål

Varig beskæftigelse for deltagere med behov for støtte til at få og fastholde arbejde.

\section{Målgruppe for indsats}

Ledige deltagere med nedsat funktionsevne, heraf 30 flygtninge og indvandrere, der er motiverede for at arbejde i lkea. Krav om rimelige norskkundskaber og ok fysisk helbred.

\section{Antal deltagere med traumer $\mathrm{i}$ indsats}

Der har deltaget 20 flygtninge/indvandrere med psykiske udfordringer, herunder traumer, i indsatsen.

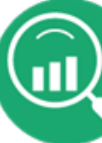

\section{Baggrund og resultater}

Praksisbeskrivelsen omhandler samarbejdet mellem Arba Inkludering og Ikea Slependen. Arba Inkludering arbejder med udgangspunkt i Supported Employment-tilgangen. Formålet med samarbejdet med lkea er afprøvning og indslusning af ledige med nedsat funktionsevne med henblik på, at de opnår og fastholder varigt arbejde. Et inkluderingsforløb indeholder følgende faser: afklaring, praktik, ansættelse - ofte på deltid med henblik på gradvis optrapning til fuldtid - og efterværn. Målet er ansættelse, og vejlederen hos Arba er katalysator for vejen dertil i et tæt samarbejde med deltageren og virksomheden.

Arba Inkludering er en førende aktør på beskæftigelsesområdet i Vestregionen i Akershus fylke (amt), som består af kommunerne Bærum og Asker. Arba Inkludering er ejet af Bærum kommune. Indsatsen finansieres af NAV (Arbeids- og Velferdsforvaltningen), der henviser til Arba Inkludering på baggrund af en behovs- eller arbejdsevnevurdering. 
Siden 2010 har 104 ledige med nedsat funktionsevne deltaget i et inkluderingsforløb i Ikea Slependen, og 67 har været i forløb mere end fire uger. Heraf har 52 fået forskellige kontrakter som for eksempel heltid, deltid, ekstrahjælp eller vikar, og 16 er afsluttet til andet job eller uddannelse. Der har deltaget 30 relativt nyankomne flygtninge/indvandrere i forløbet, heraf 20 med psykiske udfordringer. 17 ud af de 30 har opnået ansættelse i lkea.

\section{Arbejdet med kerneelementet}

Kerneelementet $\mathrm{i}$ indsatsen er et tæt og forpligtende virksomhedssamarbejde. Arbejdet varetages af én kontaktperson, der yder støtte og laver opfølgning. Opfølgningen finder sted før, under og efter inkluderingsforløbet.

Alle inkluderingsforløb på Ikea koordineres af en vejleder fra Arba, som også er fast kontaktperson i virksomheden. En vellykket inkludering forudsætter et tæa samarbejde mellem deltager, vejleder og virksomhed under hele forløbet. For vejlederen stiller det krav til løbende relationsarbejde i forhold til både deltager og virksomhed. Vejlederen leverer både vejledning til deltagere under indslusning og sparring til lkea og understøtter dialogen mellem deltager og virksomhed i de individuelle forløb. Deltageren kan deltage i sideløbende støtte efter behov - for eksempel sprogundervisning eller helbredsudredning - og den ugentlige arbejdstid tilpasses de samlede aktiviteter. Hvis der viser sig at være behov for yderligere afklaring undervejs, kan vejlederen henvise til det. Vejlederen vurderer indledningsvis deltagerens norskkundskaber, motivation og forventninger i forhold til at magte og fuldføre et inkluderingsforløb, der fører til ansættelse, og - på baggrund af en helbredsmæssig afklaring - om deltageren vil kunne klare jobbet. Hvis deltageren vurderes til at have potentiale til at blive ansat i lkea, sættes forløbet i gang, og deltageren påbegynder sin praktik i lkea. Hvis det under forløbet bliver klart, at deltageren ikke vil kunne indfri kravene til ansættelse på trods af støtten, standes det.

Vejlederens rolle i forhold til deltageren er at introducere til virksomheden og dens værdier og tydeliggøre virksomhedens krav og forventninger til sine ansatte. Vejlederen skal støtte deltageren i at søge job i lkea på baggrund af konkrete opslag, "oversætte" informationer fra virksomheden til de ansatte til et sprog, deltageren forstår herunder mundtlige informationer på personalemøder og stillingsbeskrivelser - foretage konkret individuel opfølgning og tilrettelægge relevante træningsaktiviteter efter behov på baggrund heraf.

Vejlederen har et indgående kendskab til virksomheden, arbejdsopgaver, krav og værdier. Det gør, at træningen og udviklingen af deltageren bliver meget konkret og arbejdsrelevant. Introduktionsarbejdet handler blandt andet om at gøre jobsøgeren fortrolig med lkeas værdier. Vedkommende bliver for eksempel bedt om at vælge en værdi ud, som de særligt interesserer sig for, og gå i dybden med dens betydning for 
vedkommendes egne handlinger på arbejdspladsen. Vejlederen er til stede på virksomheden to dage om ugen, hvilket giver mulighed for konkret coaching af deltageren $\mathrm{i}$ forhold til opgaveløsningen. Det kan eksempelvis være sparring om, hvordan man signalerer åbenhed over for kunder, eller hvordan man holder det ønskede arbejdstempo. For deltagere med psykiske udfordringer kan vejledning omhandle, hvordan man kan håndtere det på arbejdspladsen. Det kan helt konkret være hjælp til, hvor meget man kan fortælle om sine udfordringer eller øvelser i at "spille en rolle" som den glade medarbejder, selvom man i perioder har det svært. De, der har brug for at træne deres sprogkundskaber, får udleveret en glosebog, og afhængigt af behov kan der også i opfølgningen arbejdes med sproget. Andre får udleveret en notesbog til spørgsmål eller brugsanvisninger.

Selve forløbet er individuelt tilpasset, hvad angår arbejdstid, arbejdsindhold og opfølgning. Der benyttes ikke skemaer i forbindelse med opfølgningen, da det ikke vurderes at være hensigtsmæssigt i forhold til relationen med deltageren. Den tætte opfølgning foregår overvejede mundtligt med inddragelse af både deltager og virksomhed og tager udgangspunkt i to centrale spørgsmål: Hvad fungerer godt, og hvad kunne fungere bedre? Opfølgningen finder sted på forskellig vis: i korte samtaler ad hoc, ved aftalte møder med begge parter, ved separate møder med deltageren, i telefonsamtaler og mails. Opfølgningen bruges til at evaluere, kvalitetssikre og eventuelt justere deltagerens handlingsplan, træningsaktiviteter, arbejdstid og behov for supplerende tiltag. Deltagere, der har psykiske udfordringer, følges op med samtaler, der har særligt fokus på, hvad der skal til for, at de kan blive i jobbet. Forløb for denne målgruppe kombineres med ekstern behandling.

Ikea lægger vægt på kun at skulle forholde sig til én vejleder for alle deltagere i praktik. Vejlederen deltager i personalemøder og kan kontaktes på mobil uden for fast kontortid. Forudsætningen for Ikeas engagement er, at de har behov for arbejdskraft, har konkrete job at tilbyde, og at de har fokus på mangfoldighed. Mange ledige jobs slås op internt, og vejen til job er at søge et konkret job og gå til en samtale for at få det. Vejlederen understøtter ansøgningsprocessen og følger op på, hvad der gik godt eller dårligt under interviewet fra arbejdsgiverens perspektiv.

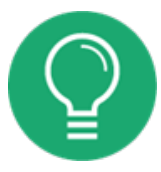

\section{Læringspunkter}

- Et tæt og forpligtende samarbejde mellem beskæftigelsesaktør, virksomhed og deltager kan fungere som rekrutteringskanal for virksomheden og sikre job for deltagere med nedsat funktionsevne.

- Vejlederen skal have mindst lige stå stor fokus på virksomheden som på den enkelte deltager. I praksis skal vejlederen kunne fungere både som sparringspartner for virksomheden og stå for en stor del af virksomhedens introduktion til de potentielt nye medarbejdere i introduktionsforløbet. 
- Når vejlederen er fast tilknyttet og integreret i en virksomhed i form af faste mødedage, eget kontor og deltagelse i personalemøder, har vejlederen bedre forudsætninger for at opretholde en fleksibel kontakt med både deltagere og samarbejdspartnere i virksomheden.

- Optræning af kompetencer og relevante skånebehov bliver lettere konkrete og relevante, når forløbet sigter mod ansættelse i virksomheden. Det styrker deltagerens motivation for at tilegne sig den nødvendige læring for at kunne begå sig i jobbet.

Forudsætninger

- Deltagere, der er motiverede for job i den pågældende virksomhed, har fysik til at klare det og kan klare sig sprogligt - eller ret hurtigt kan komme til det.

- Modellen forudsætter, at deltageren er relativt afklaret om branchevalg inden. For mange vil det betyde, at de i forvejen har gennemgået et forløb med karrierevejledning og måske snusepraktik.

- Vejledere, gerne med branchekendskab, som er i stand til at sætte sig ind i virksomheden og dens behov - og som har kompetencerne til både at arbejde med deltager og virksomhed.

- Virksomheder, der ønsker at indgå i et forpligtende samarbejde med en beskæftigelsesaktør om kontinuerligt at rekruttere og inkludere medarbejdere med nedsat funktionsevne.

- En beskæftigelsesforvaltning, der henviser til og bakker op om en så fleksibel og håndholdt indsats, som Arba Inkludering eksemplificerer - og et samarbejde med øvrige aktører om supplerende indsatser.

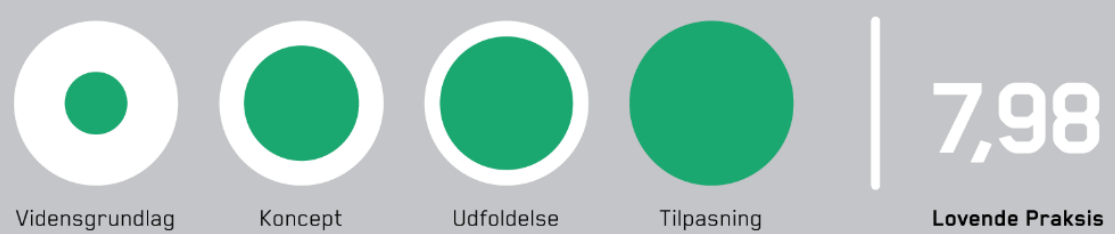




\section{Praksiseksempel 3: IPS Integration}

\section{IPS Integration}

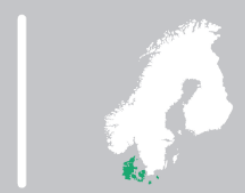

Danmark

\section{Aktører}

Human Recovery, en konsulentvirksomhed, der har specialiseret sig i IPS-metoden.

\section{Kontaktperson}

Lars Olaf Nielsen, indehaver, e-mail: lars@humanrecovery.dk, telefon: +455190 5606

Formål

At hjælpe deltagere med psykiske diagnoser og psykisk sårbarhed med at komme i job eller uddannelse og derved blive helt eller delvist selvforsørgede og opnå en væsentligt forbedret livskvalitet.

Målgruppe for indsats

Flygtninge og indvandrere, som er på integrationsydelse, kontanthjælp eller i ressourceforløb. Den overvejende barriere for at komme i job skal være psykisk.

Antal deltagere med traumer $\mathrm{i}$ indsats

Cirka 80 afsluttede forløb.

\section{Varighed af indsats}

Varierer. Den gennemsnitlige varighed for deltagere, der kommer i job, er cirka 45 uger.

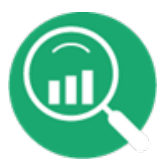

\section{Baggrund og resultater}

Human Recovery er en privat konsulentvirksomhed i Odense, der er specialiseret i Individual Placement and Support-metoden (IPS). De har udviklet indsatsen IPS Integration målrettet ledige deltagere med flygtninge- eller indvandrerbaggrund, hvor den primære barriere for at få et job handler om psykiske udfordringer, men hvor der ofte er andre barrierer i spil sideløbende. De visiterede deltagere er enten på integrationsydelse, på kontanthjælp eller i ressourceforløb og har således opholdt sig i Danmark i kortere eller længere tid.

Varigheden af et IPS-forløb er meget forskelligt. Gennemsnitligt - på tværs af alle målgrupper - varer det 44-45 uger, inden en deltager, som lykkes med at komme i job, opnår det. Succesraten i forhold til deltagere, der er motiverede og gennemfører forløbet, er at $65 \%$ er kommet i job. 
Arbejdet med kerneelementet

I IPS Integration kan der ikke udskilles et kerneelement i IPS-metoden, der er mere virksomt end de øvrige. Det centrale i praksiseksemplet er systematisk brug af hele IPSmetoden kombineret med IPS-konsulenter med samme sproglige og kulturelle baggrund som deltagerne. Deltageren kan således med det samme kan føle sig set og hørt på sit eget modersmål af en konsulent, der har et dybere kendskab til vedkommendes egen baggrund og forståelsesramme.

Alle konsulenter er uddannet i IPS-metoden og arbejder efter en IPS-manual, der er oversat til dansk. De otte IPS-principper danner ramme og baggrund for indsatsen, og i overensstemmelse med IPS-metoden laves der løbende målinger af fidelity- eller programtrofasthed - for at sikre, at indsatsen lever op til principperne i metoden (se side 26).

Et IPS-forløb er et individuelt forløb med udgangspunkt i de otte principper. De indledende møder mellem IPS-konsulent og deltager bruges til at etablere et velfungerende samarbejde, at lave udkast til en karriereprofil, som kan opdateres løbende, og lave en jobsøgningsplan. Arbejdet tager udgangspunkt i deltagerens motivation og ønsker. IPS-konsulenten yder sideløbende støtte til deltageren gennem hele processen, og den fortsætter en periode efter, at deltageren er kommet i job. I IPS Integration er omfanget af opfølgning og støtte fuldstændig individuelt, afhængigt af hvordan jobsøgningsplanen er udformet.

IPS-konsulenter behøver ikke at have en specifik uddannelsesmæssig baggrund eller dybere viden om PTSD eller andre psykiske lidelser. De skal derimod have faglige og personlige kompetencer, der gør, at de kan tilegne sig IPS-metoden og arbejde med målgruppen ud fra en recovery-orienteret tilgang. Heri ligger der en tro på, at mennesker med psykiske lidelser har kompetencer og ressourcer, der kan bruges på arbejdsmarkedet, og at arbejde på ordinære vilkår kan bidrage til, at de får det bedre. IPS-konsulenten skal kunne møde deltageren som det menneske, vedkommende er, og ikke som sin sygdom eller diagnose. Det er vigtigt at kunne arbejde ressourceorienteret, så deltageren bliver bevidst om egne kompetencer og ressourcer og bliver foreslået at udfolde dem, uagtet hvor vanskelig deltagerens situation ellers er. Dermed lægges også grundlaget for, at deltageren kan være åben og ærlig i forhold til sine udfordringer, bl.a. over for en fremtidig arbejdsplads. Samarbejdet mellem deltager og IPS-konsulent foregår uden for kontoret, hos deltageren, på virksomheden eller andre steder.

Indsatsen i IPS Integration organiseres i teams med en teamleder og et antal konsulenter. Teamlederen står for ledelse og supervision af metode og performance. Human Recovery har valgt til dels at ansætte konsulenter med samme sproglige baggrund som deltagerne, og som i nogle tilfælde selv er i gang med deres integrationsperiode. Dermed er Human Recovery en arbejdsplads præget af mangfoldighed helt ned i de enkelte 
teams. Der lægges derfor vægt på, at teamlederen har godt kendskab til danske system, lovgivning og arbejdspladskultur og kan sparre med medarbejderne om dette. Det er med til at sikre metode, mål og retning for indsatsen.

Selvom processen er baseret på deltagerens egne ønsker, kan nogle deltagere godt have modstand i starten. Det kan ske, at de har sagt ja til et forløb i jobcenteret uden egentlig at være motiverede, og der kan være andre forståelser af for eksempel kønsroller eller sygdom, der kan medvirke til at skabe modstand. Ud fra det perspektiv kan motivationen ses som en proces, der skal få lov til at udvikle sig, og det sker i samarbejdet mellem deltager og konsulent. Nogle gange skal der meget lidt til for, at motivationen udvikler sig. Et eksempel herpå er manden, der isolerede sig, og hvor man fandt ud af, at han havde spillet meget skak i hjemlandet. Han blev hjulpet til at finde en skakklub og fik hul på sin fritidsinteresse, hvorefter han blomstrede op og kom videre med sit liv. Andre gange er sagerne mere komplekse og tager længere tid. Dialogen mellem konsulenten og deltageren har betydning for, at deltageren får øjnene op for en anden synsvinkel, og det er en implicit del af forløbet at arbejde med deltagerens ejerskab til processen. Samarbejdet med virksomhederne er betinget af, at der ikke indgås praktikaftaler i forløb, hvor målet er beskæftigelse, med mindre der er udsigt til job. Spørgsmålet om, hvornår der kan komme lønkroner på, bliver italesat løbende. Praktikforløbene er så korte som muligt med mindre, de er en del af et ressourceforløb, hvor det er en del af opgaven, at sagen skal belyses og udvikles bedst muligt. Med henblik på ansættelser arbejdes der med ordinær fuldtid, ordinær deltid, fleksjob og private løntilskud. Samarbejdet med arbejdsgiveren fortsætter i en periode efter, at deltageren er kommet $\mathrm{i}$ job. Der arbejdes både med støtte til deltageren og med at klæde arbejdsgiveren på, idet målet er at få samarbejdet mellem de to parter til at lykkes.

Der foregår løbende et tværfagligt uformelt samarbejde med andre indsatser omkring deltagere, som for eksempel bostøtte, ATT (Afdeling for traume- og torturoverlevere, Psykiatrien i Region Syddanmark), misbrugsbehandlere, kriminalforsorgen eller andre. Samarbejdet foregår med udgangspunkt i en forventningsafstemning om, hvem der laver hvad - og det vigtigste, set ud fra en IPS-kontekst, er informationen om, at nu er en beskæftigelsesindsats i gang med det formål at hjælpe deltageren i job på vedkommendes egne præmisser og foranledning, men dog skabe forandring. Det kan foregå via en telefonopringning, et møde eller et trepartsmøde. Andre aktører har deres fokus andre steder, eksempelvis på at skabe ro omkring deltageren eller sygdomsbehandling. Her er det befordrende med en dialog om den præmis, at beskæftigelse nytter, og at jobrehabilitering er godt for de fleste. 


\section{Q}

\section{Læringspunkter}

- Ansættelse af IPS-konsulenter med samme sproglige og kulturelle baggrund som deltagerne styrker muligheden for at møde deltagerne der, hvor de er, og at de kan føle sig set og hørt på deres eget sprog. Samtidig skal ledelsen være indstillet på at arbejde målrettet med at implementere mangfoldighed på arbejdspladsen.

- I nogle tilfælde viser det sig, at barrieren i forhold til arbejdsmarkedet meget lille og nemt kan håndteres, eventuelt i samarbejde med arbejdsgiver, når den kommer frem i lyset. I nogle tilfælde opløser problemerne sig, når deltageren begynder at arbejde.

- Stringente og metodefaste programmer med fokus på ordinært arbejde kan skabe gode beskæftigelsesresultater for flygtninge med traumer.

- Arbejdet med IPS kræver løbende ledelsesmæssigt fokus på metode og løbende opfølgning på metodetrofasthed.

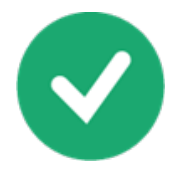

\section{Forudsætninger}

- Kommuner, der henviser deltagere til et IPS-integrationsforløb, skal være indstillet på individuelle forløb, som tager udgangspunkt i deltagerens ønsker og præferencer, og som sigter mod deltagerens ejerskab over processen og mestring af egen tilværelse.

- Tosprogede IPS-konsulenter med ingen eller lidt erfaring med det danske arbejdsmarked styrker behovet for klar og tydelig kommunikation om krav og forventninger samt tæt ledelsesmæssig opfølgning på mål, rammer og retning for at sikre fælles forståelse.

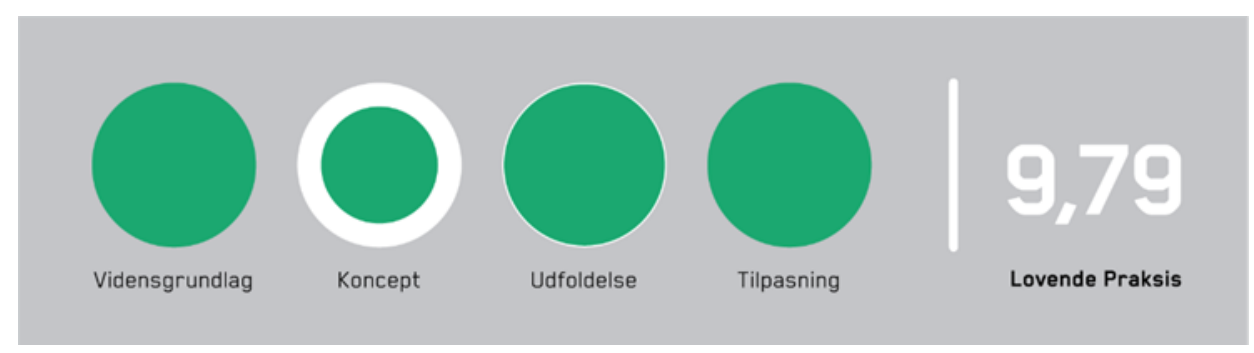




\section{Grundige afdækningsindsatser}

Kategorien Grundige afdækningsindsatser er fundet både i litteraturen såvel som i igangværende indsatser. Kategorien er defineret på baggrund af nedenstående kerneelementer:

Tabel 6: Kategorien: Grundige afdækningsindsatser

\begin{tabular}{|c|c|c|}
\hline Kerneelement & Indsatser & Litteratur \\
\hline $\begin{array}{l}\text { Grundig kortlægning af ressourcer, } \\
\text { støttebehov og interesser hos den en- } \\
\text { kelte deltager }\end{array}$ & Framsteget & Bylin, 2017 \\
\hline $\begin{array}{l}\text { Behov for individuelt tilrettelagt } \\
\text { støtte og forløb }\end{array}$ & & Bylin, 2015 \\
\hline $\begin{array}{l}\text { Helhedsorienteret afklaring gennem } \\
\text { individuelt tilrettelagte praktikforløb }\end{array}$ & Business Training & COWI, 2018 \\
\hline $\begin{array}{l}\text { Behov for tidlig opsporing af hel- } \\
\text { bredsproblemer }\end{array}$ & & $\begin{array}{l}\text { Vilhelmson, Östergren og Cuadra, } \\
2015 \text { og Norling, } 2015\end{array}$ \\
\hline $\begin{array}{l}\text { Behov for omfattende kortlægning af } \\
\text { livs- og familiesituation (i etablerings- } \\
\text { fasen) }\end{array}$ & & Eriksson Sjöö, 2014 \\
\hline
\end{tabular}

Kilde: Egen analyse af kerneelementer i indsatser og litteratur.

\subsection{Metoder i arbejdet med Grundige afdækningsindsatser}

Metoderne i arbejdet med afdækning er primært konkrete afdækningsredskaber, det vil sige forskellige systematikker og spørgeskemaer. Metoderne anvendes hovedsageligt med det formål at afdække ressourcer og motivation hos den enkelte.

Både i praksiseksemplerne og litteraturen er der flere forslag til konkrete redskaber til afdækning af ressourcer og udfordringer i forhold til arbejdsmarkedet. De nævnte redskaber er ikke udviklet specifikt til flygtninge og indvandrere, men til bredere målgrupper. For henvisning til konkrete redskaber og materialer, se Boks 4.

Formålet med at anvende metoderne er - som det også ses i praksiseksemplerne at designe den rigtige plan for deltagerne og finde deres motivation og ressourcer.

Et væsentligt fundament for afdækningsindsatser er den gode relation og tillid mellem deltagere og medarbejdere. Relation og tillid er især nævnt i de konkrete praksiseksempler, hvor der bliver arbejdet med relationsopbygning via samtaler. Teknikker $\mathrm{i}$ den proces er ressourceorienterede og anerkendende samtaleteknikker. 


\section{Boks 4: Konkrete redskaber til afdækning}

Redskaber til afdækning nævnt i litteratur eller brugt i praksiseksempler

- $\quad$ SASSAM - Strukturerad Arbetsmetodik för Sjukfalls utredningar och samordnad rehabilitering, der er udviklet til udredning af sygedagpengemodtagere. SASSAM nævnes i en rapport som et muligt redskab til målgruppen (Forsäkringskassan och Arbetsförmedlingen, 2016).

Link til SASSAM-kort: https://www.forsakringskassan.se/wps/wcm/connect/713c62ag-e2c2461b-a81a-63340d6368d2/SASSAM_karta.pdf?MOD=AJPERES

Link til SASSAM-metodehæfte:

https://www.forsakringskassan.se/wps/wcm/connect/354c5618-023d-45c1-8aac-

eaf6gbob40ao/sassam_metodhafte_2011_08.pdf?MOD=AJPERES

- FIA - Förutsättningar Inför Arbete, der er et redskab til afdækning af arbejdsløse med uklare udfordringer, der har været på overførselsindkomst omkring 5 måneder eller mere. FIA anvendes i Hela Familjen 2.0, der beskrives på side 58.

Link til FIA-interviewguide:

http://www.socialstyrelsen.se/SiteCollectionDocuments/2017-7-1-FIA-intervju-omraden.pdf Link til FIA-manual:

http://www.socialstyrelsen.se/Lists/Artikelkatalog/Attachments/20647/2017-7-1.pdf

- DOA - Dialog om arbetsförmåga, der er spørgeskema baseret på deltagerens selvevaluering, observationer og dialog. Fremstegat anvender DOA i deres praksis (se side 44).

DOA findes også på engelsk og kan købes fra denne hjemmeside:

https://www.arbetsterapeuterna.se/Om-forbundet/Forbundets-forlag/Dialog-om-arbetsformaga-DOA/

\subsection{Vidensgrundlag i litteraturstudiet for Grundige afdækningsindsatser}

Der er to studier af specifikke interventioner, der dokumenterer virkningen af at arbejde med Grundige afdækningsindsatser. Derudover er der fire referencer i litteraturstudiet, der underbygger relevansen af at arbejde med Grundige afdækningsindsatser.

De to studier af specifikke interventioner er henholdsvis en slutevaluering og en midtvejsevaluering af de to praksiseksempler, der præsenteres i afsnit 5.3. Slutevalueringen af projekt Framsteget viser, at 7 ud af 25 deltagere er kommet i arbejde eller uddannelse efter projektets indsats, der består af grundig afdækning og individuelt tilpasset støtte (Bylin, 2017). Midtvejsevalueringen af projekt Business Training er primært kvalitativ og blandt andet baseret på interview med målgruppen. Evalueringen viser, at målgruppen har behov for personligt tilpassede forløb, og at de igennem projektets helhedsorienterede afdækning oplever forøget selvtillid i forhold til arbejdsmarkedet (COWI, 2018). 
En hovedanbefaling i forstudiet til projekt Framsteget er, at målgruppen har behov for meget individuelt tilpassede forløb for at kunne blive selvforsørgende. Forstudiet har afdækket målgruppen og dens behov gennem kvalitative interviews med fagpersoner og kortlægning af projektindsatser (Bylin, 2015).

To kortlægninger af virkningsfulde indsatser anbefaler en grundig afdækning tidligt $\mathrm{i}$ integrationsprocessen. Den tidlige afdækning er hovedsageligt fokuseret på opsporing af flygtninges helbredsproblemer. Begge rapporter vurderer, at en tidlig identifikation og indsats i forhold til dårlig psykisk helse bidrager til progression for den enkelte - både i forhold til helbred og arbejdsmarked (Vilhelmsson, A., Östergren PO., Bjørngren Cuandra, Carin, 2015 og Norling, 2015).

På baggrund af kvalitative interviews med fagpersoner og målgruppen beskriver Eriksson Sjöö, at en detaljeret og helhedsorienteret kortlægning af den enkeltes livssituation vil bidrage til en bedre integrationsproces og bedre arbejdsmarkedsrettede indsatser. Indsatserne vil efter kortlægningen bedre kunne tage højde for den enkeltes livssituation og behov (Eriksson Sjöo, 2014).

\subsection{Eksempler på Grundige afdækningsindsatser}

To af undersøgelsens praksiseksempler tilhører denne kategori: Den svenske indsats "Framsteget" og den danske indsats "Business Training".

"Framsteget" er det eneste praksiseksempel i undersøgelsen, der er afsluttet. Projektet indgår, da virksomheden Inda.nu fortsat laver lignende indsatser, og projektleder og medarbejdere fra projektet derfor kunne besøges.

Beskæftigelsesresultaterne ligger på $28 \%$ for begge indsatser. Målingerne af effekter er baseret på en evalueringsrapport for "Framsteget" og "Business Trainings" egne opgørelser.

Praksiseksempler er begge af relativt kortere varighed og for en målgruppe med relativt komplekse udfordringer. Begge aktører har påpeget i interviewene, at en udvidelse af projekternes varighed ville kunne påvirke resultaterne positivt.

Begge indsatser arbejder med metoder til afdækning, som bygger på tillid mellem deltagere og fagpersoner. Afdækning sker i begge indsatser i virksomhederne, og afdækningsprocessen ses som en vej til at anskueliggøre ressourcerne hos deltagere ikke mindst for dem selv. 


\section{Praksiseksempel 4: Framsteget}

\section{Framsteget}

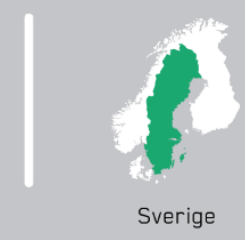

Aktører

Inda.nu

\section{Kontaktperson}

Anna Bylin, projektledare/kvalitet- och metodansvarig, e-mail: anna.bylin@inda.nu, telefon: +46707884440 , www.inda.nu

Formål

Deltagerne kommer i ordinært arbejde eller uddannelse.

Målgruppe for indsats

Mennesker med anden etnisk baggrund end svensk med funktionsnedsættelse eller PTSD, alternativt mistanke om funktionsnedsættelse/PTSD.

Antal deltagere med traumer $\mathrm{i}$ indsats

14 (ud af i alt 25).

Varighed af indsats

1 år- 2016.

\section{Baggrund og resultater}

Framsteget var et et-årigt projekt, der blev afsluttet i 2016 i Sverige. Projektet var baseret på Supported Employment, men med en ekstra stor vægt på kortlægningen af deltagernes ressourcer og støttebehov. Projektet bestod af individuelle samtaler med henblik på kortlægning af deltagernes ressourcer, gruppeaktiviteter og praktik og/eller arbejde. Der var derudover tilknyttet en psykolog til projektet, som deltagere med traumeproblemstillinger med behov for støtte via samtaler kunne henvises til.

Projektet var rettet mod ledige med anden etnisk baggrund end svensk, der havde afsluttet det to-årige etableringsprogram, og som havde en funktionsnedsættelse og/eller PTSD, eller hvor der var mistanke om funktionsnedsættelse eller PTSD.

Projektet blev udført af den private aktør Inda.nu i et samarbejde med Askersund, Laxå, Hallsberg og Kumla kommuner, Försäkringskassan og Arbetsförmedlingen, Region 
Örebro Län. Projektet var finansieret af FINSAM Sydnärke (Finansiel samordning af rehabiliteringsindsatser mellem arbejdsformidling, forsikringskassen, kommune og landsting/region).

Før Framsteget blev sat i gang, gennemførte inda.nu et forstudie kaldet "första steget", der kortlagde målgruppens størrelse i området og deres behov for en tilpasset arbejdsmarkedsindsats (Bylin, 2015).

Formålet med projektet var, at deltagerne skulle bevæge sig tættere på egen forsørgelse. Der deltog 25 mennesker i projektet, og heraf var 7 i arbejde og uddannelse, efter indsatsen var slut.

Der er desuden blevet lavet en analyse af de samfundsøkonomiske gevinster ved at gennemføre Framsteget. Analysen viser, at Framsteget forventes at tjene sig selv ind efter 22 måneder og efter 5 år kan forventes at give en samfundsøkonomisk gevinst på 4,5 millioner kroner. Beregningen er baseret på data om de 25 deltagere i projektet og forudsætter, at de bibeholder den status, som de havde efter projektets afslutning (Huldt, 2017).

\section{Arbejdet med kerneelementet}

Kerneelementet i Framsteget er grundig kortlægning af ressourcer, støttebehov og interesser hos den enkelte deltager.

Framsteget brugte en konkret metode inden for Supported Employment kaldet SATSA, der er udviklet til mennesker med asperger. SATSA står for Samverkan, Asperger, Till, Sysselsättning, Arbete. SATSA har tre skridt:

- Kortlægning af styrker, støttebehov og interesseområder hos deltageren.

- Kontakt til relevante arbejdspladser.

- Praktik/arbejde med kontinuerlig opfølgning med deltager og arbejdsgiver.

SATSA-metoden har en grundigere og mere omfattende kortlægningsfase end Supported Employment har traditionelt. Kortlægningsfasen varede mellem 3 og 6 måneder og gennemførtes primært via ugentlige individuelle samtaler med jobkonsulenter ansat i projektet. Kortlægningen omhandlede deltagernes arbejdsbaggrund, uddannelse, ressourcer, ønsker, sundhedsstatus og støttebehov.

For at få udbytte af de individuelle samtaler var det nødvendigt at bruge tid og energi på at opbygge en tryg relation mellem deltager og jobkonsulent. Det brugte konsulenterne typisk de første samtaler til.

De individuelle samtaler byggede på en anerkendende tilgang og et salutogent perspektiv, hvor fokus er på deltagernes styrker og de faktorer, der bidrager til deltagerens 
sunde liv, oplevelse af meningsfuldhed og sammenhæng i livet. Konkret fik det den betydning, at jobkonsulenterne i samtalerne spurgte ind til værdier, ressourcer og drømme. Metoden gav indblik i deltagernes styrker og kompetencer og bidrog til et fokusskift hos deltagerne, hvor de langsomt fik øget fokus på de ting, der fungerede i deres liv, og de kompetencer, de kunne bruge på arbejdsmarkedet. I den sammenhæng havde det også betydning, at der var en psykolog knyttet til projektet, som deltagere med traumerelaterede udfordringer kunne bruge. Psykologen kunne arbejde med traumerelaterede symptomer og mestring sideløbende med den mere arbejdsmarkedsrettede indsats.

Som en støtte i jobkonsulenternes kortlægning benyttedes samtaleskemaer, særligt selvvurderingsmaterialet DOA (Dialog Om Arbejdsevne). Materialet består af en række spørgsmål, der stilles til deltageren selv inden for områder som roller og vaner, fysisk formåen og samarbejds- og kommunikationsevner. Ved de enkelte spørgsmål skulle deltageren vurdere sig selv på en skala fra 1 til 5 . Det kunne være udfordrende for deltagerne at svare på spørgsmålene og forstå formen, fordi de ikke tidligere havde udfyldt selvevalueringer. Det til trods fungerede DOA som et relevant afsæt for samtaler om arbejdsmarkedsrettede kompetencer. Desuden kunne jobkonsulenten bruge redskabet til at støtte deltageren i at få øje på egne ressourcer. Redskabet viste sig både at være relevant i forhold til at afdække ressourcer og have dialog om eventuelle begrænsninger.

For deltagere, der ikke havde arbejdsmarkedserfaring, uddannelse eller havde begrænsede sprogkundskaber, var skemaet mindre brugbart, da en del spørgsmål kræver forhåndskendskab til arbejdsmarkedet. Afdækningen skete derfor også via observation ved holdbaserede aktiviteter og individuelle samtaler samt via vurderinger sideløbende med praktik.

Erfaringen fra Framsteget er, at der er behov for at bruge særligt meget tid og energi på kortlægningen, både for at få deltagerne til at få øje på deres egne ressourcer, og for at få nok viden om deltagerne til at lave korrekte match med virksomheder.

Mange af deltagerne havde ikke tidligere tænkt over deres ressourcer på denne måde. Kortlægningen gav dermed deltagerne en ny selvindsigt og selvtillid i forhold til, hvilke af deres kompetencer og ressourcer der kunne bruges på arbejdsmarkedet.

Jobkonsulenterne oplevede, at en grundigere og mere systematisk kortlægning gjorde det lettere at finde relevante virksomheder og forberede dem, så det endte med mere vellykkede match.

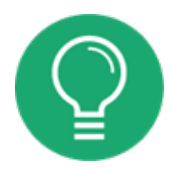

\section{Læringspunkter}

- Ressourcefokus samt tid brugt på grundig afdækning af ressourcer kan styrke deltageres selvtillid og tro på en fremtid på arbejdsmarkedet.

- Skemaer til støtte for afdækningen kan give afsæt for relevant dialog om arbejdsmarkedsrettede kompetencer. 
- For deltagere uden arbejdsmarkedserfaring og med få sprogkundskaber sker afdækning bedst gennem observation under aktiviteter.

- Vellykkede virksomhedsmatch kræver deltagere, der er grundigt afdækkede og har indsigt i egne ressourcer og begrænsninger.

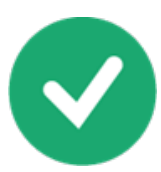

\section{Forudsætninger}

- Konsulenter der er uddannet $\mathrm{i}$ anerkendende samtaleteknik og $\mathrm{i}$ at anvende DOA eller tilsvarende skemaer til afdækning.

- Ressourcer og tid til at arbejde med at opbygge tillid og sætte fokus på det, der virker.

- Adgang til psykologbistand ved behov.

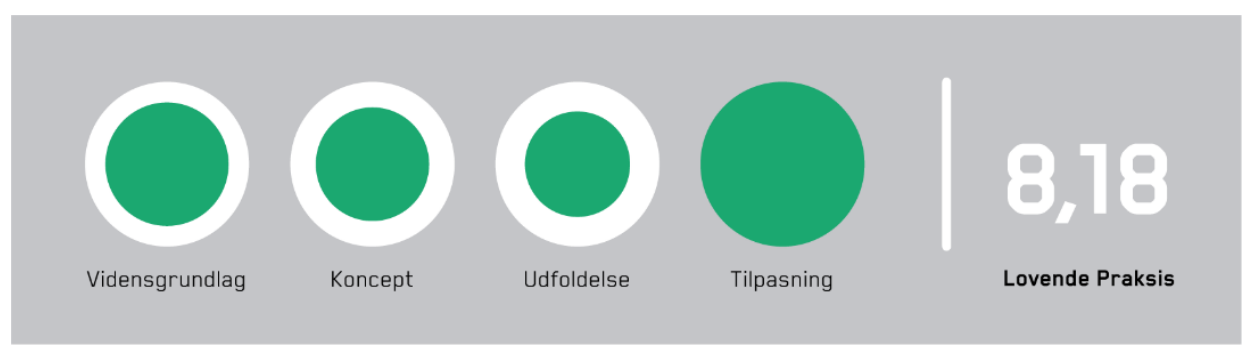




\section{Praksiseksempel 5: Business Training}
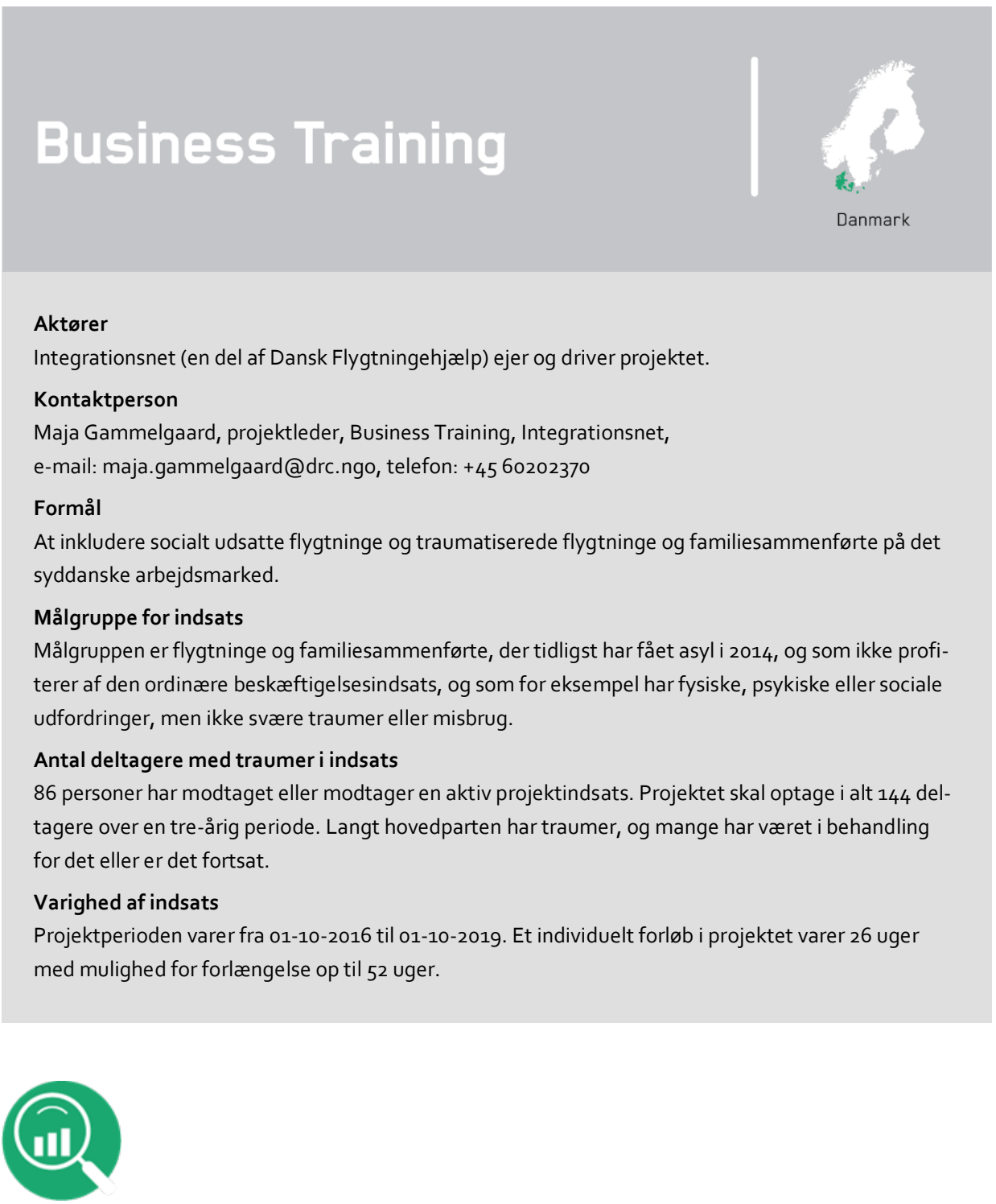

\section{Baggrund og resultater}

Business Training er bevilget midler fra den Europæiske socialfond under Vækstforum Syddanmark. Projektet har til formål at inkludere udsatte nyankomne flygtninge og familiesammenførte på det regionale arbejdsmarked. Baggrunden er dels, at der er mangel på arbejdskraft i området, og dels et ønske om at udbrede et mere ressourceorienteret syn på udsatte flygtninge. Afsættet for projektet er at udvikle den skjulte arbejdskraftreserve, der er i denne målgruppe. Projektet skal give mulighed for at afklare og udvikle målgruppens kompetencer i forhold til en fremtid på arbejdsmarkedet. 
Et Business Training-forløb er individuelt tilrettelagt og består af screening, undervisning, individuelle samtaler, "place-and-train"-forløb i en lokal virksomhed, supportservice til virksomheden og mentorforløb, hvis deltageren ønsker det. For at blive optaget i projektet skal deltageren vurderes til at have potentiale for på kort eller langt sigt at kunne indgå på arbejdsmarkedet og kunne deltage i projektet minimum 15 timer om ugen. Henvisning til projektet sker via sagsbehandlere i de deltagende kommuner.

Projektets partnerskab består af Kolding Kommune, Business Kolding og Integrationsnet. Ud over Kolding Kommune er projektet udbredt til Odense, Haderslev og Vejen kommuner. Projektledelsen ligger hos Integrationsnet, der er en konsulentvirksomhed under Dansk Flygtningehjælp.

De forventede effekter af Business Training er blandt andet, at $100 \mathrm{ud}$ af 144 visiterede har gennemført et forløb, at 12 er kommet i ordinær beskæftigelse eller blevet selvstændige, at 23 er kommet i støttet beskæftigelse, og at 30 kommer i gang med at søge job umiddelbart efter afslutningen. Status cirka to tredjedele inde i forløbet er, at 46 ud af 86 deltagere har afsluttet et forløb i Business Training. Heraf har syv fået ordinært job, én har startet selvstændig virksomhed og én har påbegyndt en SU-berettiget uddannelse. Endvidere er fire kommet i job med løntilskud, og seks er i gang med at søge job efter at have afsluttet projektet. Nogle deltagere er gået ud af projektet på grund af andre udfordringer end ledighed. På baggrund af de dokumenterede resultater i midtvejsevalueringen har Business Training opnået en ekstra bevilling på godt et år, der blandt andet betyder en forlængelse frem til 31-12-2020 og 100 ekstra pladser samt tilbud om efterværn.

\section{Arbejdet med kerneelementet}

Kerneelementet i Business Training er helhedsorienteret afklaring gennem individuelt tilrettelagte praktikforløb. Det foregår via hurtig udplacering i praktik kombineret med en afdækkende indsats omkring målgruppens sociale og psykiske udfordringer. Indsatsen er rettet mod inklusion på arbejdsmarkedet, og resultatet kan bestå i ordinært arbejde, støttet beskæftigelse eller praktik.

I projektet er der ansat konsulenter med forskellige faglige kompetencer til at dække undervisning og faglig kvalificeret opfølgning i forhold til sociale, psykiske, helbredsmæssige og beskæftigelsesorienterede udfordringer. For eksempel er der ansat en sygeplejerske til at støtte op om deltagere, der har behov for at håndtere konkrete helbredsmæssige udfordringer for at klare et arbejde.

Business Training har udviklet et detaljeret screeningsværktøj til afdækning af målgruppen. Det indeholder blandt andet oplysninger om uddannelse, tidligere beskæftigelse, helbred, motivation samt vurdering fra sagsbehandler i forbindelse med henvisningen til 
projektet. Herefter indkalder Business Training deltageren til et interview med udgangspunkt i det udfyldte værktøj. På baggrund heraf lægges der en individuel plan for den enkeltes forløb, afhængigt af den enkeltes kompetencer, behov og muligheder.

En væsentlig del af målgruppen har vist sig at være temmelig uafklaret, hvad angår kvalifikationer, kompetencer og helbred. I flere tilfælde har de kommunale sagsbehandlere og deltagere primært haft fokus på helbredsmæssige barrierer og i mindre grad på afdækning af uddannelsesmæssige kvalifikationer og faglige kompetencer. Kun halvdelen har været i praktik, før de optages i projektet.

Deltagernes udfordringer er nogle gange større eller mere komplekse end forventet. De kan for eksempel handle om sygdom eller problemer med børnene, hvilket i sidste ende kan gøre det nødvendigt at sende vedkommende tilbage til kommunen, indtil udfordringerne er løst. Det hænder også, at en deltager er blevet fejlbedømt som ikke-motiveret, selvom barrieren måske ligger et helt andet sted og nemt kan tages hånd om.

Arbejdet med at finde den rette praktik tager udgangspunkt i deltagerens egne ønsker og muligheder, og der etableres først en praktik, når der er fundet et relevant match mellem deltager og virksomhed. Deltageren opfordres fra starten til at være sin egen jobkonsulent og får fra projektet hjælp til at få defineret en række delopgaver på vejen mod målet. På den måde får deltagerne fra starten et medansvar og bliver ledt igennem en proces, hvor de oplever, at de selv kan ændre deres egen situation. Samarbejdet med deltageren finder i høj grad sted via individuelle samtaler og fortsætter forløbet igennem. Den empowerment-orienterede metode i Business Training, og muligheden for at få anerkendt sine kompetencer i en virksomhed, har for nogle betydet, at de har fået motivationen og troen på, at de kan få et arbejde, tilbage.

Den sideløbende undervisning har blandt andet til formål at give deltagerne viden og forståelse for normer og adfærd på en dansk arbejdsplads. Efter behov kan den enkelte deltager få tilknyttet en mentor. Kriteriet for en mentoropgave er, at der er sten på vejen, der skal flyttes, og en mentoropgave kan have forskelligt formål alt efter, hvilken type udfordring den retter sig imod.

Den individuelle opfølgning, mens deltageren er i praktik, kan både handle om, hvordan det går i praktikken, og forhold i andre dele af deltagerens liv, der har betydning for vedkommendes mulighed for at fokusere på at komme i arbejde. Det kan også handle om hjælp til ret konkrete ting som for eksempel lægebesøg og samtaler på jobcenteret eller udfordringer i forbindelse med børns sygdom.

Samarbejdet med virksomhederne er baseret på en kontinuerlig kontakt med den samme kontaktperson. Projektet følger tæt op - som regel på ugentlig basis - men det varierer efter aftale og behov. Opfølgningen handler om, hvordan det går, og om noget skal ændres, eksempelvis i forbindelse med arbejdsopgaver eller timetal. På trepartsmøder med deltager og virksomhed udfyldes der progressionsskemaer på baggrund af virksomhedens tilkendegivelser af, hvordan deltageren klarer sig i praktikken. Projektet tilbyder endvidere en 24/7 supportservice til virksomhederne, som betyder, at de altid kan ringe, hvis de har behov for støtte. Denne service vurderes som værende en afgørende forudsætning for, at virksomhederne involverer sig i forløbet. 
Ifølge midtvejsevalueringen oplever deltagerne især teamsessions, praktikforløb og relationen til projektets medarbejdere som værdifulde. Deltagerne får mere selvtillid, når de får klarlagt egne kompetencer og oplever, at de kan bruge og udvikle deres kompetencer på en arbejdsplads. Et opmærksomhedspunkt er, at det kan være uhensigtsmæssigt med tidsafgrænsede forløb i så komplekse sager, ligesom der er en risiko for, at deltagerens tilknytning til arbejdsmarkedet er for sårbar, hvis ikke der etableres et efterværn.

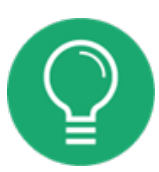

Læringspunkter

- Hvis der ikke fra kommunens side er foretaget en systematisk dokumentation af målgruppen, deres kompetencer og udfordringer, bliver det op til projektet at sørge for det, hvis der skal skabes resultater. Dette skal ses i sammenhæng med en målgruppe, hvoraf de fleste er traumatiserede og har komplekse udfordringer.

- Et sideløbende fokus på sociale, psykiske og helbredsmæssige udfordringer bidrager til en helhedsorienteret afklaring, som er et godt grundlag for at tilrettelægge en skræddersyet støtte på vejen mod job med involvering af de relevante faglige kompetencer.

- Trepartssamtaler mellem virksomhed, deltager og projektets kontaktperson er hensigtsmæssige, blandt andet fordi deltageren tillægger virksomhedens udtalelser større autoritet, når det handler om muligheden for at få et job.

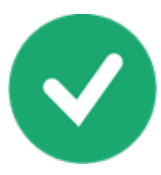

Forudsætninger

- Kvalitetssikring af kommunernes afdækning af deltagerne i forbindelse med visitation til indsatsen.

- En bred vifte af medarbejderkompetencer, så den tværfaglige indsats bygger på faglig indsigt i forhold til integration, beskæftigelse, sundhed, sociale forhold samt viden om og erfaring med flygtninge med traumer.

- Et helhedsorienteret syn på målgruppens ressourcer og udfordringer samt en ressourceorienteret indfaldsvinkel til den kompetenceafklarings- og udviklingsproces, der er forudsætningen for, at så mange som muligt kommer $\mathrm{i}$ job - eller inkluderes på arbejdsmarkedet på andre vilkår. 
- Tæt opfølgning og dialog med både deltagere og virksomheder, herunder fælles opfølgning på deltagerens progression, og hvad der skal til for at opnå ansættelse.

- Adgang til relevante redskaber til screening.

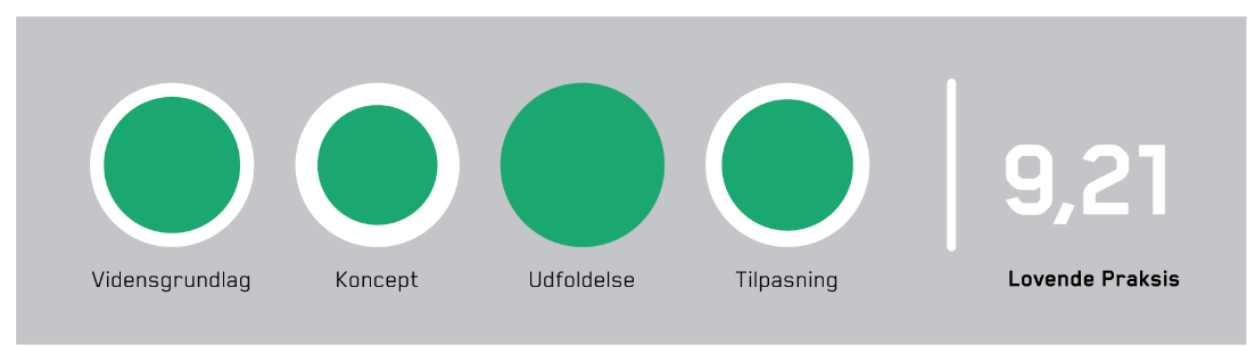




\section{Helhedsorienterede og tværfaglige indsatser}

Kategorien Helhedsorienterede og tværfaglige indsatser er både fundet $\mathrm{i}$ igangværende indsatser og i særdeleshed også i litteraturstudiet. Kategorien er defineret på baggrund af kerneelementer fra nedenstående indsatser og tekster:

\begin{tabular}{lll}
$\begin{array}{l}\text { Tabel 7: Kategorien: Helhedsorienterede og tværfaglige indsatser } \\
\text { Kerneelement }\end{array}$ & Indsatser & Litteratur \\
\hline $\begin{array}{l}\text { Koordination og helhedssyn } \\
\begin{array}{l}\text { Helhedssyn og tværfagligt } \\
\text { samarbejde om deltagernes individu- } \\
\text { elle planer }\end{array}\end{array}$ & Hela Familjen 2.0 & Finsam, 2014, Gullers Group, 2015, \\
$\begin{array}{l}\text { Tværfaglighed kan øge kvalitet og } \\
\text { effekt }\end{array}$ & $\begin{array}{l}\text { Jansson og Wiren, 2016, Widerberg, } \\
\text { 2017 }\end{array}$ \\
$\begin{array}{l}\text { Tværfaglige indsatser bør bygge på } \\
\text { eksisterende strukturer }\end{array}$ & Boll, Damgaard og Høeberg, 2014 \\
$\begin{array}{l}\text { Øget behov for samarbejde mellem } \\
\text { sundheds- og arbejdsmarkedsaktører }\end{array}$ & Norling, 2015 \\
$\begin{array}{l}\text { Ønske om øget tværfagligt } \\
\text { samarbejde }\end{array}$ & Försäkringskassan och Arbetsförmed- \\
$\begin{array}{l}\text { Behov for at tænke arbejde bredere } \\
\text { som meningsfulde aktiviteter og } \\
\text { involvere civilsamfundet }\end{array}$ & lingen, 2016 \\
\hline
\end{tabular}

Kilde: Egen analyse af kerneelementer i indsatser og litteratur.

\subsection{Metoder i Helhedsorienterede og tværfaglige indsatser}

I denne kategori er der metoder, der omhandler organisering og koordination af samarbejde mellem forskellige forvaltninger og/eller faggrupper, herunder særligt sundheds- og arbejdsmarkedsaktører, og der er metoder, der primært handler om tilgangen og synet på den enkelte deltager $\mathrm{i}$ indsatsen.

Metoderne til organisering og koordination omhandler eksempelvis tilrettelæggelsen af samarbejdet, hvilke faggrupper, der skal være med, og hvordan man opnår respekt for hinandens faglighed.

Her kan det være virkningsfuldt at etablere samarbejder og indsatser, der bygger på eksisterende strukturer fremfor projektorganiseringer. Permanente strukturer øger forudsætninger for at fokusere på den enkelte og få mere smidige samarbejdsprocesser (Norling, 2015). Der skal afsættes tid til at få gensidig forståelse og kommunikation på 
plads, når man skal arbejde tværfagligt, og der skal være tydelige fælles mål for arbej$\operatorname{det}$ (Boll et al., 2014).

De metoder, der omhandler tilgangen til den enkelte, har fokus på helheden. I praksis betyder det, at selvom arbejde er målet for indsatserne i kategorien, er midlerne også at sætte ind i forhold til andre livsområder, eksempelvis i forhold til helbred og socialt netværk. Metoderne søger at tage højde for kompleksiteten i den enkeltes livssituation og arbejde med de faktorer, der har ledt til eller fastholder den enkelte i arbejdsløshed og i en dårlig helbredstilstand. Helheden kan som eksempel være familie, som i praksiseksemplet "Hela Familjen 2.0", hvor der er fokus på, hvordan eksempelvis børn eller partneres trivsel har betydning for den enkeltes beskæftigelsessituation.

\section{Boks 5}

Nye indsatser kan med fordel bygge på eksisterende strukturer

Tænk forankring ind i projekterne fra start af

Norling anbefaler, på baggrund af en analyse af forskellige succesrige indsatser, at nye indsatser bygger på eksisterende strukturer. Permanente strukturer sikrer forudsætninger for at fokusere energi på at udvikle samarbejdet frem for at bygge og genopbygge midlertidige samarbejdsstrukturer.

I tråd med den anbefaling arbejder "Hela Familjen 2.0" med en forbedret indsats inden for de eksisterende strukturer i organisationen. De ændrer på ressourcetilførslen - og tid og kræfter til arbejdet men ikke det grundlæggende organisatoriske set-up. Det kan ses som en måde at lave projektindsatser, der er mere bæredygtige på.

Kilde: Norling, 2015

\subsection{Vidensgrundlaget i litteraturstudiet for Helhedsorienterede og tværfaglige indsatser}

Der er fire evalueringer af samme intervention, der dokumenterer virkningen af at arbejde helhedsorienteret og tværfagligt. Der er derudover fem referencer i litteraturstudiet, der underbygger relevansen af at arbejde helhedsorienteret og tværfagligt. Referencerne behandler både nyankomne flygtninge såvel som flygtninge, der har været langvarigt ledige. Målgruppen i publikationerne har alle sammensatte udfordringer af beskæftigelsesmæssig, helbredsmæssig og social karakter.

Den specifikke intervention, der er evalueret, er et projekt i Malmö kaldet PTSDCentret. PTSD-Centrets indsatser er videreført i Avanti, der beskrives som praksiseksempel i afsnit 6.3. Der er tre evalueringer af PTSD-Centret, hvori der indgår kvantitative resultatmålinger. De tre rapporter beskriver, at mellem 35-70 \% af deltagerne i indsatsen er afsluttet til arbejde eller studie efter projektets indsats, der beskrives som helhedsorienteret og tværfaglig (Finsam, 2014, Jansson og Wiren, 2016 og Widerberg, 2017). Den sidste evaluering er kvalitativ og konkluderer blandt andet, hvordan tværfagligt samarbejde bidrager positivt til individernes rehabilitering og projektets resultater (Gullers Group, 2015). 
I en undersøgelse af indsatsen for traumatiserede i Danmark, konkluderes det, at traumatiserede flygtninge har behov for koordination af deres forløb, da det kan være vanskeligt for målgruppen at overskue komplekse forløb med mange samarbejdsflader. Rapporten beskriver, hvordan størstedelen af de adspurgte kommunale medarbejdere i Danmark er venige i, at indsatsen for traumatiserede flygtninge er koordineret og helhedsorienteret, og i at den bygger på et tværfagligt samarbejde (LG Insight, 2013).

Flere af rapporterne underbygger særligt behovet for et velfungerende samarbejde mellem beskæftigelsesindsats og sundhedsaktører (LG Insight, 2013, Försäkringskassan og Arbetsförmedlingen, 2016 og Boll et al., 2014). I evalueringen af "Brug for alle" vurderes det, at deltagelsen af sundhedsfagligt personale i et tværfaglig team har bidraget til, at deltagere med psykiatriske lidelser har følt sig taget alvorligt (Boll et al., 2014).

På baggrund af en kortlægning af virkningsfulde indsatser beskriver Norling, hvordan et fokus på at styrke den enkeltes helbred tidligt i forløbet kan medvirke til resultater på andre livsområder ved eksempelvis at påvirke indlæringsevne og sociale kompetencer positivt (Norling, 2015).

En svensk rapport, der afdækker eksisterende værktøjer og metoder til at fremme nyankomnes indtræden på arbejdsmarkedet, peger på, at en del af forklaringen på, at målgruppen ikke får en relevant koordineret indsats er, at helbredsproblemer hos målgruppen ikke bliver identificeret på grund af strukturelle barrierer (Försäkringskassan og Arbetsförmedlingen, 2016).

For nogle målgrupper af flygtninge kan det give mening at tænke arbejde bredere og overveje muligheder for i højere grad at inddrage civilsamfund og foreningsliv. Argumentet er, at deltagelse i sociale sammenhænge drevet af interesser kan være vejen til beskæftigelse og entreprenørskab. Analysen er baseret på et projekt om flygtninges helbred i etableringsprocessen (Vilhelmsson, Östergren og Cuandra, 2015). 


\section{Boks 6}

\section{Arbejde med ligestilling i integrationsindsatsen}

Får flygtningekvinder og -mænd samme indsats?

Tal på beskæftigelsesområdet viser, at det går bedre for mænd med flygtningebaggrund end for kvinder (Simic (red.), 2018). Det skyldes til dels kvindernes manglende erhvervserfaring, men flere undersøgelser peger på, at det også skyldes, at den indsats, der tilbydes mændene, er mere beskæftigelsesrettet (ibid. og Styrelsen for International Rekruttering og Integration, 2018).

I Sverige er der et stort projekt i gang med afprøvning af ligestillingstiltag for kvinder med anden etnisk baggrund end svensk. Projektet vil blandt andet teste, hvad det betyder for kvindernes beskæftigelse, at kvinderne får en indsats, der kvalitativt er den samme som for mændene. Projektet løber fra 2018 frem til 2021 og afprøver blandt andet også Supported Employment for kvinderne. Læs om projektet her: https://www.esf.se/sv/Resultat/Projektbanken-2014-2020/Alla-Projekt/Jamstalld-etablering/

At arbejde med kønsligestilling kræverikke nødvendigvis en omlægning af selve indsatsen, men mere en konstant opmærksomhed i alle indsatser på at sikre ligebehandling og på at modvirke stereotype forestillinger om køn. I en rapport om den svenske arbejdsformidlings indsats anbefales det blandt andet aktivt at måle og sørge for, at kvinder får de samme møder, støtte og indsatser som mænd. Denne anbefaling gælder også for kvinder og mænd, der modtager en mere traumespecifik indsats (Cheung, 2018, 5. 33).

I Hela Familjen 2.o bruger de en enkel tjekliste til at sikre opmærksomhed på ligestilling. Listen støtter medarbejderne $i$ at huske at give samme informationer og tilbud til både mænd og kvinder. Tjeklisten findes eksempelvis som klistermærke, der kan sættes, så man som sagsbehandler ser det, når man afholder samtaler:

\section{Figur 2: Tjekliste - Ligestilling}

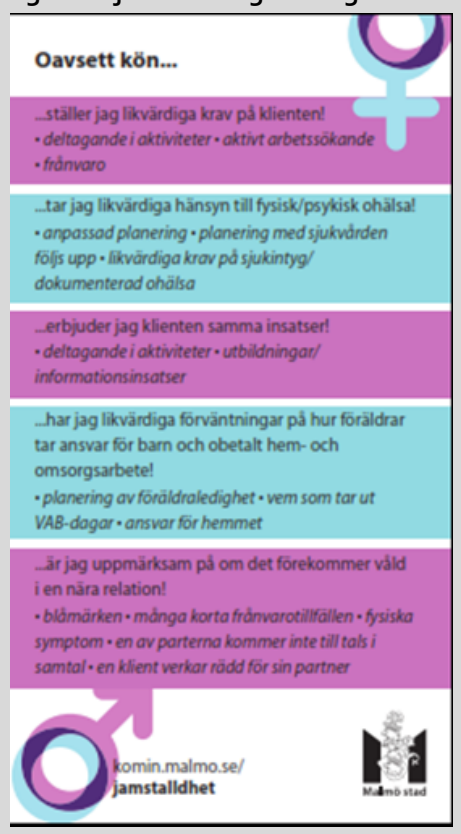

Kilde: Gengivet med tilladelse fra Hela Familjen 2,0 


\subsection{Eksempler på Helhedsorienterede og tværfaglige indsatser}

Der er udvalgt to svenske praksiseksempler i denne kategori, der begge bliver udført i Malmö. Indsatsen "Hela Familjen 2.0" er en helhedsorienteret indsats. Indsatsen er ikke kun for flygtninge med traumesymptomer, men for familier der har været i længere tid på overførselsindkomst. "Avanti" er en tværfaglig indsats rettet specifikt mod flygtninge med traumer og/eller eksilstress.

Beskæftigelsesresultaterne er mellem 24 og $38 \%$. Målingerne af effekter er baseret på indsatsernes egne opgørelser.

Begge praksiseksempler er baseret på tidligere projekter. "Avanti" viderefører en tidligere indsats, der hed "PTSD-Center", og før det "Exigo" og "Introrehab". "Hela Familjen 2.0" bygger på projektet "Hela Familjen". Alle de tidligere indsatser er blevet evalueret, og det er vurderet relevant at videreføre indsatserne i en tilpasset form. Det er besluttet, at "Hela Familjen 2.0" skal videreføres i normal drift i Malmö på baggrund af gode resultater af indsatsen.

Målgrupperne i disse to indsatser har relativt komplekse udfordringer. I de to praksiseksempler er der inspiration til, hvordan man arbejder med motivation og forandringsparathed hos flygtninge med længerevarende ledighed bag sig, hvordan man kan organisere et tværfagligt samarbejde, og hvordan man kan arbejde helhedsorienteret og parallelt. 


\section{Praksiseksempel 6: Hela Familjen 2.0}

\section{Hela Familjen 2.0}

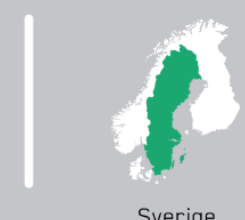

Sverige

\section{Aktører}

Malmö Kommune, Socialtjänsten i alle fem områder.

\section{Kontaktperson}

Magnus Sjöberg, projektledare, Hela Familjen 2.o, e-mail: magnus.sjoberg@malmo.se, telefon: +46708306559

Formål

At fremme beskæftigelse og forhindre fremtidige arbejdskraftrelaterede problemer og social udstødelse.

\section{Målgruppe for indsats}

Voksne i børnefamilier i Malmø, der har været på offentlig forsørgelse i mindst 24 måneder. Cirka 70 $\%$ af deltagerne kommer fra flygtningeproducerende lande. De vil have været ledige i mindst 4 år, da de 24 måneder først tæller efter den to-årige svenske integrationsperiode.

\section{Antal deltagere med traumer $\mathrm{i}$ indsats}

Det vurderes, at cirka $30 \%$ af de deltagende flygtninge har traumerelaterede problemstillinger. Det svarer til cirka 151 deltagere ud af de i alt 719 voksne i Hela Familjen 2.o.

\section{Varighed af indsats}

Den gennemsnitlige indskrivningsperiode er 18 måneder, men der er ingen tidsgrænse for varigheden af et forløb, så længe projektet varer.

\section{Baggrund og resultater}

Personalet i Hela Familjen 2.0 er kommunalt ansatte, og projektets aktiviteter er integreret i driften i Malmø Kommunes fem socialtjenester, og projektet får henvisninger direkte fra den ordinære indsats. Der er ansat 15 sagsbehandlere, som hver har 30 sager, hvilket er halvt så mange som i den ordinære indsats. En sag omfatter hele familien, og sagsbehandlerens opgave er at stå for en håndholdt og helhedsorienteret indsats i et tæt og kontinuerligt samarbejde med de voksne i familien og øvrige samarbejdspartnere omkring familien. Sagsbehandleren har både fokus på hele familien og 
de enkelte familiemedlemmer og forholder sig til alle forhold, der måtte have betydning for familiens trivsel og forældrenes mulighed for at komme i arbejde. Det kunne for eksempel være helbred, bolig, økonomi, netværk, børnenes skolegang, osv.

Hela Familjen 2.o er finansieret af Den Europæiske Socialfond og afvikles i perioden 01-01-2017 til 31-01-2019. Projektet bygger på erfaringerne fra et tidligere tre-årigt projekt, Hela Familien, som har skabt gode resultater for familier på langvarig offentlig forsørgelse. Målgruppen for Hela Familjen 2.0 er forældre i børnefamilier, der har været på offentlig forsørgelse i en længere periode, og som står uden for arbejdsmarkedet på grund af sammensatte problematikker.

Projekts mål er, at forældrene kommer i arbejde, eller, hvis ikke det lykkes, har gennemgået en proces, der har bragt dem tættere på selvforsørgelse. Succeskriteriet frem til 31-10-2018 (slutdato før forlængelse) er, at 120 ud af mindst 600 individer opnår selvforsørgelse, og at 380 kvinder og mænd er kommet tættere på selvforsørgelse. Pr. 31-102018 var der henvist 817 personer, og 197 personer ud af 315 afsluttede var kommet i henholdsvis arbejde eller uddannelse (heraf 30 i uddannelse). 328 personer ud af 471 havde halvvejs i projektet bevæget sig tættere på arbejdsmarkedet på et eller flere parametre.

I midtvejsrapporten estimeres det, at Malmø Kommune i kraft af projektet samlet set vil spare minimum 16 mio. kroner i 2018 og 2019 under forudsætning af, at projektdeltagere udsluses til beskæftigelse i samme takt som hidtil og fastholder deres selvforsørgelse i perioden. Endelige økonomiske beregninger forventes foretaget i forbindelse med projektets slutevaluering.

\section{Arbejdet med kerneelementet}

Kerneelementet i Hela Familjen 2.0 er koordination og helhedssyn. Muligheden for at bevare det helhedsorienterede blik på familien skabes ved, at sagsbehandleren har færre sager og flere ressourcer til familien. Det skaber et bedre flow $\mathrm{i}$ indsatsen, fordi problemerne bliver løst, når de bliver identificeret uden unødig ventetid på grund af travlhed hos medarbejderne.

Hovedaktiviteten i Hela Familjen 2.0 er samtale. Den første samtale bruges til at give informationer til deltageren og skabe overblik over familien, herunder antal børn, hvor de går i skole, planer for selvforsørgelse, sprogskoletilknytning, helbredsudfordringer, osv.

I det tætte samarbejde med familierne og øvrige samarbejdspartnere afdækkes forudsætninger og realistiske planer for, at forældrene kan komme i arbejde. Det fordrer en undersøgende tilgang til, hvori familiens udfordringer består, da det ikke altid er åbenlyst, hvad der egentlig er barrieren for, at forældrene kan komme i arbejde. Det samtidige fokus på alle medlemmer i familien og deres individuelle behov - og samarbejdet med relevante aktører omkring den enkelte - gør, at hvert enkelt familiemedlem flytter sig og dermed øger sine forudsætninger for at blive selvforsørgende. Det gælder 
for eksempel også børn og unge i familierne, hvis de klarer sig bedre i skolen eller kommer i gang med en uddannelse. Dermed er det ikke bare individuelle personer, men hele familier, der bringes fremad og får styrket deres ressourcer.

I komplekse tilfælde, hvor det er uklart, hvad deltageren behøver hjælp til, benyttes kortlægningsredskabet FIA (Förutsättningar Inför Arbete). I praksis gennemfører sagsbehandleren et individuelt interview med deltageren, hvor forskellige livsområder gennemgås inden for temaerne sociale forhold, mål og arbejde samt arbejdsmarkedsindsatser og krav. Forhold, der kan udgøre en forhindring for arbejde, adresseres, og sagsbehandleren laver efterfølgende en samlet bedømmelse. Den deles og drøftes med deltageren, som er med til at prioritere den fremtidige indsats. Projektet bedømmer, at det er et godt redskab til at skabe klarhed over udfordringerne med, og hvad der skal arbejdes videre med, og at det også virker godt i forhold til flygtninge. I familierne laves der et interview med både manden og kvinden, så den enkeltes støttebehov bliver afklaret. Arbejdet med FIA er så omfattende og tidskrævende, at der ikke er ressourcer til at gennemgå det med alle deltagere.

Under forløbet er der individuelle samtaler med alle mindst en gang om måneden. Her følger sagsbehandleren kontinuerligt op på forhold af betydning for deltagerens situation og de aktiviteter, familiens medlemmer i øvrigt er involveret i. Der følges konsekvent op på helbredsmæssige udfordringer, og sagsbehandleren hjælper med til, at der sker en korrekt lægefaglig vurdering, hvis ikke det er sket i forvejen. Deltagere, der er syge og ikke kan svensk, har behov for ganske meget hjælp til afklaring af diagnose og eventuelt ansøgning om førtidspension. Her kan sagsbehandleren hjælpe med til at få fat i en læge og involvere kommunens sundheds- og omsorgsforvaltning, så eventuelt behov for støtte i hjemmet kan afklares.

Børnene er en sekundær målgruppe i projektet, og sagsbehandleren spørger altid ind til dem i samtaler med forældrene. Det kan handle om skole, sundhed, fritidsaktiviteter, behov for særskilte bevillinger buskort eller udflugter og vejledning i at opsøge gratis aktiviteter for børn, hvilket der findes mange af i Malmø.

I forhold til konkrete indsatser målrettet arbejdsmarkedet kan sagsbehandleren ikke lave en indsats selv, men har en række henvisningsmuligheder. Det kan for eksempel være til Avanti (tidligere PTSD-Centret) i flygtningesager, hvor der er traumer involveret, til virksomhedspraktik, helbredsmæssig afklaring eller andet. Flygtninge vil ofte være tilknyttet sprogundervisning, inden de starter i projektet. Pointen er, at deltageren forbliver tilknyttet Hela Familjen 2.0, samtidig med de øvrige sideløbende aktiviteter - og at projektets indsats hovedsagelig består af koordination og samtaler med deltagerne.

For langtidsledige deltagere, der ikke har været i job i mange år, eller måske aldrig har været det, kan vejen til job synes lang. For at synliggøre progression for deltagerne, forsøger projektet at måle opfyldte delmål på vejen til job. Det foregår ved starten, midt i og ved afslutningen af et forløb. Målingen foretages af sagsbehandleren, der registrerer, hvorvidt deltageren har opnået en række fast definerede delmål på vejen til job. Hvis deltageren har opnået et nyt delmål siden sidste måling, er der sket en bevægelse. Ud over dokumentation bruger projektet blandt andet måleredskabet til at interessere sig yderligere for projektdeltagere, der ikke har haft nogen progression under forløbet, for at afdække mulige årsagsforklaringer. 
Projektets arbejde med hele familier har medvirket til at sætte fokus på kønsligestilling . De mandlige deltagere bruger mere tid i projektet end kvinderne, selvom der i udgangspunktet er de samme krav. Det har medført, at man nu forsøger at være mere bevidste om at have ligeværdige krav, hensyn, forventninger og opmærksomhedspunkter uanset køn. I flygtningefamilier behøver det ikke at være et problem fra et individuelt synspunkt, at en kvinde vil arbejde med børn, og en mand vil være mekaniker eller buschauffør. Men hvis det er et mønster for mange, kan det det skyldes, at de ikke ser andre muligheder og mangler viden om, hvad de ellers kunne sigte efter. Information er derfor en stor del af arbejdet, og det sker, at deltagere får øjnene op for nye muligheder (se side 56).

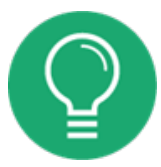

\section{Læringspunkter}

- Helhedssyn og konkrete afdækningsredskaber kan hjælpe til at finde årsager til længere tids ledighed. Herunder det konkrete redskab FIA (Förutsättningar Inför Arbete).

- Tid til at arbejde med relationer og tillid kan overvinde modstand og mistillid hos familier med mange og lange mindre gode erfaringer med systemet.

- Gennem få principper kan der, via samtaler med deltagerne, arbejdes aktivt med ligestilling, så kvinder og mænd i flygtningefamilier får ensartede krav, hensyn og tilbud.

- Tværgående koordinering og samarbejde i komplekse sager kan føre til hurtigere resultater og bedre forudsætninger for børnene fremover.

- Systematisk dokumentation af trin på vejen til arbejdsmarkedet skaber overblik over processen. 


\section{$\vee$}

Forudsætninger

- Et mindre antal sager pr. sagsbehandler, så der er tid og rum til at gå i dybden med familierne og de enkelte familiemedlemmers behov.

- Helhedssyn på familien og mulighed for at tilpasse beskæftigelsesrettede indsatser til individuelle ønsker og behov.

- Standardiserede redskaber til og procedurer for udredning og vurdering.

- Kompetencer til afdækning af problemkomplekser i samarbejde med deltagere og til at inddrage både voksne og børns synsvinkler.

- Dokumentation af processer og resultater som forudsætning for bevilling.

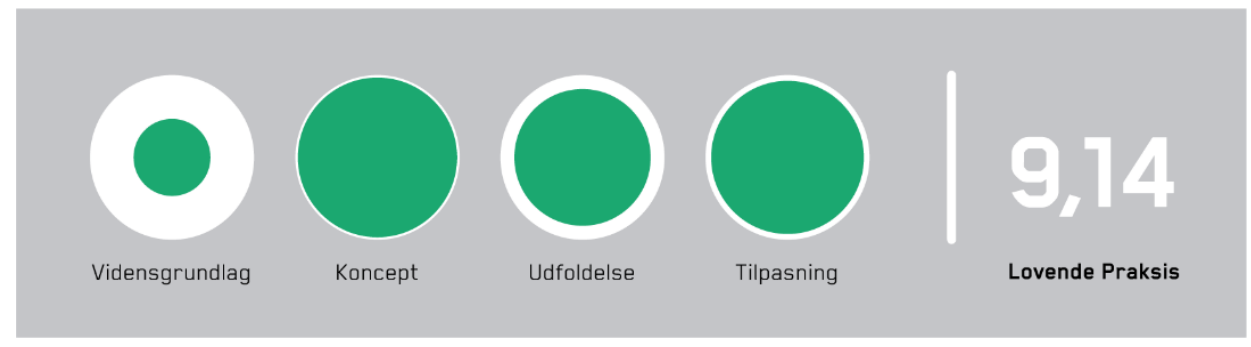




\section{Praksiseksempel 7: Avanti}

\section{Avanti}

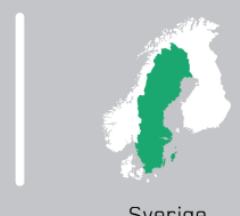

Sverige

\section{Aktører}

Malmö Stad (Malmø Kommune) projektejer, koordineringsansvar.

Komvux Södervärn - Svensk for indvandrere (Sfi). Seks sproglærere er tilknyttet.

Arbetsförmedlingen (Arbejdsformidlingen). Tre arbejdsformidlere er tilknyttet.

Röda Korset - Behandlingscenter för krigsskadade och torterade (Røde Kors); Avanti har 40 egne behandlingspladser.

Region Skåne, Flyktinghälsan. Deltager med en sygeplejerske og en læge til vejledning og

information.

\section{Kontaktperson}

Pia Werninge, arbetsmarknadssekreterare med samordningsansvar, e-mail: pia.werninge@malmo.se, telefon: +46709442605

\section{Formål}

At styrke sundhed, livskvalitet, sprogkundskaber og viden om det svenske samfund samt øge målgruppens selvforsørgelse gennem arbejde eller uddannelse.

\section{Målgruppe for indsats}

Deltagere fra 18 år og op, der er tilknyttet arbejdsformidlingen, har behov for svenskundervisning, og som - på grund af krigsrelaterede traumer og/eller migrationsrelateret stress - oplever symptomer eller har fået diagnosen PTSD.

\section{Antal deltagere med traumer $\mathrm{i}$ indsats}

102

\section{Varighed af indsats}

Man kan være indskrevet i 18 måneder med mulighed for forlængelse, hvis der er progression.

\section{Baggrund og resultater}

Avanti (PTSD-Center indtil 31-12-2017) er en helhedsorienteret og tværfaglig arbejdsmarkedsindsats i Malmø kommune for flygtninge med traumer eller migrationsrelateret stress. Indsatsen er et tilbud til ledige deltagere i målgruppen, der ikke er i stand til at deltage i den ordinære beskæftigelsesrettede indsats eller lære svensk på den sædvanlige tid. Målet med indsatsen er, at så mange deltagere som muligt kommer tættere 
på arbejdsmarkedet og får forbedret deres sundhed. Avanti har 120 pladser og knap 20 medarbejdere.

PTSD-Centret/Avanti har eksisteret siden 2012, hvor det opstod via en fusion af to forskellige rehabiliteringscentre for flygtninge. Siden årsskiftet har det primært været finansieret af Finsam (Finansiel samordning af rehabiliteringsindsatser mellem arbejdsformidling, forsikringskassen, kommune og landsting/region). Malmø Kommune er fortsat projektejer. Navneskiftet til Avanti er foranlediget af et ønske om en bredere målgruppe, end det tidligere navn signalerer. Med den nye bevilling fra 1. januar 2018 har indsatsen fået et stærkere arbejdsmarkedsfokus indholds- og personalemæssigt, omend resultatmålet er det samme.

Et af succeskriterierne er, at $40 \%$ af deltagerne afsluttes til arbejde eller studier, der berettiger til uddannelsesstøtte. Avanti ser ud til at leve op til målsætningen, idet slutrapporten for PTSD-Center 2015-2017 viser et resultat på 35 \% i arbejde og uddannelse. Endvidere viser en intern opgørelse for perioden 01-01-2018 til 12-11-2018, at 50 $\%$ er kommet i arbejde og uddannelse (38\% eksklusive dem, der modtager ordinær svensk for indvandrere-undervisning). De samlede resultater i 2018 frem til 12-11-2018 viser, at $84 \%$ blev "positivt udskrevet" til arbejde, arbejdssøgning, studier eller havde fået deres rehabiliteringsbehov klarlagt.

\section{Arbejdet med kerneelementet}

Kerneelementet i Avantis indsats er helhedssyn og tværfagligt samarbejde omkring deltagernes individuelle planer. Nøglebegreberne i virksomhedens metodik er helhedsperspektiv, parallelitet, samarbejde og arbejdslinje.

Koordination og samarbejde finder sted via samarbejdsmøder med inddragelse af alle niveauer i organisationen samt ledelsen fra de respektive samarbejdspartnere hos donor og i arbejdsformidling, region, svensk for indvandrere (SFI) og Røde Kors. Møderne styrker fælles retning, gennemsigtighed, kendskab til hinandens kompetencer og bidrager på den måde til at skabe sammenhæng i indsatsen for deltagerne. Deltagerne inddrages via et deltagerråd bestående af to deltagere fra hver klasse og to medarbejdere.

Avanti tilbyder fire parallelle spor til alle deltagere: arbejde, sprog, sundhed og behandling. Alle tilbud har til huse det samme sted, hvilket understøtter helhedsperspektivet på afgørende vis. Dels har deltagerne nem adgang til alle aktiviteter uden at skulle transportere sig fra sted til sted, og dels kan personalet samarbejde på tværs af professioner på daglig basis.

Ved opstart deltager deltageren i en eller flere vurderingssamtaler, hvor psykolog og en sagsbehandler eller jobformidler er til stede, og arbejdet med handlingsplanen påbegyndes. Ret hurtigt kobles sprog, psykoedukation og arbejdsmarkedsforløb på, så deltageren kan komme i gang med aktiviteterne, der foregår parallelt. Eventuel behandling opstartes senere. Der stilles store krav til deltagerne om, at de gennemfører 
forløbet, og at de følger med. Meget af opfølgningen foregår i grupper, hvor det tages op, hvad der fungerer godt og dårligt. I forhold til de individuelle handlingsplaner er noget af det vigtigste arbejde, der foregår, at få deltageren til at få et realistisk billede af sig selv i processen mod beskæftigelse. Her tilstræbes der en åben og ærlig kommunikation, og deltageren støttes $i$ at få splittet sit mål op i trinvise step.

Handlingsplanen laves i starten af forløbet og skal fornys i det omfang, der sker noget nyt. Ellers dokumenteres selve processen i journalen. Der arbejdes endvidere på at implementere en form for survey, som deltageren skal svare på ved forløbsstart og afslutning, og som indeholder spørgsmål vedrørende de tilbud, der arbejdes med. Store opfølgninger finder endvidere sted som minimum hver tredje måned. Generelt er der tale om en målgruppe, der har behov for at få forklaret og tydeliggjort forskellige forhold omkring tilbuddet, og som i øvrigt har behov for hjælp til mange ting. Der bruges meget tid på dialog, så deltagerne efterhånden får en bedre forståelse for processen og et ejerskab til den. Aktiviteterne reguleres af et ugeskema.

Svenskundervisningen på Avanti er tilpasset målgruppen og tager hensyn til typiske udfordringer som hukommelsesbesvær, koncentrationsproblemer og stress. Man følger den officielle læreplan, men går ikke så hurtigt frem, og der er færre kursister i klasserne end i de øvrige SFI-skoler.

De arbejdsforberedende indsatser består af arbejdsmarkedsinformation, karrierevejledning, CV-skrivning, studiebesøg i virksomheder eller besøg fra virksomheder på Avanti. Det virksomhedsrettede arbejde består af matchning og coaching, tilpasset arbejdstræning og praktik med tæt opfølgning og arbejdsgiverkontakt. De, der går ud til job, går i overvejende grad ud til støttet beskæftigelse, der er etableret som en del af indsatsen.

De rehabiliterende indsatser på sundhedsområdet består af støttesamtaler, rådgivning og vejledning, psykoedukation, sundhedsfremme og naturrehabilitering. En del af indsatsen varetages af Region Skåne. I forbindelse med den nye finansiering fra 1. januar 2018 er der dog skåret ned på aktiviteter til sundhedsfremme og naturrehabilitering til fordel for en mere arbejdsmarkedsorienteret tilgang. Behandlingsdelen bestående af psykoterapeutiske og fysioterapeutiske indsatser varetages af Røde Kors Behandlingscenter for krigsskadede og torturerede.

Avanti har 40 faste behandlingspladser på behandlingscentret. Dette rækker ikke helt, eftersom der på interviewtidspunktet var $38 \mathrm{i}$ behandling og $30 \mathrm{i}$ kø til behandling. For at øge flowet benyttes der gruppeterapi i højere grad end tidligere, og kun deltagere med behov for individuel terapi får tilbudt dette. Behandlingen foregår hos Røde Kors, men personale derfra er også synlige hos Avanti i kraft af, at de står for fysiske aktiviteter og psykoedukation. Køen til behandling er kortere for deltagere tilknyttet Avanti end for andre. Men den risikerer alligevel at skabe en ubalance i forhold til de øvrige indsatser. Psykologen på Avanti tilbyder ikke terapi, men støttesamtaler og støtter deltagerne i kontakten med forskellige myndigheder.

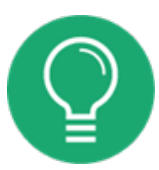




\section{Læringspunkter}

- Det tværfaglige samarbejde skal forankres på ledelsesniveau hos de aktører, der leverer personale til projektet. Det medvirker positivt til ensartede udmeldinger fra chef til medarbejdere ned gennem linjerne i de involverede organisationer, og at hver enkelt organisation påtager sig sin del af ansvaret.

- Fælles fysisk placering understøtter helhedsperspektivet $\mathrm{i}$ indsatsen og det tværfaglige samarbejde og har afgørende betydning for kvaliteten af indsatsen.

- Tæt dialog og opfølgning er afgørende for, at deltageren forstår mål og mening med processen og bliver i stand til at få ejerskab til eget forløb.

- Ekstra tid og tilpasset sprogundervisning kan på sigt føre til de samme resultater for flygtninge med traumer som i den ordinære sprogundervisning.

- Helhedsperspektivet udfordres af den lange venteliste til behandling hos Røde Kors.

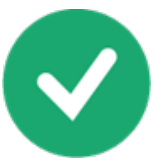

Forudsætninger

- En finansiering af indsatsen, der tager højde for, at der kan bruges den nødvendige tid på dialog, opfølgning, undervisning og aktiviteter. Et tæt og forpligtende tværgående samarbejde mellem aktørerne baseret på videndeling, ensartet kommunikation og en klar rollefordeling.

- Tæt dialog og opfølgning med deltagerne for at styrke det individuelle perspektiv, deltagerens inddragelse og ejerskab til processen samt tydeliggøre forventninger og krav.

- Kvalitativ og kvantitativ evaluering og dokumentation, som kan bidrage til at udvikle den tværfaglige indsats yderligere til gavn for målgruppen.
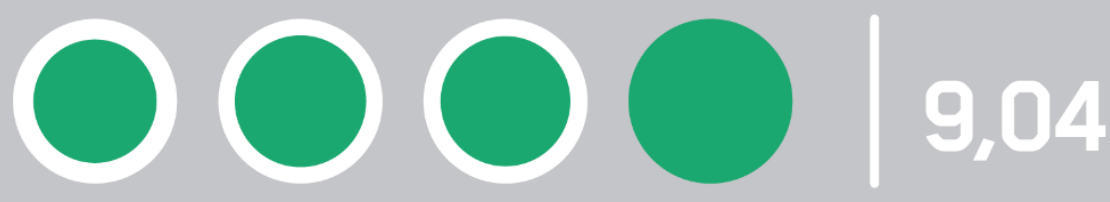


\section{Indsatser baseret på en empowerment-tilgang}

Kategorien Indsatser baseret på en empowerment-tilgang er defineret på baggrund af kerneelementer fra nedenstående indsatser og litteratur:

Tabel 8: Kategorien Indsatser baseret på en empowerment-tilgang

\begin{tabular}{lll}
\hline Kerneelement & Indsatser & Litteratur \\
\hline $\begin{array}{l}\text { Indflydelse på egne mål og planer } \\
\begin{array}{l}\text { Coaching baseret på den unges selv- } \\
\text { definerede behov }\end{array}\end{array}$ & $\begin{array}{l}\text { Norling, 2015 } \\
\text { Boll, Damgaard og Høeberg, 2014 }\end{array}$ \\
$\begin{array}{l}\text { Behov for at bygge indsats på flygt- } \\
\text { ninges egne oplevelser og selvforstå- } \\
\text { else }\end{array}$ & Eastmond, 2014 \\
$\begin{array}{l}\text { Oplevelse af, hvad empowerment } \\
\text { præges af kulturbaggrund }\end{array}$ & Pooremamali, Östman, og Eklund, \\
\hline
\end{tabular}

Kilde: Egen analyse af kerneelementer i indsatser og litteratur.

\subsection{Metoderne i Indsatser baseret på en empowerment-tilgang}

Empowerment kan beskrives både som et mål og som en proces, der gør individer og/eller grupper i stand til at handle selv, opnå deres mål og hjælpe sig selv og andre (Adams, 2008).

Empowerment er mere en måde at tænke på end en specifik metode (Andersen 2014). Det handler om at rette fokus på individers styrker og ressourcer og derigennem støtte dem til at stole på sig selv og i at handle selv. At mobilisere kraft hos grupper, der er marginaliserede i samfundet og skabe refleksion om strukturelle uligheder er også empowerment.

Metoder til at understøtte empowerment er eksempelvis coachingteknikker, hvor den, der coaches, selv er med til at definere problemstillinger og mål. Ligeværdighed i mødet er et omdrejningspunkt, da det skaber et udgangspunkt for at øge den enkeltes handlekraft.

Eftersom målet er, at deltageren bliver vafhængig af medarbejderen, er der et aktivt fokus på, at medarbejder ikke løser opgaverne for deltageren, men støtter dem i at finde og udføre løsninger selv. 


\subsection{Vidensgrundlag i litteraturstudiet for Indsatser baseret på en empowerment-tilgang}

Fire referencer i litteraturstudiet underbygger værdien af at arbejde med empowerment som tilgang over for flygtninge med traumer. Der er ingen interventionsstudier, der direkte dokumenterer beskæftigelseseffekterne af at arbejde med indsatser baseret på en empowerment-tilgang.

Empowerment betragtes i litteraturen som et redskab til at undgå klientgørelse og passivitet. Eastmond beskriver i et etnografisk studie af 300 bosniske flygtninge i Sverige, hvordan repræsentanter fra systemet gennem brugen af ordet "traume" og ved at betragte flygtningene som traumatiserede medvirker til at fratage dem handlemuligheder. Konklusionen er, at indsatserne bør beskæftige sig med flygtninges egen selvforståelse og problemdefinitioner for at modvirke klientgørelse (Eastmond, 2014).

I et kvalitativt studie af mellemøstlige migranter, der deltog i forskellige typer beskæftigelsesrettet rehabilitering, beskriver flere, at de ikke selv har været involveret $i$ at træffe beslutninger om deres beskæftigelse, hvilket giver dem en oplevelse af afmagt. Samme undersøgelse peger på, at det er nødvendigt at tilpasse forståelsen af empowerment til mennesker med mere kollektivistiske kulturelle baggrund (Pooremali, P. et al., 2015, 5.233).

Et kvalitativt studie af den specifikke intervention "Brug for Alle" dokumenterer, at inddragelse af deltagere med komplekse udfordringer kan være vanskelig, men skaber øget værdi i indsatsen blandt andet ved at medvirke til ændringer i deltagerens forløb (Boll et al., 2014). En svensk kortlægning af virkningsfulde faktorer i rehabiliteringsindsatsen for udlandsfødte fremhæver, at mulighed for indflydelse på egne mål og planer påvirker den enkeltes motivation og udvikling mod selvforsørgelse positivt (Norling, 2015).

\subsection{Eksempler på Indsatser baseret på en empowerment-tilgang}

Det er udvalgt et finsk praksiseksempel i denne kategori: "Trail of Involvement of Immigrant Youth". Indsatsen er en af mange aktiviteter i et større projekt, "VAMOS", der blandt andet er medfinansieret af den europæiske socialfond.

Resultaterne af indsatsen er gode: $54 \%$ er påbegyndt uddannelse og job efter indsatsen. Målingen af effekter er baseret på indsatsen egen opgørelse.

Praksiseksemplet er anderledes end de øvrige eksempler i publikationen, da indsatsen er baseret på frivillig deltagelse og drevet af en NGO. Der er inspiration til, hvordan man kan arbejde med en indsats, hvor deltagerne selv definerer deres udfordringer og behov for støtte. 


\section{Praksiseksempel 8: VAMOS}

\section{- Trail of Involvement of Immigrant Youth}

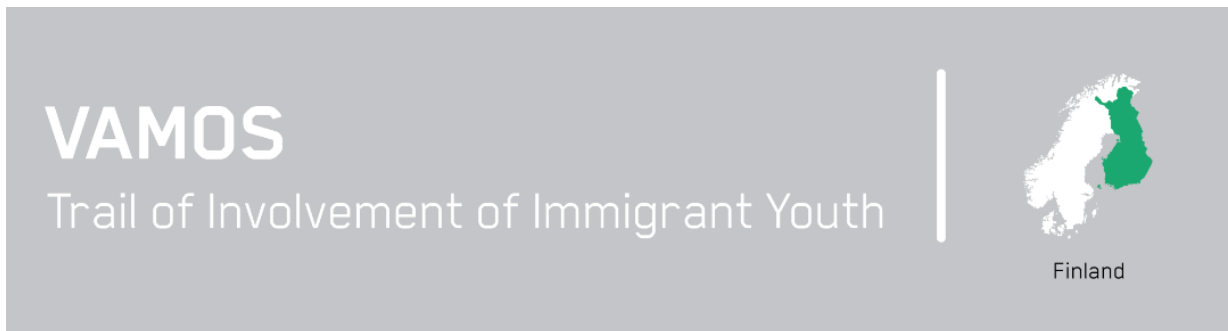

\section{Aktører}

Helsinki Deaconess Institute.

Formål

At understøtte social inklusion og vejen mod beskæftigelse, uddannelse eller andre meningsfulde aktiviteter.

\section{Målgruppe for indsats}

16-29-årige med immigrantbaggrund, som ikke er i arbejde eller uddannelse. Målgruppen omfatter nyligt ankomne, andengenerationsimmigranter og uledsagede unge.

\section{Antal deltagere med traumer $\mathrm{i}$ indsats}

I alt 300 deltager - eller har deltaget - i projektet. Det vides ikke, hvor mange af migranterne, der har flygtningebaggrund.

\section{Varighed af indsats}

Der er ingen tidsbegrænsning, men indsatsen varer typisk mindre end et halvt år. Projektet er finansieret i perioden 2016-2019.

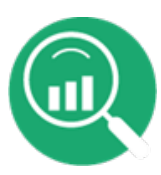

\section{Baggrund og resultater}

Trail of Involvement of Immigrant Youth er et socialfondsprojekt, som drives af Diakonisse Instituttet i Helsinki, og som har aktiviteter i Helsinki, Kuopio og Turku. Det er målrettet unge med immigrantbaggrund, der er ledige, ikke i gang med en uddannelse, eller som oplever social eksklusion. Projektets mål er at styrke de unges ressourcer og støtte dem $\mathrm{i}$ at komme i job, uddannelse eller andre relevante aktiviteter på vejen dertil.

Trail of Involvement of Immigrant Youth er en del af paraplykonceptet VAMOSindsatser for unges trivsel, som er målrettet unge, der er i fare for social eksklusion. Alle VAMOS' aktiviteter tilbyder intensiv gruppecoaching, individuel coaching og ungdomscentrerede indsatser. Indsatserne hviler på de samme principper: 1) ungdomscentreret 2) holistisk 3) samarbejdende og 4) effektfuld. Deltagelse i VAMOS-aktiviteter er frivillig, og de unge ses som aktive agenter i deres egen tilværelse. 
Unge, der henvender sig til Trail of Involvement of Immigrant Youth, får tildelt en individuel coach, der har tid til at lære dem og deres behov at kende. Det er meget forskelligt, hvad de unge søger hjælp til. Det kan for eksempel være, at de mangler en bolig, har sociale udfordringer eller går i skole og har problemer med det. En del af de unge har traumer. Coachen tilstræber at guide de unge videre til relevante indsatser og følger dem på vej, hvis der er behov for det.

Trail of Involvement of Immigrant Youth har haft tilknyttet 300 unge i alt. Af de 179 unge, der havde afsluttet et forløb inden juni 2018, var $54 \%$ kommet i uddannelse eller arbejde. På interviewtidspunktet deltog 59 i et individuelt coachingforløb, og alle var 18 år eller derover.

\section{Arbejdet med kerneelementet}

Kerneelementet i Trail of Involvement of Immigrant Youth er individuel coaching baseret på de unges selvdefinerede behov. Et forløb kan komme i stand på forskellige måder. Det kan være, at den unge selv kontakter projektet, men der kan også komme en henvendelse fra for eksempel familie, venner, skole, integrations- eller beskæftigelsesindsatser. I så fald kontakter projektet den unge og sætter et møde i stand.

Ved det første møde vil der typisk være to medarbejdere fra projektet til stede. Den unge får mulighed for at fortælle om sig selv og sit behov for hjælp, og personalet informerer om, hvad projektet kan tilbyde, herunder at de primært kan hjælpe ved at støtte og guide, ikke med at løse konkrete udfordringer for de unge.

I det videre forløb er der hovedsageligt fokus på individuel coaching, hvor fokus indledningsvist handler om at skabe tillid. Det er individuelt, hvor hyppigt møderne finder sted, men typisk én til to gange om ugen efter behov. Møderne kan afholdes hvor som helst, den unge har det godt med det. Ofte tager et forløb udgangspunkt i et konkret problem, men det sker tit, at coachen observerer, at der også er brug for noget andet, for eksempel en beskæftigelsesrettet, social eller en sundhedsfaglig indsats. I så fald guider coachen den unge det relevante sted hen. Coachen er opmærksom på ikke at gøre ting for den unge, men følger gerne med, hvis vedkommende for eksempel skal til læge. Det kan for eksempel også være en hjælp at være til stede, mens den unge selv ringer op til en kontakt. Der arbejdes således målrettet med, at de unge bliver aktive i deres egen proces og opnår selvstændighed med udgangspunkt i deres muligheder og styrker. Projektet laver sideløbende netværksarbejde med relevante serviceudbydere og bistår de unge i kontakten med dem.

Hvis målet er job, tager coachingen udgangspunkt i at få afdækket muligheder, behov, drømme og ønsker til arbejde. Mere konkret handler afklaringen om, hvorvidt den unge skal tage en uddannelse først, eller om der er andre ting, der skal løses, såsom udfordringer med bolig, helbred eller søvnforstyrrelser, inden den unge er parat til at påtage sig et arbejde. Unge, der lider af traumer, begynder typisk at åbne op for det, 
når tilliden er opbygget, og de mest presserende problemer er blevet løst. Når det sker, lytter coachen til dem og forsøger at være der for dem. Men de gør samtidig de unge opmærksomme på, at de ikke er psykologer og forsøger at guide dem det rette sted hen, hvorfra de kan blive visiteret til professionel hjælp.

Den individuelle coaching kan kombineres med gruppeaktiviteter, hvis den unge ønsker det. Det er forskelligt, hvilke gruppeaktiviteter der udbydes i de tre byer, hvor Trail of Involvement of Immigrant Youth er til stede. I Helsinki er der en åben dagligstue, hvor de unge kan møde hinanden og deltage på egne betingelser, for eksempel i finskundervisning.

Coachen forsøger at lave færre aftaler og styrke den unges kontakt til eventuelle andre indsatser, når vedkommende oplever, det er ved at lykkes, og den unge forsøger at klare sig selv. Målet er i sidste ende at understøtte den unges selvstændighed og overflødiggøre Trail of Involvement of Immigrant Youth i den unges liv. Coachen kontakter den unge tre og seks måneder efter afslutningen af et forløb for at høre, hvordan det går, og hvis der er behov, kan den unge genoptage sit forløb.

Der kræves ikke nogen bestemt uddannelse for at blive ansat som coach i Trail of Involvement of Immigrant Youth, og personalet repræsenterer mange forskellige professionelle baggrunde. Det er en vigtig kvalifikation at kunne flytte sig lidt væk fra rollen som professionel og kunne tale med de unge om almindelige dagligdagsemner. Desuden skal coachen kunne tale med de unge om alle aspekter af deres liv. Her er det vigtigt at leve op til VAMOS-principperne om ikke at vurdere de unge og give dem gode råd, men understøtte, at de selv finder en retning, og være der for dem i den tid, forløbet varer. Personalet modtager både intern og ekstern sparring og supervision regelmæssigt, men er ikke uddannet i nogen bestemt coachingmetode.

Trail of Involvement of Immigrant Youth overtager ikke sagsdokumentation andre steder fra. Det er et princip, at de unge skal få mulighed for fortælle deres egen historie og ikke være tynget af tidligere negative erfaringer med det offentlige og forskellige labels og diagnoser, de måtte have fået sat på sig fra skolen eller det offentlige system.

Projektet benytter et værktøj til at indsamle data fra de unge, når de starter og slutter et forløb (Outcomes Star). Formålet er at følge, hvordan de unge selv oplever, at deres liv har udviklet sig under forløbet. Indikatorerne handler bl.a. om trivsel, helbred og følelse af ensomhed. Det er dog ikke altid, at coachen vurderer, det vil være hensigtsmæssigt for den tillidsskabende proces at benytte redskabet i starten. Til gengæld dokumenteres møderne, og hvad de har handlet om, i en elektronisk journal. 


\section{0}

\section{Læringspunkter}

- De unge henvender sig ofte med akutte problemer, som de har brug for hjælp til at få løst. Ofte viser der sig at være underliggende sociale eller integrationsmæssige udfordringer.

- Den tillidsskabende proces, kombineret med tilbud om følgeskab til øvrige relevante aktører giver tryghed for den unge og kan medvirke til at skabe tillid til disse systemer og dermed lette vejen til uddannelse eller job.

- Den tillid, der skabes mellem coach og ung, kan danne grundlag for, at den unge åbner op for eventuelle traumer.

- Brugen af dokumentationsværktøjer, især i starten af forløbet, kan opleves kontraproduktive i forhold til den tillidsskabende proces.

\section{Forudsætninger}

- Coachen skal kunne tale med den unge om alle aspekter af livet og lytte fordomsfrit.

- Coachen skal lytte, guide og understøtte de unge i gøre tingene selv.

- Antallet af coachingsager pr. medarbejder skal holdes på et sådant niveau, at medarbejderen har den fornødne tid til at følge forløbende til dørs.

- Forløbets fokus skal være på uafhængighed og selvstændighed baseret på muligheder og styrker.

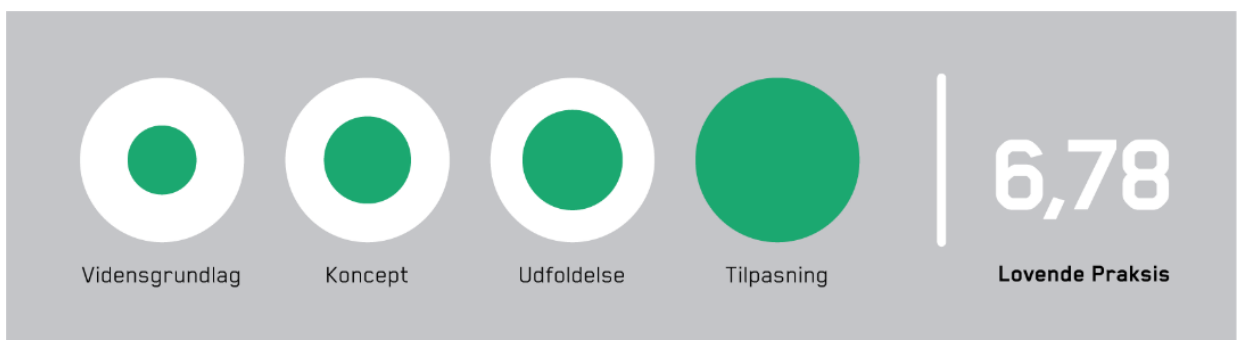




\section{Konklusion}

Det samlede vidensgrundlag om beskæftigelsesrettede indsatser for flygtninge, der er psykisk sårbare, har symptomer på traumer eller er traumatiserede, er spinkelt. Der foreligger få studier af specifikke interventioner for målgruppen og robustheden af studierne i forhold til at måle effekter er lav.

På trods af det spinkle vidensgrundlag i litteraturen viser undersøgelsen også et felt, der er i udvikling. Der er identificeret en række praksisser, der har en høj score for "Lovende praksis" og dermed god sandsynlighed for have gode beskæftigelseseffekter for målgruppen.

På baggrund af en analyse af virkningsfulde elementer (kerneelementer) i litteratur og praksiseksempler er der defineret fire kategorier af virkningsfulde indsatser. En indsats kan have elementer fra forskellige kategorier.

- Arbejde først-indsatser er baseret på metoderne Supported Employment og Individal Placement and Support. De skiller sig ud fra de øvrige indsatser ved at lægge vægt på, at deltagerne skal påbegynde ordinært arbejde/uddannelse så hurtigt som muligt og støttes sideløbende, fremfor at deltage i arbejdsforberedende indsatser. Indsatserne i kategorien arbejder mere strategisk end de øvrige med at reducere anvendelsen af praktik og bruger lige så meget tid på relationen til arbejdsgivere som til deltagerne i indsatsen.

- Grundige afdækningsindsatser bruger forskellige konkrete afdækningsredskaber og sammensatte forløb i virksomhederne til at afdække og styrke ressourcer og motivation hos deltagerne. Indsatserne har på nogle måder en mere forberedende karakter end Arbejde Først-kategorien og kan derfor også gå forud for en Arbejde først-indsats, eksempelvis hos deltagere, der mangler selvtillid og beskæftigelsesrettet motivation.

- Helhedsorienterede og tværfaglige indsatser bruger metoder til at styrke koordinationen mellem forskellige fagligheder og til at arbejde med deltagere, hvis udfordringer er komplekse. Indsatserne i kategorien arbejder med en bredspektret og koordineret støtte. Der er fokus på at se deltagerne som hele mennesker med mangeartede ressourcer og udfordringer og ikke kun at se individet, men også deres familie og netværk. Indsatserne fokuserer på, at målgruppen har behov for strukturerede og parallelle indsatser uden at skulle stå for koordinationen af indsatserne selv.

- Indsatser baseret på en empowerment-tilgang er en kategori, der mere beskriver et mindset $i$ indsatserne, hvor deltagere ses og styrkes $i$ at være handlekraftige kaptajner i eget liv. Alle praksiseksemplerne arbejder med at styrke ligeværdighed i mødet mellem medarbejdere og deltagere, men afhængig af indsatsen, 
organisatorisk forankring og målgruppens ressourcer er der i nogle tilfælde mere tale om medinddragelse end empowerment. Praksiseksemplet i denne kategori er helt rent funderet på empowerment-principper og kan derfor give inspiration til, hvordan man $\mathrm{i}$ andre typer indsatser kan arbejde med at styrke deltagernes handlekraft.

Som nævnt kan en enkelt indsats sagtens have elementer fra alle kategorier, og flere af praksiseksemplerne i undersøgelsen har elementer fra forskellige kategorier. Eksempelvis er empowerment-tilgangen et element i samtlige praksiseksempler. På nogle måder kan Helhedsorienterede og tværfaglige indsatser og Arbejde først-indsatser ses som modsætningsfyldte, idet førstnævnte fokuserer på parallelitet og sidstnævnte på arbejde som mål og middel. I praksis kan en konkret indsats sagtens tænke arbejde først og være helhedsorienteret og tværfaglig. Eksempelvis kan en indsats, der arbejder med Individual Placement and Support samarbejde med koordineret familieindsats i kommunalt regi. Den største forskel mellem de to typer indsatser er, at Arbejde Førstindsatser forudsætter, at deltagerne er motiverede for arbejde (og i hvert fald har sagt ja til at ville i beskæftigelse), hvor de Helhedsorienterede og tværfaglige indsatser kan rumme deltagere, der ikke har motivation for arbejde. En helhedsorienteret indsats som Hela Familjen 2.0 arbejder eksempelvis med at finde og styrke motivationen for selvforsørgelse.

\subsection{Forudsætninger for virksomme beskæftigelsesindsatser}

På tværs af de inkluderede studier og praksisser er der en række centrale forudsætninger, der er nødvendige at indtænke, hvis man vil lave en virkningsfuld beskæftigelsesindsats for målgruppen.

\subsubsection{Investering er nødvendig og betaler sig}

Det er nødvendigt at investere i indsatsen for traumatiserede flygtninge for at opnå resultater. Der ligger en investering ud over normalindsatsen til grund for alle de beskrevne praksiseksempler.

Flere af praksisserne har dokumenteret værdien af den ekstra investering gennem beregninger af de samfundsøkonomiske gevinster. De tilgængelige business case-beregninger viser, at det betaler sig at investere i sårbare og/eller traumatiserede flygtninge. Business case-beregningerne kan give inspiration til, hvordan man argumenterer for førstegangsinvesteringer $\mathrm{i}$ indsatserne og viser, hvad der skal til for at argumentere for at gå fra projektfase til implementering af indsatsen i driften (Amilon, 2018 og Huldt, 2017). 


\subsubsection{Nuanceret blikfor den enkeltes ressourcer}

Flere ressourcer er forudsætningen for at kunne bruge tid på individuel tilrettelæggelse af forløb og støtte. Uagtet om indsatsen hovedsageligt har fokus på arbejde først, grundig afdækning, helhedsorientering og tværfaglighed eller empowerment, går investeringen og de ekstra ressourcer til at sikre, at jobkonsulenter og/eller sagsbehandlere har lavere sagstal og mere tid til den enkelte. Praksiseksemplerne viser, hvordan ressourcetilførslen skaber mindre ventetid og mere flow i sagerne, giver tid til at få øje på ressourcer, kompetencer og motivation hos deltagere og til at lave bedre og varige match med arbejdspladser.

\subsubsection{Længerevarende indsatser og efterværn}

Ressourcer sikrer mulighed for længerevarende og kontinuerlige forløb, hvilket både praksiseksempler og litteratur i undersøgelsen underbygger, at målgruppen har behov for. Indsatserne argumenterer samstemmende for et behov for en længerevarende støtte.

De fleste af praksiseksemplerne har lange forløb og mulighed for fleksibilitet i forhold til at forlænge forløbet. I Business Training, der har et af de komparativt set kortere forløb, har midtvejsevalueringen peget på, at forløbet vil profitere af at lave et efterværn, hvilket der er givet midler til i en fortsættelse af projektet.

\subsubsection{Kompleksitet, misforståelser og grundlæggende tro på flygtningenes muligheder}

Flere af praksiseksemplerne peger på, at der er udfordringer med at afdække ressourcer og barrierer hos målgruppen i normalindsatsen. Flere af de interviewede i unders $\varnothing$ gelsen møder flygtninge, der er vurderet til at have væsentligt flere, færre eller helt andre udfordringer, end de reelt har. Det tyder på, at normalindsatsen til tider møder målgruppen uden nuanceret blik for individuelle ressourcer og udfordringer. Det er ikke muligt på baggrund af undersøgelsen at afgøre, hvad de mindre nuancerede afdækninger skyldes.

Til gengæld kan praksiseksemplerne pege på, at en forudsætning for få øje på ressourcer og muligheder er medarbejderes syn på målgruppen. Et centralt element i alle de beskrevne praksiseksempler er, at det er nødvendigt for at lykkes, at de medarbejdere, der arbejder i indsatserne, har en grundlæggende tro på, at traumatiserede flygtninge kan få et arbejde. Det er vigtigt for at evne at få øje på ressourcer og kompetencer hos den enkelte, det er vigtigt for at samarbejde med virksomheder om jobmatch, og det er vigtigt for at støtte deltagerne i indsatserne til selv at få øje på egne ressourcer i en livssituation i eksil, der kan være kompleks og vanskelig.

Praksisafdækningen underbygger dermed resultaterne af et forskningsprojekt foretaget af Væksthusets Forskningscenter, der påviste en sammenhæng mellem sagsbehandleres tro på udsatte lediges jobchancer og deltagernes faktiske beskæftigelsesomfang (Væksthusets Forskningscenter, 2017). 
Det peger på, at selvom metodisk stringens er af stor vigtighed, kan det ikke stå alene, men skal kombineres med rekruttering af medarbejdere, der tror på, at traumatiserede flygtninge har en plads på det nordiske arbejdsmarked.

\subsection{Perspektiver og mulighed for sikker viden}

Selvom vidensgrundlaget for nuværende er spinkelt, og der ikke foreligger egentlige studier af effekt, arbejder flere af undersøgelsens praksiseksempler aktivt og målrettet med at synliggøre, at investering i deres indsats betaler sig. Mange arbejder med systematisk dokumentation for deres deltageres progression mod arbejdsmarkedet og med før- og eftermålinger af deres indsats' beskæftigelsesmæssige resultater.

Endelig skiller enkelte of undersøgelsens indsatser i Arbejde først-kategorien sig ud, idet de er baseret på metoder, hvor der foreligger evidens for beskæftigelseseffekter for andre målgrupper. Arbejdet med systematisk opfølgning på metodetrofasthed $\mathrm{i}$ Supported Employment og med manualbaseret beskæftigelsesarbejde i Individual Placement and Support er nye tendenser på et fagligt område, der traditionelt lægger vægt på sagsbehandleres faglige råderum.

Arbejde først-indsatserne har vældig gode beskæftigelsesresultater sammenlignet med de øvrige indsatser. Det kan skyldes, at målgrupperne i nogle tilfælde er bedre afdækkede og har mindre komplekse problemstillinger, men taler også for relevansen af at arbejde mere stringent metodisk med målgruppen.

Et af de væsentlige greb i Arbejde først-indsatserne er fokuseret og formindsket brug af praktik. I de enkelte praksiseksempler peger erfaringerne på, at en strategi der prioriterer ordinære timer, konsekvent fokuserer på reduktion af mængden og længden af praktikforløb og forpligtende aftaler med arbejdsgivere om mulighed for ordinære ansættelser efter endt praktik giver resultater.

Det er også i Arbejde først kategorien, der er størst potentiale for at arbejde med at skabe evidens for effekten af en specifik beskæftigelsesmetode til gruppen af traumatiserede flygtninge. Her er det værd at følge med i det igangværende randomiserede kontrollerede forsøg med Supported Employment for flygtninge (med og uden traumer) i Bergen. 


\section{Referencer}

Adams, Robert (2008). Empowerment, Participation and Social Work. Red Globe Press; 4th edition

Andersen, Maja Lundemark. Empowerment i den beskæftigelsesrettede indsats. Beskæftigelsesregion Hovedstaden \& Sjælland.

Amilon, Anna (2017). IPS til flygtninge med traume-relaterede psykiske symtomer. Estimat af det for-ventede økonomiske udbytte. VIVE - Det Nationale Forsknings- og Analysecenter for Velfærd.

Boll, Joachim, Damgaard, Pia og Høeberg, Lars (2014). Brug for alle. Kvalitativ evaluering. Rambøll for Styrelsen for Arbejdsmarked og Rekruttering.

Bylin, Anna (2015): Slutrapport Förstudien "Första steget", Samordningsförbundet Sydnärke

Bylin, Anna (2017): Slutrapportering til Finsam Sydnärke Projekt Framsteget, Samordningsförbundet Sydnärke

Cheung, Maria (2018). Hur skapar vi en mer jämsälld arbetsmarknadsetablering? En studie av Arbetsförmedlingens förmedlingsverksamhet och insatser ur ett jämställdhetsperspektiv. Working Paper 2018:2. Arbetsförmedlingen.

COWI (2018): Business Training. Midtvejsevaluering. Den Europæiske Union, Den Europæiske Socialfond. Den Europæiske Fond for Regionaludvikling.

Cramer Jensen, D., Jin Pedersen, M., Hyld Pejtersen, J. og Amilon A. (2016). Indkredsning af lovende praksis på det specialiserede socialområde. København. SFI - Det Nationale Forskningscenter for Velfærd. 16:26.

Davis LL, Leon AC, Toscano R, Drebing CE, Ward LC, Parker PE, et al. (2012). A Randomized Controlled Trial of Supported Employment Among Veterans With Posttraumatic Stress Disorder. Psychiatr Serv. 2012;63(5):464-70.

Drake RE, Bond GR, Becker DR (2012). Individual Placement and Support: An Evidence-Based Approach To Supported Employment Robert E. Drake, Gary R. Bond, Deborah R. Becker: 1st ed. New York: Oxford University press

Eastmond, Maria (2014). Refugee Trauma as mobilizing metaphor: Policy and practice in the integration and care of refugees in Sweden. In: Overland, Gwynuth et al. Nordic Work with Traumatised refugees: Do We Really Care. Cambridge Scholars Publishing. 2014

Eriksson Sjöö, Tina (2014). Samverkansteam för personer med PTSD-liknande symtom. Vid Arbetdsmarknad- och vuxenutbildningsförvaltningen, Göteborg. Slutrapport. Samordningsförbundet Göteborg Nordost.

European Union of Supported Employment (2010): European Union of Supported Employment. Verktøykasse. Euopean Union of Supported Employment/Leonardo Partnership

FINSAM (2014). PTSD-Center. Rapport Juni 2014.

Frykman, Maja Povrzanovic (2012). Struggle for recognition: Bosnian refugees' employment experiences in Sweden. Refugee Survey Quarterly, 2012, vol. 31, no. 1, pp 54-79

Försäkringskassan och Arbetsförmedlingen (2016). Nyanländas rehabiliteringsbehov. Arbetssätt och verktyg för att identifiera behov och förslag till utvecklingsområden. ESF-projekt. Förstudie. 2016

Gullers group (2015). Utvärdering av Finsamprojektet PTSD-Center.

Jansson, Björn og Wiren, Mårten (2016). Utvärdering av Finsamprojektet PTSD-Center. TJP Analys och Utveckling 
Johansen A (2008). Arbejdets betydning for flygtninge med traumer. Dansk Flygtningehjælp Center for udsatte flygtninge [Internet]. 2008;26. Available from:

http://www.traume.dk/sites/default/files/styles/forskningsoversigt_med_forside_01[1].pdf

LG Insight (2013). Traumeundersøgelse. Undersøgelse af indsatsen for flygtninge med traumer i Danmark. September 2013. Social-, Børne- og Integrationsministeriet

Nationalt Netværk IPS, Danmark, Fundet den 17.10.2018 på: http://ipsworks.dk/ressourcer.html

Norling, Urban (2015). Samverkande Framgångfaktorer. Fremgångsrika insatser och organiseringar kring utlantsfödda med omfattande samordnade rehabiliteringsbehov. Föreningen NNS Rapportserie 2015:3

Nøkleby H, Blaasvær N, Berg RC (2017) Supported Employment for arbeidssøkere med bistandsbehov: en systematisk oversikt. Rapport. Oslo: Folkehelseinstituttet

Pooremamali, P., Persson, D., Östman, M. og Eklund, M. (2015) Facing Challenges during Occupation: Middle Eastern Immigrants' Paths to Occupational Well-Being in Sweden. Journal of Occupational Science, 2015, 22:2, 228-241.

Shapiro, Ditte K. (2017):Familieliv på flugt - syriske familiers oplevelser af brud og genskabelse af hverdagslivet. Ph.d.-skolen for Mennesker og Teknologi, Institut for Mennesker og Teknologi, Roskilde Universitet

Sidorchuk A., Engström K. and Johnson CM et al. (2017): Employment status and psychological distress in a population-based cross-sectional study in Sweden: the impact of migration. BMJ Open 2017;7

Simic N. (red.) (2018): Ny i Norden. Vägen till arbete. Nordiska ministerrådet.

Socialstyrelsen. 2017. "Vidensdeklaration - Socialstyrelsens Vidensdeklaration af sociale indsatser og metoder". Socialstyrelsen

Sveriges Kommuner och Landsting (2015): Hälsa i Sverige för asylsökande och nyanlända. Nationell spridning av insatser från förstudien om positiv hälsoutveckling för asylsökande och nyanlända. Slutrapport 2015

Styrelsen for International Rekruttering og Integration (2018). Sådan får de bedste kommuner flygtningekvinder i job. Kortlægning af 9 kommuners beskæftigelsesindsats målrettet nyankomne kvindelige flygtninge og kvindelige familiesammenførte til flygtninge. Udlændingeog Integrationsministeriet.

Tinghög, P., Arwidson, C. and Sigvardsdotter, E. et al. (2016): Nyanlända och asylsökande i Sverige. Et studie av psykisk ohälsa, trauma och levnadsvillkor. Röda Korsets Högskolas rapportserie 2016:1

Vilhelmsson, A., Östergren PO., Bjørngren Cuandra, Carin (2015). Hälsa i Centrum för Etableringsprocessen. Bedömning av arbets- och prestationformåga inom etableringen av nyanlända. FOU-rapport 2015. Malmö Högskola

Væksthusets Forskningscenter (2017). Sagsbehandlerens betydning for Udsatte borgeres jobchancer. Beskæftigelsesindikatorprojektet. Marts 2017. Væksthusets Forskningscenter. Fundet den 16.11.2018 på: http://vaeksthusets-forskningscenter.dk/wp-content/uploads/2017/03/Rapport_BIP_Sagsbehandlerens-betydning.pdf

Warfa et al. (2012): Migration experiences, employment status and psychological distress among Somali immigrants: a mixed-method international study. BMC Public Health, 12:749

Widerberg, Tobias (ansvarlig). Slutrapport Finsam.PTSD-Center 2015-2017. Arbetsmarknadsoch socialförvaltningen. 


\subsection{Materialer fra praksiseksempler}

\section{Arbeid fra dag én}

European Union of Supported Employment, Verktøykasse, http://www.euse.org/content/supported-employment-toolkit/EUSE-Toolkit-2010-Norwegian.pdf

\section{IPS Integration}

Swanson, Sarah J. og Becker, Deborah R. (2011): Supported employment: applying the individval placement and support (IPS) model to help clients compete in the workforce. Dartmouth PRC-Hazelden

\section{Framsteget}

Bylin, Anna (2015): Slutrapport Förstudien "Första steget", Samordningsförbundet Sydnärke Bylin, Anna (2017): Slutrapportering til Finsam Sydnärke Projekt Framsteget, Samordningsförbundet Sydnärke

DOA - Dialog om arbetsförmåga, Fundet 17.10.2018 på: https://www.arbetsterapeuterna.se/Om-forbundet/Forbundets-forlag/Dialog-om-arbetsformaga-DOA/

Huldt, Jonas (2017): Samhällsekonomisk utvärdering av projekt Framsteget. Samordningsförbundet Sydnärke. Payoff Utvärdering och Analys AB

\section{Business Training}

COWI (2018): Business Training. Midtvejsevaluering. Den Europæiske Union, Den Europæiske Socialfond. Den Europæiske Fond for Regionaludvikling.

\section{Hela Familjen 2.0}

Socialstyrelsen (2017): FIA - förutsättningar inför arbete. Manual till bedömningsmetoden. Fundet den 16.11.2018 på http://www.socialstyrelsen.se/SiteCollectionDocuments/2017-7-1-FIAintervju-omraden.pdf

Arbetsmarknads- och socialförvaltningen (2018): Slutrapport Sociala investeringsfonden - Hela Familjen

\section{Avanti}

FINSAM (2014). PTSD-Center. Rapport Juni 2014.

Gullers group (2015). Utvärdering av Finsamprojektet PTSD-Center.

Jansson, Björn og Wiren, Mårten (2016). Utvärdering av Finsamprojektet PTSD-Center. TJP Analys och Utveckling

Widerberg, Tobias (ansvarlig). Slutrapport Finsam. PTSD-Center 2015-2017. Arbetsmarknadsoch socialförvaltningen. 


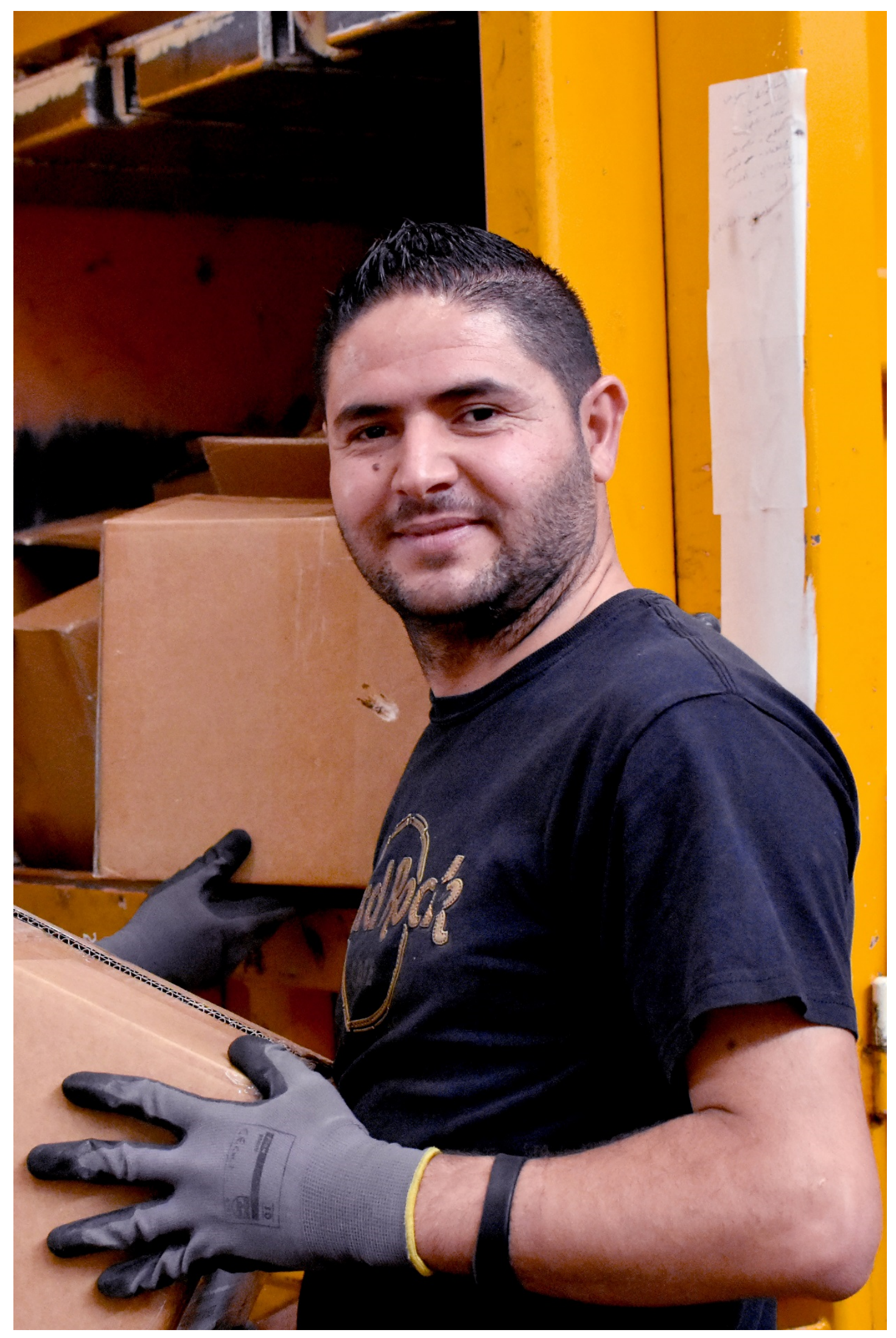




\section{English summary}

This report presents the results of a study of effective employment initiatives for refugees and reunited refugee family members who are psychologically vulnerable, have symptoms of trauma or are traumatised. The study consists of a literature study and an exploratory investigation of existing practices for the target group in Denmark, Finland, Iceland, Norway, and Sweden. The study was carried out in 2018 and includes literature from the period 2012 to 2018.

The study shows that there is a limited knowledge base about effective employment initiatives for the target group. Few studies of specific initiatives exist and the robustness of the studies in relation to measuring outcomes is low. Nevertheless, several best practices have been identified in Denmark, Finland, Norway, and Sweden that have a good probability of showing positive employment outcomes for the target group. Employees and/or managers who work with these best practices have been interviewed over several rounds. There are comprehensive descriptions of eight examples of practice in the report.

Based on the study, four categories of effective employment initiatives for the target group have been defined. The categories are defined based on the elements that have been identified as particularly effective in the literature and the practice examples. These categories are not mutually exclusive and elements from the different categories may exist side by side in a single initiative. However, there are clear differences between the main focus of the respective categories.

Work first initiatives emphasise the start of regular working hours as quickly as possible with parallel training, support, and, in some cases, treatment. Efforts are made toward a reduced and more strategic use of work placement than in the regular employment initiatives in the Nordic countries. Work first initiatives are based on the methods of Supported Employment and Individual Placement and Support, where there is a high degree of evidence of the employment effects for other target groups. The initiative is based on participants' own motivation and goals.

Vocational assessment initiatives explore the resources, challenges and motivation of participants and use the assessment as the starting point of an individually tailored process, with employment and health-oriented support. These initiatives have a holistic approach and use both specific tools and work placement for the assessment.

Holistic and interdisciplinary initiatives work with coordinated and broad-spectrum support. The initiatives in this category are often directed toward participants with complex challenges. The methods largely deal with supporting participants through labour market-oriented, healthcare and social activities running parallel to one another. The focus is structure and coordination and keeping the entire life situation of the individual in mind. 
Initiatives based on an empowerment approach are based on a mindset where participants are seen to be, and supported as, decisive actors in their own lives. Through methods such as coaching, participants are strengthened in defining their own goals and needs and in being active in relation to handling their own health and employment situation. This category also appears as a sub-element in the other categories of initiatives.

There are some key prerequisites for creating effective employment initiatives for the target group which are common to the studies and practices included in this study.

- Investment is necessary and pays off. All the examples of practice in the study were based on additional investment.

- The initiative must meet the individual needs of the participants. Individually adapted processes are possible because employees in the initiatives have fewer cases and more time available for the individual participant.

- There is a need for long-term efforts and subsequent support. The literature and practice examples illustrate the need for the process to be relatively prolonged and continuous - even after employment has been achieved.

- The work demands a fundamental belief in the potentials of the target group. Method is not everything. A key finding is that successful initiatives require employees who believe that the target group has a place in the labour market.

This study reveals an evolving field of knowledge. Several of the practice examples work actively and purposefully to highlight that investment in their initiatives bears fruit and to document their results.

The employment results for the practice examples in the Work first category are very good. This may be because the target group has less complex challenges, but it also reveals that very stringent methods with a focus on the regular job market and a reduced use of work placement may be effective. Within the Work first category there is also the potential to generate solid knowledge about the employment outcomes for the target group. Currently, there is a randomised controlled trial of the method underway for refugees (with and without trauma) in Bergen. 


\section{Bilag 1. Sådan er undersøgelsen gennemført}

Dette bilag beskriver, hvordan undersøgelsen er afgrænset og gennemført. Bilaget skal ses i sammenhæng med afsnit 3, der præsenterer undersøgelsen datagrundlag og analyse.

\section{Afgrænsninger og definitioner}

Målgruppen for undersøgelsen har baggrund som flygtninge eller familiesammenførte til flygtninge og 'er psykisk sårbare, har symptomer på traumer eller er traumatiserede'. De enkelte studier og eksempler på praksis, som indgår i undersøgelsen, kan godt have en bredere målgruppe, men ovenstående er en delmålgruppe i studierne og indsatserne, og indsatserne er bevidst tilrettelagt for også at imødekomme denne målgruppes behov.

Undersøgelsen omhandler virksomme indsatser, der har som målsætning, at målgruppen kommer i beskæftigelse eller uddannelse. Alle typer indsatser eller metoder er relevante for undersøgelsen, så længe målet med at anvende dem eksplicit er, at målgruppen kommer i beskæftigelse og uddannelse.

Undersøgelsen er afgrænset til alene at se på studier og indsatser, der er afrapporterede i perioden fra 2012 til 2018. Denne afgrænsning er lavet for at sikre, at de identificerede indsatser har fundet sted i en kontekst, der, hvad angår politiske rammer og vilkår, er sammenlignelig med forholdene nu.

Indsatsen skal være udført i Danmark, Finland, Island, Norge eller Sverige.

\section{Litteraturstudie}

Litteratursøgningen er gennemført i marts til august 2018 ud fra emneord knyttet til to facetter af undersøgelsen, nemlig

1. Målgruppen - traumatiserede og psykisk sårbare flygtninge, samt

2. Målsætningen for indsatsen, det vil sige indsatser med fokus på beskæftigelse og sekundært uddannelse.

Derudover er der anvendt søgeord for at finde litteratur om indsatser fremfor eksempelvis baggrundsanalyser. Søgningen er gennemført på engelsk, dansk, svensk og norsk. 


\section{Anvendte søgeord}

Litteraturstudiet er foretaget ud fra søgninger på baggrund af emneord illustreret i tabellen nedenfor. I søgefasen er adskillige kombinationer af søgeord blevet testet for at optimere søgningen, så alt relevant materiale kunne identificeres. På baggrund af afprøvning er det vurderet, at det ikke har været relevant at afgrænse søgningen, da mængden af undersøgelser, der omhandler beskæftigelses- eller uddannelsesrettede indsatser for sårbare og traumatiserede flygtninge, er meget begrænset. De endelige søgeord og søgestrenge er vist i nedenstående tabel.

Tabel B1: Undersøgelsens facetter og emneord på engelsk, dansk, svensk og norsk

\begin{tabular}{|c|c|c|c|c|c|}
\hline Tema & Facetter & $\begin{array}{l}\text { Engelske emne- } \\
\text { ord }\end{array}$ & $\begin{array}{l}\text { Danske emne- } \\
\text { ord }\end{array}$ & Svenske emneord & Norske emneord \\
\hline \multirow[t]{2}{*}{ Målgruppe } & \multirow[t]{2}{*}{$\begin{array}{l}\text { Traumatiserede og } \\
\text { psykisk sårbare } \\
\text { flygtninge }\end{array}$} & $\begin{array}{l}\text { Trauma } \\
\text { Vulnerable } \\
\text { PTSD }\end{array}$ & $\begin{array}{l}\text { Traume } \\
\text { Sårbar } \\
\text { PTSD }\end{array}$ & $\begin{array}{l}\text { Trauma } \\
\text { Psykiske sårbarhe- } \\
\text { der } \\
\text { Psykiske hinder } \\
\text { PTSD } \\
\text { Posttraumatisk } \\
\text { stress }\end{array}$ & $\begin{array}{l}\text { Traumer } \\
\text { Traumatisert } \\
\text { Psykiske hinder } \\
\text { Psykisk uhelse } \\
\text { PTSD } \\
\text { Posttraumatisk } \\
\text { stress }\end{array}$ \\
\hline & & Refugee & Flygtning & Flykting & Flyktning \\
\hline Outcome & $\begin{array}{l}\text { Beskæftigelse eller } \\
\text { uddannelse }\end{array}$ & $\begin{array}{l}\text { Work } \\
\text { Employment } \\
\text { Job } \\
\text { Education } \\
\text { Labor market } \\
\text { integration }\end{array}$ & $\begin{array}{l}\text { Arbejde } \\
\text { Job } \\
\text { Uddannelse } \\
\text { Beskæftigelse }\end{array}$ & $\begin{array}{l}\text { Arbet } \\
\text { Job } \\
\text { Sysselsättning } \\
\text { Utbildning } \\
\text { Arbetsmarknaden }\end{array}$ & $\begin{array}{l}\text { Yrke } \\
\text { Arbeid } \\
\text { Jobb } \\
\text { Sysselsetting } \\
\text { Okkupasjon }\end{array}$ \\
\hline Indsats & & $\begin{array}{l}\text { Methods } \\
\text { Approaches } \\
\text { Initiatives } \\
\text { Efforts } \\
\text { Intervention } \\
\text { Practice }\end{array}$ & $\begin{array}{l}\text { Metode } \\
\text { Tilgang } \\
\text { Initiativ } \\
\text { Project }\end{array}$ & $\begin{array}{l}\text { Metod } \\
\text { Tillvägagångssätt } \\
\text { Initiative } \\
\text { Projekt }\end{array}$ & $\begin{array}{l}\text { Metode } \\
\text { Innsats } \\
\text { Praksis } \\
\text { Prosjekt }\end{array}$ \\
\hline Søgestreng & & $\begin{array}{l}\text { (labo* OR job OR } \\
\text { work OR employ- } \\
\text { ment OR educa- } \\
\text { tion) AND (refu- } \\
\text { gee) AND } \\
\text { (trauma* OR vul- } \\
\text { nerable OR PTSD) } \\
\text { AND (Denmark OR } \\
\text { Sweden OR Nor- } \\
\text { way OR Finland } \\
\text { OR Iceland OR } \\
\text { Nordic) }\end{array}$ & $\begin{array}{l}\text { (metode* OR } \\
\text { tilgang* OR Ini- } \\
\text { tiativ* OR pro- } \\
\text { jekt*)" AND } \\
\text { "(traume* OR } \\
\text { sårbar* OR } \\
\text { PTSD)" AND } \\
\text { "flygtning*" } \\
\text { AND "(arbejde* } \\
\text { OR job* OR ud- } \\
\text { dannelse OR be- } \\
\text { skæftigelse*) }\end{array}$ & $\begin{array}{l}\text { (metod* OR pro- } \\
\text { jekt* OR initiativ } \\
\text { OR tillvägagångs- } \\
\text { sätt) AND (traum* } \\
\text { OR "Psykiske sår- } \\
\text { barheder" OR Psy- } \\
\text { kiske hinder OR } \\
\text { PTSD OR post- } \\
\text { traumatisk stress) } \\
\text { AND "flykting*" } \\
\text { AND (arbet* OR } \\
\text { job* OR syssel- } \\
\text { sättning* OR ut- } \\
\text { bildning OR ar- } \\
\text { betsmarknaden) }\end{array}$ & $\begin{array}{l}\text { (metode* OR } \\
\text { prosjekt* OR } \\
\text { innsats OR praksis) } \\
\text { AND (traum* OR } \\
\text { traumatisert OR } \\
\text { "Psykiske hinder" } \\
\text { OR "psykisk } \\
\text { uhelse" OR PTSD } \\
\text { OR posttraumatisk } \\
\text { stress) AND } \\
\text { "flyktning*" AND } \\
\text { (yrke OR arbeid* } \\
\text { OR jobb* OR } \\
\text { sysselsetting* OR } \\
\text { okkupasjon) }\end{array}$ \\
\hline
\end{tabular}

Kilde: Egen opgørelse. 


\section{Anvendte søgedatabaser}

Indledningsvis er søgningen ud fra ovennævnte emneord foretaget i REX og Google Scholar. Derefter er søgningerne gennemført i SCOPUS og Psyclnfo. Søgningerne i de specifikke forskningsdatabaser gav ikke noget resultat. Desuden er der gennemført en søgning i Dignitys onlinekatalog, der indeholder referencer til bøger, rapporter og artikler om tortur og relaterede emner. Søgningen i denne sammenhæng var alene på emneordet employment, da hele databasen omhandler den undersøgelsens målgruppe. Denne søgning gav resultat.

Mængden af publiceret forskningslitteratur på området er stærkt begrænset, så søgningen har også omfattet det, der kan betegnes som grå litteratur, i dette tilfælde hovedsageligt rapporter og myndighedsudgivelser. Her er der søgt generelt via Google Scholar, men også specifikt på hjemmesider for relevante myndigheder og forskningsinstitutioner i Danmark, Norge og Sverige. Derudover er der i denne søgning gjort brug af at følge citationer i allerede udvalgte publikationer. Desuden har søgningen efter eksisterende praksisser ledt til fund af evalueringsrapporter, der indgår i litteraturstudiet. Nedenfor ses en oversigt over de hjemmesider og databaser, hvor der er søgt litteratur.

\section{Tabel B2: Søgning efter grå litteratur}

\section{Land Hjemmeside/database}

Danmark Rockwoolfonden: https://www.rockwoolfonden.dk/publikationer/

Center for Boligsocial Udvikling: https://www.cfbu.dk/udgivelser/

Det Nationale Forsknings og Analysecenter for Velfærd: https://vive.dk/udgivelser/

Det Nationale Institut for Kommuners og Regioners Analyse og Forskning:

https://www.kora.dk/udgivelser/soeg-i-udgivelser/?relative $=5177 \&$ knowledgeArea $=0 \&$ author $=0$

Finland National Institute for Health and Welfare:

https://thl.fi/en/web/thlfi-en/research-and-expertwork/projects-and-programmes/previous-research-and-

projects

Norge Nasjonalt Kunnskapssenter om vold og traumatisk stress

https://www.nkvts.no/?s\&fwp_publications=other-publication $\% 2$ Cbook $\% 2$ Creport $\% 2$ Cacademic-

article\&fwp_year $=2018 \% 2 C_{2017} \%_{2} C_{2016}{ }_{2} C_{2015} \% 2 C_{2014} \% 2 C_{2013} \% 2 C_{2012} \& f w p \_p a g e d=8$

Regionalt ressurssenter om vold, traumatisk stress og selvmordsforebygging: http://rvts.no/

Fafo - Institutt for arbeidslivs- og velferdsforskning: https://www.fafo.no/index.php/forskningstema

Folkhelseinstituttet: https://fhi.no

Den Norske Arbeidsformidling: https://nav.no

Nasjonalt kompetansesenter for psykisk helsearbeid: https://www.napha.no/

Sverige FINSAM - finansiel samordning: http://www.finsam.se/publikationer/ovrigarapporter

Digitale Vetenskapliga Arkivet: http://www.diva-portal.org

Svenska ESF-rådet: https://www.ESF.se

Nordisk https://www.norden.org/da/publications

http://www.nordregio.org/publications/

Kilde: Egen opgørelse. 


\section{Omfanget af søgningen}

På baggrund af den indledende litteratursøgning blev der identificeret i alt 1668 referencer. Referencerne er fundet via systematisk søgning i Google Scholar, i Dignitys katalog, hos Nasjonalt Kunnskapssenter om vold og traumatisk stress, hos FHI og på Napha.no.

Figur B1: Oversigt over litteraturstudiet

\section{8}

Referencer identificeret

via søgedatabaser

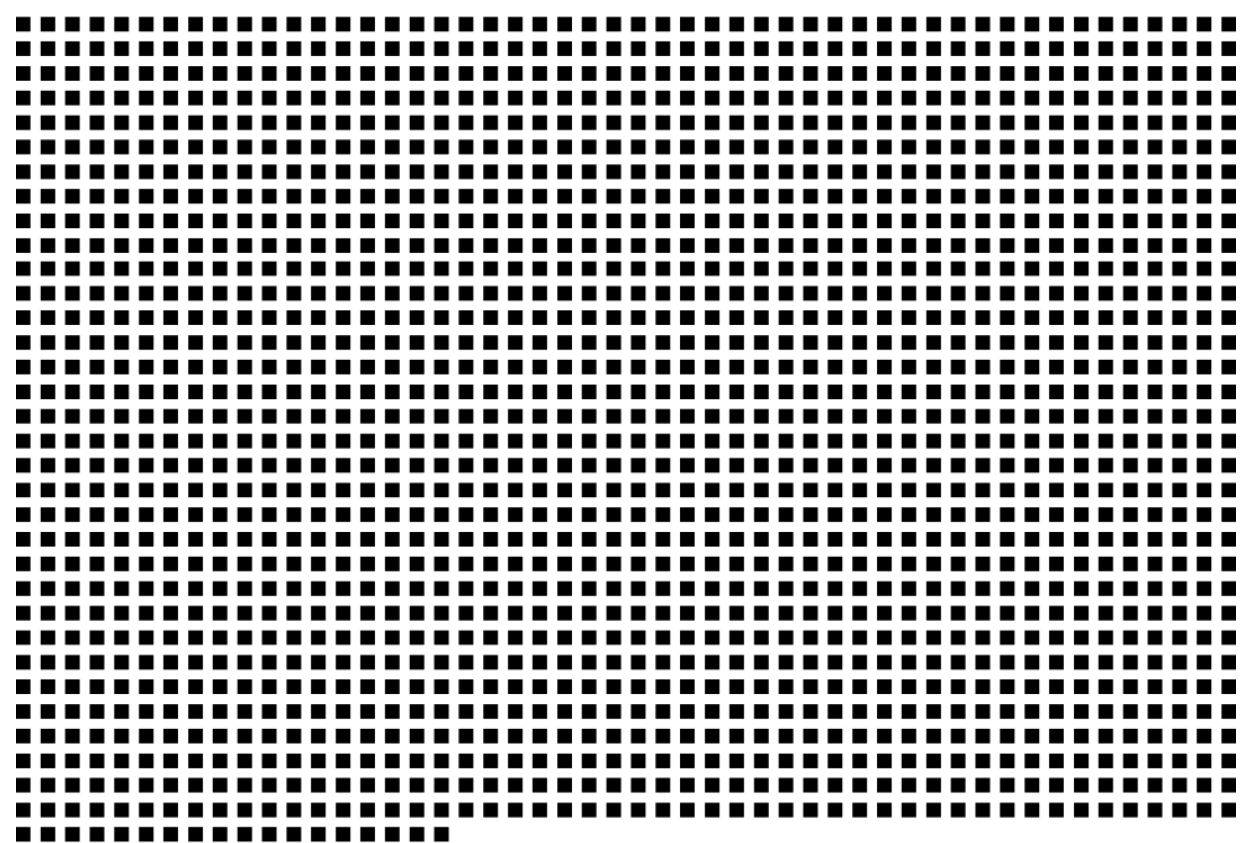

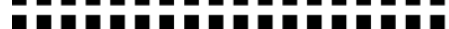

\section{9}

Referencer udvalgt på baggrund

af titel og abstract/resumé

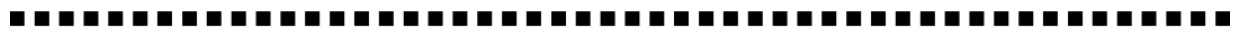

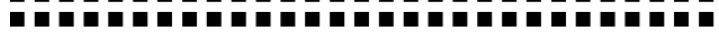

\section{6}

Referencer udvalgt

efter læsning af fuldtekst

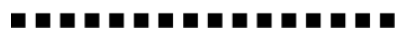

Kilde: Egen opgørelse. 


\section{Ind-og eksklusionskriterier}

Indledningsvis er alle studier, rapporter etc. blevet inkluderet, hvis de ud fra titel og resume/abstract omhandlede en relevant målgruppe, indsats og foregik i et af de deltagende nordiske lande. Det er resulteret i en bruttoliste på 79 publikationer, der efterfølgende er blevet fuldtekstlæst og vurderet i forhold til undersøgelsens fokus. Efter gennemlæsning er størstedelen af den fundne litteratur fravalgt, da den enten ikke omhandlede sårbare og traumatiserede flygtninge eller ikke lagde vægt på beskæftigelse og uddannelse som mål. Flere referencer med fokus på specifikke indsatser/projekter er fravalgt, fordi målsætninger, metode eller resultater var uklare efter fuldtekstlæsning. Der er 16 referencer, der matchede kriterierne for undersøgelsen.

\section{Udvalgt litteratur}

Ud af den samlede mængde litteratur er der udvalgt 16 tekster, heraf 10 som behandler sammenhænge mellem flygtninge med traumer og beskæftigelse, eksempelvis kvalitative studier af traumatiserede flygtninges erfaringer med beskæftigelsessystemet og beskæftigelse, men som ikke omhandler specifikke indsatser. Derudover er der 6 tekster, der omhandler interventioner med beskæftigelsesfokus for udsatte/traumatiserede flygtninge.

De 16 tekster, der indgår i litteraturstudiet, er blevet kodet med henblik på systematisk at kortlægge målgruppe, formål med indsats, delelementer $i$ indsatsen og dokumentationen for konklusioner (Se kodeskema i bilag $1 \mathrm{~A}$ ).

For de 6 studier, der beskriver specifikke interventioner for målgruppen, er robustheden af deres metoder til at dokumentere effekter vurderet på baggrund af Socialstyrelsens Vidensdeklaration: effektviden klassificering C-A. (Socialstyrelsen. 2017). Robustheden af studiernes effektmåling er blevet vurderet til $C$ i alle 6 tilfælde, da der er tale om studier, der er baseret på før- og eftermålinger, kvalitative og kvantitative opgørelser af deltagere og fagprofessionelles vurdering af effekter og virksomme mekanismer $\mathrm{i}$ indsatserne. For en oversigt over de 16 udvalgte studier, se tabel $1 \mathrm{i}$ afsnit 3 .

\section{Praksisafdækning}

Arbejdet med afdækning af eksisterende indsatser for målgruppen er baseret på litteratursøgningen og på snowball sampling via kontakter i de nordiske lande. Snowball sampling er en metode, hvor dem, man undersøger og tager kontakt til, henviser én videre til mulige kontakter i deres netværk. På den måde udvider éns kontakter i undersøgelsen sig, på samme måde som en rullende snebold vokser. Kontakterne er indledningsvis taget via referencer fra projektets styregruppe, gennem myndighedskontakter og gennem forskere på området identificeret via litteratur og fagspecifikke konferencer.

Indsatser, der kunne være relevante for undersøgelsen, er afdækket gennem tilgængelige skriftlige materialer og/eller telefoninterviews. Der har været gennemført fjorten afdækkende telefoninterviews i perioden april til august 2018, og et større antal indsatser er blevet afdækket på baggrund af skriftlige materialer. Fokus i afdækningen 
har været, om målgruppe og indsats matcher undersøgelsens formål. Ambitionen har været at finde lovende eksempler på praksis fra alle de nordiske lande, der indgår i undersøgelsen. Enkelte indsatser blev frasorteret på trods af match med undersøgelsen, fordi de endnu ikke var igangsat og dermed ikke kunne bidrage med erfaringer fra praksis. Desuden har en enkelt indsats takket nej til at deltage i undersøgelsen på grund af manglende ressourcer.

Figur B1: Oversigt over praksisafdækningen

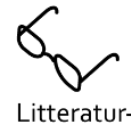

søgning
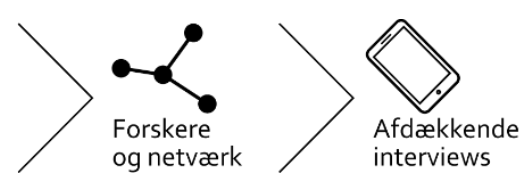
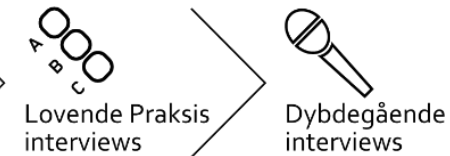

$\mathrm{Ni}$ indsatser, der matchede undersøgelsen, fik derefter tilsendt et spørgeskema, og de er efterfølgende blevet interviewet telefonisk i 1-1 $1 \frac{1}{2}$ time. Interviewet har været struktureret med spørgeskemaet som spørgeguide. Spørgeskemaet, som findes i bilag 1.B, er en engelsk udgave af måleredskabet "Lovende praksis", der er udviklet af Det Nationale Forskningscenter for Velfærd (Oversættelsen er fortaget af Center for Udsatte Flygtninge). Formålet med at anvende spørgeskemaet er at undersøge, hvor lovende indsatserne er i forhold til at opnå beskæftigelsesresultater for målgruppen (se afsnit 3).

Alle indsatserne er i det indledende interview desuden blevet spurgt til foreløbige resultater af deres indsats, og der er indhentet skriftlige materialer om indsatserne.

Derefter er ledere og/eller nøglemedarbejdere i de ni indsatser yderligere blevet interviewet i dybden om deres metode. Disse interviews er foretaget ved besøg hos indsatserne og har gennemsnitligt varet 2 timer. Interviewene ved besøgene er gennemført som semi-strukturerede interviews ud fra de 11 elementer i lovende praksis, men med fokus på at indhente fyldige beskrivelser af de elementer, indsatserne selv vurderer som centrale (se mere i afsnit 3).

En enkelt indsats er ikke beskrevet i publikationen på trods af, at der er gennemført både struktureret interview og dybdegående interview ved besøg. Indsatsen var endnu ikke fuldt implementeret, og der var derfor ikke nok erfaringer fra praksis, der kunne videreformidles.

Nedenfor ses en oversigt over de 11 elementer i "Lovende praksis". 


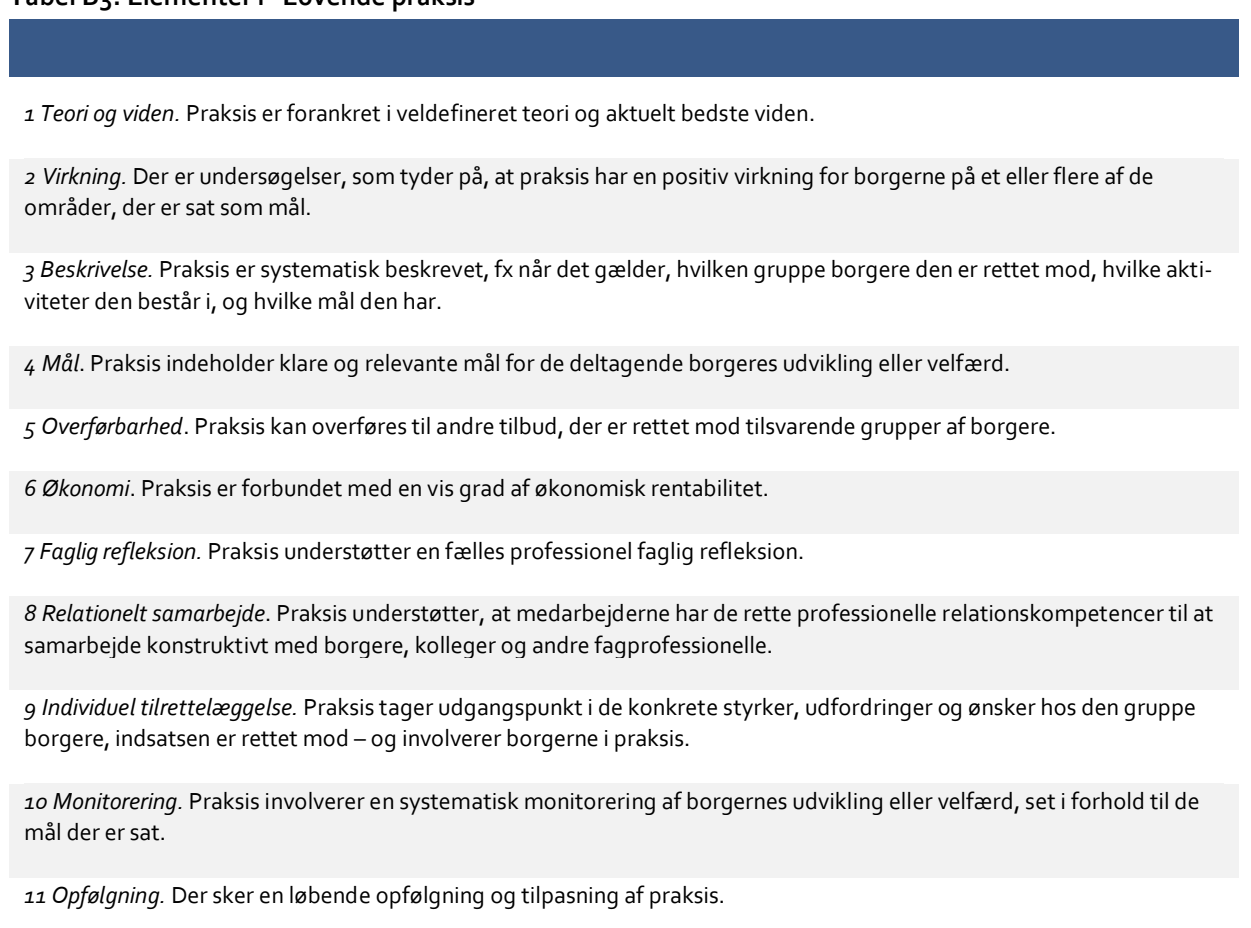

Kilde: SFI for Socialstyrelsen 2016. Kort og Klart. Lovende praksis på det specialiserede socialområde, s. 9.

\section{Analyse og identifikation af kerneelementer}

I analysen af indsatser, både fra litteraturstudiet og i praksisafdækningen, har fokus været at identificere indsatsernes kerneelementer. Kerneelementet er det delelement $\mathrm{i}$ indsatsen, der betragtes som mest afgørende for, at indsatsen har en virkning for målgruppen. Der kan være flere kerneelementer i en indsats.

De ledere og medarbejdere, der er interviewet fra indsatserne, har selv medvirket til at identificere kerneelementet eller elementerne i deres indsats og er i begge interview blevet spurgt om, hvad de selv ser som det centrale i deres tilgang.

I to af praksiseksemplerne og ét af studierne har det ikke været muligt at udskille ét kerneelement, da de har beskrevet systematiske metoder med flere trin, hvor de ikke har oplevet ét trin som mere virksomt end andre. De tre er blevet analyseret ud fra anvendelsen af den samlede metode. 


\section{Bilag 1A. Kodeskema}

Informationer om udgivelse

Fuld reference

Informatione

Metodens/indsatsens navn

Metodens/indsatsens formål

Beskrivelse af indsatsen/metoden

Kerneelement(er)

Hvilke målgrupper metoden er afprøvet i forhold til

Antal deltagere i undersøgelsen $(\mathrm{N})$

Land, hvor interventionen er udført/undersøgelsen er udført?

(Fysisk) sted hvor interventionen er udført

Metodernes effekter/virkning (hvis muligt angiv effektstør-

relse + navn på måleredskaber)

Hvilket metodisk design der ligger til grund for dokumenta-

tion af metoderne (kvalitativ undersøgelse, før/efter design,

$\mathrm{RCT})$

Vurdering af designets robusthed i forhold til at vurdere ef-

fekt (Socialstyrelsens Vidensdeklaration effektviden A-C s. 13

2017)

Realistisk at overføre den pågældende metode til en anden

national kontekst? Særlige organisatoriske/kontekstuelle for-

udsætninger/begrænsninger?

Findes en manual for metoden? (manualbaserede metoder) 


\section{Bilag 1B. Spørgeskema om "Lovende praksis"}

Spørgeskemaet er oversat til engelsk og tilpasset en beskæftigelsesrettet kontekst gennem få justeringer. Herunder udeladelsen af et enkelt spørgsmål, som specifikt var relateret til det specialiserede socialområde. Alle praksiseksemplerne i undersøgelsen har modtaget spørgeskemaet på engelsk for at sikre, at indsatserne har fået helt enslydende spørgsmål. Over telefon er spørgsmålene i nogle tilfælde blevet oversat til dansk.

\section{Introduction}

The Danish Refugee Council is conducting a study of effective employment approaches for traumatized refugees and reunified spouses and partners in the Nordic countries.

The project consists of a desk study of existing literature on effective approaches and a study of best practice used in the Nordic countries.

As part of the study of best practice we interview practitioners in the Nordic countries to get detailed information about methods and professional approaches that are successful in this field.

To do this we use a newly developed systematic method, "lovende praksis" which has been developed in Denmark and is based on a thorough research review, as well as several rounds of empirical testing. It functions as an alternative to other often timeconsuming and expensive evidence based methods, such as RCTs. The questions are designed to probe 11 separate areas, each of which being important in ensuring success for the citizens involved (additional information can be found here http://www.sfi.dk/projekter/lovende-praksis-11620).

This document includes a translation of the questions included in SFIs measurement tool for identifying "lovende praksis". The interview with practitioners on phone or SKYPE will be based on these questions.

On the basis of our first interview we might wish to visit you in order to interview you more in depth on your methods.

Practice - central methods and professional approaches

The term "practice" is used in the questionnaire. Practice is a social service/ intervention where one or more methods or professional approaches are used to achieve a professional objective.

When answering the questions you should think of your most used or most central method or professional approach.

For the purpose of our study it is useful if you think of the central practice for the target group of traumatized/vulnerable refugees. It is preferable if the practice has the goal of supporting the target group in gaining employment or education.

The results of the study will hopefully inspire further work with interventions for traumatized refugees in the Nordic countries as well as other European countries. The results from the study will be reported in the autumn 2018 in Danish and English and will be available at The Nordic Council of Ministers homepage. 


\section{Questions}

1. What is the name of your most used or most central practice in national language and translated into English
a. National language English

2. Which activities/elements does the practice consist of?

3. What is the main purpose of your practice? (We are thinking of which results you wish to accomplish by using the practice)

4. Which target group is the practice used for? (We are thinking of the target groups age, diagnosis or social challenges)

5. How many participants take part in the practice? (We are thinking of the overall number of people who at this moment in time takes part in the practice.)

If the practice is used for a broader target group than traumatized refugees, how large a group of participants suffer from trauma? (this question is added, CUF)

Questions on the theoretical approaches and knowledge behind the practice

1. Is practice based on one or more specific theories or methods? (I.e. systematic and structured approaches and/or approaches inspired by theory with a set focus and purpose).
a. No
b. Yes
c. Do not know / do not want to answer

2. Is the practice developed or recommended by experts in the field? (We think of persons external to the practice or national organizations with recognized knowledge in the field.)
a. No
b. Yes
c. Do not know / do not want to answer

3. Is the practice based on experience from your own intervention?
a. No
b. Yes
c. Do not know / do not want to answer

4. Is the practice based on experience from other national practices (regional, municipal or private)?
a. No 

b. Yes
c. Do not know/want to answer

5. Is practice based on experience from abroad?
a. No
b. Yes
c. Do not know/want to answer

6. Is there a reason why this particular practice is expected to achieve good results (theory of change)? (We think of whether there is knowledge about how the practice contributes to achieve positive results for the participants)
a. No
b. Yes
c. Do not know / do not want to answer

\section{Questions about knowledge of effects and outcomes of the practice}

1. Is the practice successful in meeting the needs of the participants? (We think of, whether or not the practice is useful for the target group that receives the service)
a. Not at all
b. To a very little extent
c. Somewhat
d. To a great extent
e. Do not know / do not want to answer

2. Is there any documented evidence that the practice works in supporting the needs of the participants?

a. Practice is very similar to another practice studied in a scientific trial (but the target group is a bit different)

b. Practice is very similar to another practice studied in a scientific trial (but the activities in the intervention are a bit different)

c. Yes, the effect is tested scientifically (By this we mean, there are studies that have shown a positive effect of practice. It will typically be the case where the effect is studied in a randomized trial (RCT) or via other methods that are well suited for effect studies)

d. Yes, they have made external investigations/evaluation

e. Yes, municipalities/organizations have gained general evidence from their own practice

f. Yes, they have made internal investigations/evaluation

g. No

h. Do not know/do not want answer 
3. Filter: If investigated externally, is the external study conducted by a University, Research institute, Consultancy firm or Local municipal consultants?
a. No
b. Yes
c. Do not know / do not want to answer

Questions about to what extent the practice is described

1. Is there a description of the practice available on a website, in an internal document or elsewhere?
d. Not at all
e. To a very little extent
f. Somewhat
g. To a great extent
h. Do not know / do not want to answer

2. Is the description so rich that other case workers/practitioners would be able to apply the practice on the basis of the description?
a. Not at all
b. To a very little extent
c. Somewhat
d. To a great extent
e. Do not know / do not want to answer

3. Is there a description of the activities/elements/actions the practice consists of?
a. Not at all
b. To a very little extent
c. Somewhat
d. To a great extent
e. Do not know / do not want to answer

4. Is there a description of the goals that practice must meet?
a. Not at all
b. To a very little extent
c. Somewhat
d. To a great extent
e. Do not know / do not want to answer

5. Is there a description of who is the target group for this practice?
a. Not at all
b. To a very little extent
c. Somewhat
d. To a great extent 


\section{e. Do not know / do not want to answer}

6. Is there a description of the needs of the target group?
a. Not at all
b. To a very little extent
c. Somewhat
d. To a great extent
e. Do not know / do not want to answer

7. Is there a description of which professional background is required in order to apply the practice?
a. Not at all
b. To a very little extent
c. Somewhat
d. To a great extent
e. Do not know / do not want to answer

8. Is there a description of how practice should be organized?
a. Not at all
b. To a very little extent
c. Somewhat
d. To a great extent
e. Do not know / do not want to answer

Questions about the objectives and goals of the practice

1. Is there a clear objective for using this practise for the target group?
a. Not at all
b. To a very little extent
c. Somewhat
d. To a great extent
e. Do not know / do not want to answer

2. Are the goals for the individual participant made specific and applicable? (We think of whether or not it is obvious what the specific goals for the participants are)
a. Not at all
b. To a very little extent
c. Somewhat
d. To a great extent
e. Do not know / do not want to answer

3. Are the goals for the individual participants clearly stated?

a. Not at all 

b. To a very little extent
c. Somewhat
d. To a great extent
e. Do not know / do not want to answer

4. Are the goals for the individual participant put into writing?
a. Not at all
b. To a very little extent
c. Somewhat
d. To a great extent
e. Do not know / do not want to answer

5. Is there a deadline (time-frame) for when the specific goal for the individual participants must be met?
a. Not at all
b. To a very little extent
c. Somewhat
d. To a great extent
e. Do not know / do not want to answer

6. Are the goals made to meet the individual and specific needs of the participants?
a. Not at all
b. To a very little extent
c. Somewhat
d. To a great extent
e. Do not know / do not want to answer

7. Are the goals formulated in such a way that it is possible to evaluate whether they have been met? (e.g. it is easier to measure whether the participants is able to catch the bus on her/his own than whether the participants has become independent in taking public transport)
a. Notatall
b. To a very little extent
c. Somewhat
d. To a great extent
e. Do not know / do not want to answer

8. Have you specified an overall goal for the group of participants who receive the practice? (an aggregated goal)
a. Not at all
b. To a very little extent
c. Somewhat
d. To a great extent 


\section{e. Do not know / do not want to answer}

Questions about whether the practice can be transferred to other settings

1. Is it possible to transfer this practice to other interventions?
a. Not at all
b. To a very little extent
c. Somewhat
d. To a great extent
e. Do not know / do not want to answer

2. Are there any specific reasons that would make it difficult for others to implement the practise in their setting? (this could be due to certain requirements about environment, locations, technology or professional skills and competences which take time to acquire)
a. Not at all
b. To a very little extent
c. Somewhat
d. To a great extent
e. Do not know / do not want to answer

Questions about the relationship between costs and benefits of the practice

3. Are you aware of the costs related to the use of practice (this includes employee time, use of technology, tools, training and other costs)
a. No
b. Yes
c. Do not know/or want to answer

4. Are the related costs justified when considering the results? (I.e. is the practise cost-efficient?)
a. No
b. Yes
c. Do not know/or want to answer

5. Are the costs of the practice compared to the costs of alternative practices which could have been applied instead?
a. No
b. Yes
c. Do not know/or want to answer 
Questions about professional reflection on the practice

1. Is it part of the practice to systematically reflect upon professional activities and actions?
a. Not at all
b. To a very little extent
c. Somewhat
d. To a great extent
e. Do not know / do not want to answer

2. Do the members of staff applying the practice receive supervision or professional coaching on the practise?
a. Not at all
b. To a very little extent
c. Somewhat
d. To a great extent
e. Do not know / do not want to answer

3. Do the members of staff have access to the latest scientific evidence and knowledge relevant for the application of this practice (e.g. through journals or newsletters)
a. Not at all
b. To a very little extent
c. Somewhat
d. To a great extent
e. Do not know / do not want to answer

4. Filter: Do the members of staff apply the newest scientific knowledge in the practise?
a. Not at all
b. To a very little extent
c. Somewhat
d. To a great extent
e. Do not know / do not want to answer

Questions on cooperation between participants and case workers and across sections and disciplines

1. Are there guidelines regarding the skills case workers require in order to work with this target group?
a. Not at all
b. To a very little extent 

c. Somewhat
d. To a great extent
e. Do not know / do not want to answer

2. Are there guidelines on how to organize cross-disciplinary and inter-disciplinary collaboration to support the practice?
a. Not at all
b. To a very little extent
c. Somewhat
d. To a great extent
e. Do not know / do not want to answer

3. Are there guidelines on how to organize cross-sectoral collaboration in order to support the practice?
a. Not at all
b. To a very little extent
c. Somewhat
d. To a great extent
e. Do not know / do not want to answer

4. Are there guidelines on how to set up collaboration with public administration in order to support the practice?
a. Not at all
b. To a very little extent
c. Somewhat
d. To a great extent
e. Do not know / do not want to answer

Questions on the involvement of the participants in the practice

1. Is practice organized on the basis of knowledge about the individual participants need for support (e.g. in the form of case files, investigations, communication between the participants and professionals)?
a. Not at all
b. To a very little extent
c. Somewhat
d. To a great extent
e. Do not know / do not want to answer

2. Is practice organized on the basis of knowledge about the participants own resources (their competences, supportive networks, etc.)?
a. Not at all
b. To a very little extent 

c. Somewhat
d. To a great extent
e. Do not know / do not want to answer

3. Are the participants or their relatives involved in the actual design and implementation of the intervention they recieve?
a. Not at all
b. To a very little extent
c. Somewhat
d. To a great extent
e. Do not know / do not want to answer

4. Does the practise support the participants feeling of "ownership" of the intervention (i.e. feel interested, empowered and responsible for the successful implementation of the intervention)?
a. Not at all
b. To a very little extent
c. Somewhat
d. To a great extent
e. Do not know / do not want to answer

5. Does the practice entail an evaluation of user satisfaction with the intervention?
a. Not at all
b. To a very little extent
c. Somewhat
d. To a great extent
e. Do not know / do not want to answer

6. Are there clear inclusion criteria for when a participant is in the target group for the practice?
a. Not at all
b. To a very little extent
c. Somewhat
d. To a great extent
e. Do not know / do not want to answer

7. Are there supportive tools available to help determine whether an individual is part of the target group for this practice? (E.g. screening criteria and tools, standardised descriptions of the target group, and/or specific assessment criteria or methods).
a. Not at all
b. To a very little extent
c. Somewhat 

d. To a great extent
e. Do not know / do not want to answer

Questions about monitoring. Do you document the progression of the participants in the practice

1. Does the practice entail a measurement of the participants development in relation to the objectives set for practice?
a. No
b. Yes
c. Do not know/do not want to answer

2. Are the participants progression/development measured over time? (By this we mean, whether you compare the participants situation before, during and after applying the practice)?
a. No
b. Yes
c. Do not know/do not want to answer

3. Is the measurement taking place according to set procedures?
a. No
b. Yes
c. Do not know/do not want to answer

4. Do you use a tool or IT system to collect documentation on the participants development?
a. No
b. Yes
c. Do not know/do not want to answer

5. Are there set procedures for how often the measurement is made?
a. No
b. Yes
c. Do not know/do not want to answer

6. Does the practise entails that outcomes for several participants are compared in order to get an overall picture of the target group's situation/development? (Aggregated data).
a. No
b. Yes
c. Do not know/do not want to answer 
7. Is the measurement of the target group's situation/development put in to a report? (Aggregated documentation).
a. No
b. Yes
c. Do not know/do not want to answer

Questions on follow-up and learning based on measurements (documentation of performance)

1. As part of the practice, are the results of the measurements made available and discussed with the participants and/or their family?
a. No
b. Yes
c. Do not know/do not want to answer

2. As part of the practise, are the results of the measurements discussed at formalized team meetings or seminars?
a. No
b. Yes
c. Do not know/do not want to answer

3. Is the intervention for the individual participant adjusted if the measurements show the need for this?
a. No
b. Yes
c. Do not know/do not want to answer

4. Are there established procedures for adjusting the intervention? (Here we think of whether the practise entails that you routinely assess whether the intervention for the individual participant should be adjusted?)
a. No
b. Yes
c. Do not know/do not want to answer

5. Is the practice adjusted if the aggregate measurements for the whole target group show the need for this?
a. No
b. Yes
c. Do not know/do not want to answer

6. Are there established procedures for adjusting the practice? (Here we think of whether you routinely asses the need for changing the practice)
a. No 

b. Yes
c. Do not know/do not want to answer

7. Are the aggregated results of the measurements for the entire target group discussed with relevant external partners?
a. No
b. Yes
c. Do not know/do not want to answer

Based on: Jensen, et al. (2016) Måleredskab til identifikation af lovende praksis.

København: SFI 


\section{Bilag 2: Beskæftigelsesindsats for flygtninge i Reykjavik, Island}

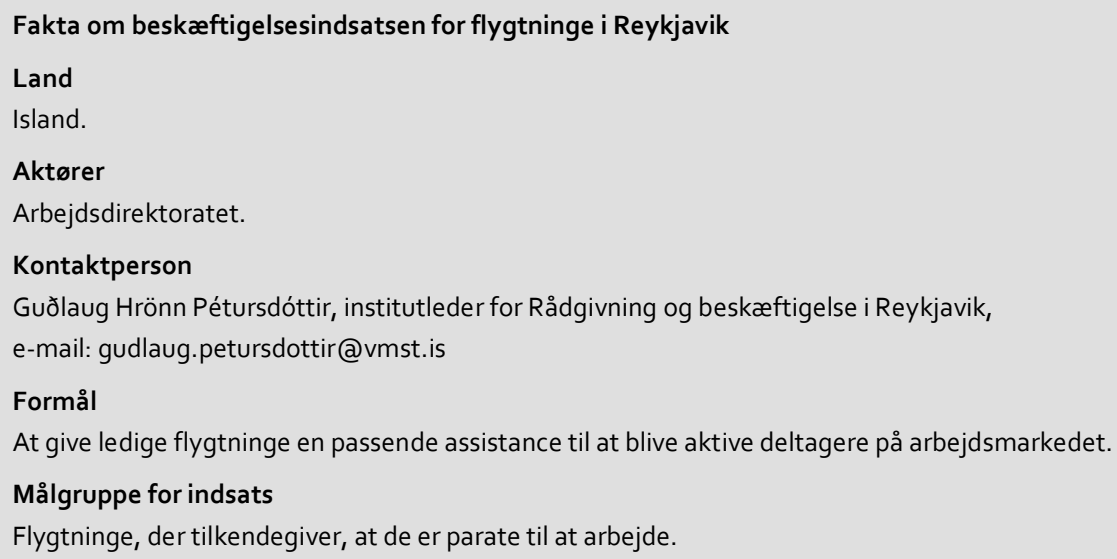

\section{Baggrund og resultater}

Det har ikke været muligt at afdække specifikke indsatser for flygtninge og familiesammenførte til flygtninge, der er psykiske sårbare, har symptomer på traumer eller er traumatiserede, på Island, hvorfor der ikke er udarbejdet en praksisbeskrivelse fra Island vedrørende arbejdet med målgruppen. I stedet gives der et kort rids over den arbejdsmarkedsrettede indsats for flygtninge i på Island med udgangspunkt i, hvordan den foregår på Arbejdsdirektoratets beskæftigelseskontor for hovedstadsområdet i Reykjavik.

Sammenlignet med de øvrige nordiske lande er der forholdsvis få flygtninge, der opnår asyl i Island. I 2016, 2017 og i de første ti måneder af 2018 har henholdsvis 111, 135 og 148 flygtninge fået en positiv afgørelse på deres asylansøgning i Island. Andelen af kvoteflygtninge er rimelig høj, idet Island modtager op til 55 i 2018. Der er stor spredning i, hvor flygtningene kommer fra. Den største andel - omkring $40 \%$ - er arabisktalende og kommer fra Irak eller Syrien.

Kvoteflygtninge i Island får tilbudt et modtagelsesprogram på et år, som varetages af kommunerne på baggrund af kontrakt med Velfærdsforvaltningen. Flygtninge, der får asyl efter at være kommet til Island på egen hånd, og familiesammenførte til flygtninge får ikke tilbudt et officielt introduktionsprogram, men henvises direkte til det relevante lokale beskæftigelseskontor under Arbejdsdirektoratet, hvis de tilkendegiver, at de er parate til at arbejde.

Flygtninge, der ikke umiddelbart er parate til at arbejde, henvises til den kommunale socialservice for at få et relevant tilbud. Det kan for eksempel være, at de ikke har 
en bolig eller har helbredsmæssige udfordringer eller er traumatiserede. Kvoteflygtninge, og flygtninge, der ikke indledningsvis er parate til arbejde, henvises til Arbejdsdirektoratet, når de er parate. Det sker typisk inden for en tidsramme på maksimalt to år. Der findes ikke specifikke rehabiliteringsprogrammer for flygtninge med traumer. Hvis det viser sig, at en flygtning er traumatiseret og har brug for behandling, men alligevel gerne vil arbejde, er der eksempler på, at vedkommende bevilges psykologhjælp ved siden af jobsøgning og arbejde.

For unge under 25 år er der et forløb, der varer 1-2 år, hvor de studerer islandsk sprog og kultur, osv. Der er eksempler på, at nogle taler flydende islandsk efter seks måneder, og dermed får lettere adgang til uddannelsessystemet.

Alle flygtninge og familiesammenførte, der har brug for sociale tilbud, kan henvende sig til den kommunale socialservice på lige fod med alle andre. Tilbuddene afhænger af deres situation og familiestatus. Alle får tilbud om rådgivning og kan ansøge om underhold, tilskud til børnene, indkøb af møbler, osv. Flygtninge, der får familiesammenføring, kan også søge om hjælp herfra. De, der har brug for det, kan få tilbud om psykologbistand.

Af de flygtninge, der i 2018 er blevet henvist til Arbejdsdirektoratets beskæftigelseskontor i Reykjavik er $53 \%$ kommet direkte fra Immigrationsdirektoratet, og $47 \%$ er kommet fra den kommunale socialservice og er dermed enten kvoteflygtninge eller øvrige flygtninge/familiesammenførte, der har haft udfordringer, der gjorde, at de ikke var parate til at arbejde fra starten. Resultaterne er gode: $73 \%$ af de flygtninge, der har deltaget i beskæftigelsesindsatsen i Reykjavik-området i perioden 2015 til 2017, er i job eller uddannelse.

\section{Det beskæftigelsesrettede arbejde}

Det er Arbejdsdirektoratets opgave at vedligeholde en liste over ledige stillinger i hele landet, at videreformidle oplysninger om ledige stillinger til jobsøgende, bistå jobs$ø$ gende i at finde job samt hjælpe arbejdsgivere med rekruttering af personale og give dem information om udbuddet af arbejdskraft. Det islandske arbejdsmarked er præget af en meget lav arbejdsløshed og en stor andel af udenlandsk arbejdskraft. Virksomhederne er generelt positive over for at tage flygtninge ind på trods af de udfordringer, der måtte være.

Flygtninge, der henvises til beskæftigelseskontoret i Reykjavik, bliver indkaldt til samtale og får tilknyttet en rådgiver. Den første samtale foregår med tolk, mens alle efterfølgende samtaler foregår på islandsk eller engelsk, eventuelt med hjælp fra Google Translate. En af rådgiverne er arabisktalende, hvilket understøtter kommunikationen med en stor del af flygtningene.

Ved det første interview gennemgås flygtningens baggrund, blandt andet tidligere uddannelses- og erhvervserfaring. Kulturelle forskelle mellem hjemlandet og Island italesættes, og der gives en række informationer om rettigheder og pligter. Det gennemgås, hvilke ledige jobs der er, og hvilke der kunne passe til den pågældende. I nogle tilfælde kontakter rådgiverne efterfølgende virksomheder fra deres netværk og præsenterer relevante kandidater for dem. Det kan så være, at virksomheden indkalder den 
eller de relevante deltagere til et jobinterview. Nogle får job allerede efter første interview, og for andre tager det længere tid. Gennemsnitligt tager det 3,5 måned fra flygtningene starter $\mathrm{i}$ indsatsen, til de har fået job.

Jobvejlederne understøtter jobsøgningsprocessen på forskellig vis. Afhængigt af den jobsøgendes individuelle behov tilbydes der rådgivning, vurdering af kvalifikationer, hjælp til CV-skrivning, gratis it-undervisning, undervisning i, hvordan det islandske system fungerer, osv. I nogle tilfælde ledsager en medarbejder flygtningen til det første jobinterview, hvor der i nogle tilfælde rekrutteres tolkebistand.

Alle får tilbud om islandskundervisning ved siden af. Det første forløb varer seks til otte uger, hvorefter det er muligt for dem, der endnu ikke har fået job, at fortsætte med to yderligere forløb. Flygtninge, der får job, mens de stadig går til sprogundervisning, kan eventuelt overflyttes til undervisning uden for arbejdstid, hvis det passer med tidspunkterne. Sproglige udfordringer i forhold til arbejdsmarkedet søges løst ved at finde arbejdspladser, der har medarbejdere med samme sproglige baggrund som flygtningen, men det lykkes ikke altid.

Rådgiverne tilbyder både mundtlig og skriftlig introduktion til virksomheder, der ansætter flygtninge. Der er lavet et skriftligt materiale om udsatte flygtninge og behandlingen af dem på arbejdspladsen, og virksomhederne får en mundtlig introduktion, når de ansætter nogen. Virksomhederne får at vide, at de altid kan henvende sig til rådgiverne, hvis der opstår problemer. I nogle tilfælde kan virksomhederne få tilbudt 75 \% løntilskud i seks måneder. Der er gode erfaringer med det, idet cirka $75 \%$ af dem, der har været i løntilskud, bliver ansat på ordinære vilkår efterfølgende.

Udsatte flygtninge får ekstra hjælp i forbindelse med jobsøgning og -start. Hvis de ikke kan sproget, kan de få en tolk med til jobinterviewet og til den første arbejdsdag, så de kan få oversat, hvad de forventes at gøre. Det er ikke noget, der sker hyppigt, men alligevel oftere nu end tidligere. Det er især sårbare kvinder, der ikke taler sproget, der har fået hjælp til det. Alle, der kommer i job, får at vide, at de altid er velkomne til at kontakte rådgiverne/jobvejlederne og bede om en samtale, hvis der opstår problemer i jobbet. 


\section{Nordisk Ministerråd \\ Nordens Hus \\ Ved Stranden 18 \\ DK-1061 København K \\ www.norden.org}

\section{Beskæftigelse og traumatiserede flygtninge}

Rapporten formidler resultaterne af en undersøgelse af virkningsfulde beskæftigelsesindsatser for flygtninge og familiesammenførte til flygtninge, der er psykisk sårbare, har symptomer på traumer eller er traumatiserede. Undersøgelsen består af et litteraturstudie og en afdækning af eksisterende praksisser for målgruppen i Danmark, Finland, Island, Norge og Sverige. Studiet viser, at vidensgrundlaget om effektive beskæftigelsesindsatser for målgruppen for nuværende er spinkelt. Alligevel er der identificeret en række lovende praksisser, der har god sandsynlighed for at have gode beskæftigelseseffekter for målgruppen. Rapporten formidler det eksisterende vidensgrundlag i litteraturen, detaljerede beskrivelser af lovende praksis og den identificerer centrale forudsætninger for at lave effektive beskæftigelsesindsatser for målgruppen. 